\title{
VYTAUTO DIDŽIOJO KARO MUZIEJUS - LIETUVOS KARINIUU TRADICIJŲ KŪRĖJAS IR KARINIO PAVELDO SAUGOTOJAS
}

\author{
Dr. Aušra Jurevičiūtè \\ Vytauto Didžiojo karo muziejus
}

Anotacija. Straipsnyje atskleidžiama, kaip Vytauto Didžiojo karo muziejus, remdamasis geriausiomis Europos muziejininkystés tradicijomis, tyre karybos istorija, rengè ekspozicijas, kürè tradicijas ir ceremonijas ir auklejjo visuomenę Tëvynès meilès dvasia. Ivertinami ir skaudūs okupaciju padariniai, išskirtinis muziejaus vaidmuo atgimimo laikotarpiu, atkuriant senąsias ir kuriant naujas tradicijas.

Pagrindiniai žodžiai: Vytauto Didžiojo karo muziejus, tradicijos, karinis paveldas, ceremonijos, ekspozicijos, okupacijos, atgimimas.

\section{IVADAS}

Švenčiant atkurtos Lietuvos valstybės ir kariuomenès 100-metị norime supažindinti su išskirtinị vaidmeni Lietuvos istorijoje vaidinusia ìstaiga - Vytauto Didžiojo karo muziejumi, kurio reikšmè țamžinant valstybès ir kariuomenès istoriją yra didžiulè ir vis dar neįvertinta. Todèl nagrinëjamoji tema yra ypač svarbi ir dabar: visos tradicijos, kurios buvo sukurtos ir atkurtos po 1990 m., taip pat viskas, kas sukaupta muziejuje, turi būti išsaugota ir kaupiama toliau, kad ateinančioms kartoms paliktume kuo turtingesnị mūsų karybos istorijos paveldą. Pirmosios Respublikos laikais sukurti ceremonialai jungia mus su praeitimi ir leidžia žengti i ateitị, remiantis geriausiai praeitị reprezentuojančiomis tradicijomis.

Tyrinejjant šią temą remtasi Lietuvos centriniame valstybès archyve ir Kauno regioniniame valstybès archyve saugomais Karo muziejaus ir su juo susijusiais dokumentais ${ }^{1}$. Dalis archyvinès medžiagos yra Vytauto

\footnotetext{
1 Vytauto Didžiojo karo muziejus, Lietuvos valstybės centrinis archyvas (toliau - LCVA), f. 1764, ap.1, f. R-423, ap. 1; Kauno regioninis valstybès archyvas (toliau - KRVA), f. 219.
} 
Didžiojo karo muziejaus rinkinių Pagalbiniame fonde. Svarbi ir įvairių laikotarpių periodinè spauda, ir amžininkų atsiminimai. Atskirų monografijų apie Vytauto Didžiojo karo muziejų ir jo veiklą nèra, tik kai kurie jo istorijos tarpsniai aprašyti JAV išleistoje knygoje, skirtoje muziejaus ¡̨kūrèjo Vlado Nagevičiaus asmenybei². Šio straipsnio autorè taip pat yra parengusi ne vieną straipsnị apie Karo muziejų 1921-1944 m., ten dirbusius karo invalidus ir brg. gen. Vladą Nagevičių ${ }^{3}$. Labai vertingi, nors gal ir subjektyvūs, tuo metu muziejuje dirbusių asmenų atsiminimai: ats. div. gen. Stasio Raštikio, dr. Broniaus Matulionio ir muziejaus viršininko ats. brg. gen. V. Nagevičiaus žmonos Veronikos Nagevičienès. Pats ats. brg. gen. V. Nagevičius atsiminimų nepaliko.

Šio straipsnio tikslas - atskleisti ir įvertinti Karo muziejaus vaidmeni kuriant Lietuvos karines tradicijas, kaupiant karinị paveldą, supažindinant su juo visuomenę ir auklejjant ją meilès savo valstybei, jos kariuomenès istorijai nuo $1921 \mathrm{~m}$. iki šių dienų dvasia. Straipsnyje tyrinèsime muziejaus ekspozicijas ir jo sukurtas žuvusių karių atminimo įamžinimo tradicijas, pagerbimo ceremonijas, būdingas tik mūsų valstybei konkrečiais istorijos tarpsniais: Pirmosios Respublikos laikais, visų okupacijų metais, atgimimo ir Lietuvos kariuomenès istorijos tradicijų atkūrimo laikotarpiu po Kovo 11-osios iki šių dienų. Atkreipsime dèmesị i kiekvieno laikotarpio iššūkius ir jų ịveikimo būdus, supažindinsime su nuostoliais, kuriuos muziejus patyrè dèl okupacijų ir kaip atgimè kartu su atgimstančia Lietuva, kokị vaidmenị suvaidino atgimimo pradžioje žadindamas tautą kaip Pirmosios Respublikos tradicijų tęsèjas.

2 Generolo gydytojo Vlado Nagiaus-Nagevičiaus gyvenimo ir darbų apžvalga. Klivlendas, 1962 .

3 Jurevičiūtè A. Senojo muziejaus istorija 1919-1930 m.,Vytauto Didžiojo karo muziejus 2006 metais, almanachas, 2007; Karo muziejaus vaidmuo kuriant švenčių tradicijas Kaune 1921-1930 m., Kauno istorijos metraštis, t. 9, Kaunas, 2008; Vytauto Didžiojo karo muziejus nacių okupacijos metais 1941-1944 m., Kauno istorijos metraštis, t. 17, Kaunas, 2016. 


\section{KARO MUZIEJAUS İKŪRIMAS IR JO VEIKLOS KONCEPCIJA 1921-1940 M.}

1918 m. vasario 16 d. paskelbus Lietuvos Nepriklausomybès Aktą, o 1919 m. kovojant su bolševikais ir bermontininkais, Lietuvos kariuomenès vadovybè, suprasdamas karo istorijos ir kiekvieno karininko ir kareivio nuopelnų Tẻvynei įamžinimo svarbą, nusprende įsteigti Karo muziejų.

1919 m. gruodžio 15 d. ịsakyme Lietuvos kariuomenei Nr. 205 buvo paskelbta: „Gydytojui pulkininkui Vladui Nagevičiui, kaipo istorijos paminklų rinkimo žinovui, pavedu imtis Krašto Apsaugos ministerijos Lietuvos karo muziejaus tvèrimo. Pavedu jam kreiptis $\mathfrak{i}$ istaigas ir asmenis, kurie šiam reikalui gali padèti. Dalių vadams ir karo komendantams įsakau teikti jam reikalingas žinias ir pagalbą. "

Tačiau 1920 m. prasidejusios žūtbūtinès Nepriklausomybės kovos su lenkais sustabde muziejaus kūrimo procesą. Šis darbas buvo pratęstas tik joms pasibaigus. $1921 \mathrm{~m}$. sausio $22 \mathrm{~d}$. buvo pasirašytas Krašto apsaugos ministerijos ịsakymas kariuomenei Nr. 17, skelbiantis, kad „steigiama nuolatine „Karo istorijos kolegija“, kuriai pavedama rūpintis taisyklingu pulkų istorijos vedimu ir Centriniu Karo muziejaus ir archyvo organizavimu“" .

I Karo istorijos kolegiją buvo paskirti gen. ltn. Maksimas Katchè, gen. ltn. Juozas Kraucevičius, gen. ltn. Valerijonas Ramanauskas, gydytojas gen. ltn. Vladas Nagevičius, plk. Juozas Litvinas, plk. ltn. Mikas Gedgaudas, plk. ltn. Arvydas Jansonas, gydytojas plk. ltn. Pranas Sližys, mjr. Leonas Šilingas, kpt. Juozas Papečkys, kpt. Vytautas Steponaitis, kpt. Jonas Laurinaitis, kpt. Antanas Užupis, kpt. Stasys Dirmantas, vyr. ltn. Jurgis Bobelis, vyr. ltn. Juozas Urbšys, veterinarijos gydytojas Kazys Trumpis, karo valdininkas Juozas Grigaitis ir Šaulių sąjungos atstovas Vladas Putvinskis. Jai pirmininkauti buvo paskirtas gen. ltn. V. Nagevičius. Komisija darbą turèjo pradèti nedelsiant. Muziejų atidaryti buvo

4 Lietuvos kariuomenei įsakymas Nr. 205, Kaunas, 1919 m. gruodžio 15 d., Rikiuotès skyrius, $\$ 21$.

5 Isakymas kariuomenei Nr. 17, Kaunas, 1921 m. sausio 22 d., Rikiuotès skyrius, $\$ 1$. 
issakyta Vasario 16-ąją - Nepriklausomybès paskelbimo dieną ${ }^{6}$.

Isakyme buvo numatyti muziejaus tikslas ir šie uždaviniai: „Lietuvos karo Muziejus turi prakilnų ir garbingą tikslą - pagaminti būsiančioms kartoms amžiną paminklą to, kaip Lietuva, per amžius priešų varginta, numetè vergijos pančius ir su ginklu rankose, per skausmus ir kovą pasiekè savo nepriklausomybę. "“7 Muziejaus ekspozicijose turèjo būti pavaizduota, kaip gimè toje pasaulio suiruteje Lietuvos kariuomenè, kaip ji augo, kovėsi ir tvarke savo kasdieni gyvenimą. „Svarbu, kad nei vienas kiek žymesnis atsitikimas pulke ar daly nepraeitų muziejaus nepastebėtas, kad kiekvieno ar tai karininko, ar kareivio tėvynei nuopelnas būtų tinkamu būdu paženklintas. " ${ }^{8}$ Tokiems dideliems ir ambicingiems tikslams igyvendinti reikejo ne tik Karo istorijos kolegijos pastangų, bet ir visų karininkų, kareivių, pagaliau visuomenès pagalbos. Todèl buvo kviečiami visi prisideti prie „bendro mūsų paminklo, Lietuvos karo muziejaus, tvėrimo"9. Buvo įsakyta visiems dalinių vadams ir kariams iki vasario $5 \mathrm{~d}$. tinkamus daiktus siųsti ị muziejų ir taip padèti Karo istorijos kolegijos nariams ir jos primininkui ji irengti.

Kuriamame muziejuje buvo numatytos šios ekspozicijos: I skyriuje (jžanginiame) - kovotojų už Lietuvos laisvę ir Nepriklausomybę galerija, senovès karų liekanų ir Lietuvos kariuomenès kūrimo iki 1918 m. lapkričio 23 d. istorijos ekspozicija (už jos įrengimą buvo atsakingi Karo istorijos kolegijos pirmininkas gen. ltn. V. Nagevičius ir jos narys kpt. Jonas Martynas Laurinitis); II skyriuje (pagrindiniame) lankytojai turèjo išvysti rikiuotès ir karinių operacijų schemas, diagramas ir piešinius, susipažinti su kariuomenès ginklavimo ir aprūpinimo istorija. Ši skyrių turèjo tvarkyti komisija, $\mathfrak{i}$ kurią buvo ịtraukti gen. ltn. M. Katchè, vyr. ltn. Juozas Urbšys (atsakingas už karinių operacijų parodymą), plk. ltn. Arvydas Jansonas (atsakingas už kariuomenės apginklavimo istoriją), vyr. ltn. Jurgis Bobelis (atsakingas už rikiuotès schemas, diagramas ir kt.), k. v. Juozas Grigaitis (atsakingas už kariuomenès aprūpinimo istoriją). Šio skyriaus pirmininku buvo paskirtas gen. ltn. M. Katchè. III skyriuje (rikiuotės da-

\footnotetext{
Ten pat, $\$ 2$.

7 Ten pat.

8 Ten pat.

9 Ten pat.
} 
lių) buvo numatyta supažindinti su Krašto apsaugos ministerija, Generaliniu štabu, péstininkų dalimis, kavalerija, karo aviacija, inžinerija ir šauliais. Už šio skyriaus ịrengimą buvo atsakinga pirmininko gen. ltn. Valerijono Ramanausko vadovaujama komisija. Jị turèjo sudaryti Generalinio štabo ir péstininkų dalių ekspozicijos (atsakingi gen. ltn. V. Ramanauskas ir kpt. Stasys Dirmantas), atsispindèti raitelių pulkų (atsakingi gen. Itn. Juozas Kraucevičius ir plk. Juozas Litvinas), artilerijos (atsakingas plk. ltn. Mikas Gedgaudas), inžinerijos (atsakingas mjr. Leonas Šilingas) ir šaulių (atsakingas Vladas Putvinskis) dalinių istorija. IV skyriuje, kurio primininku buvo paskirtas plk. ltn. Pranas Sližys, turejo būti įrengtos karo teismo (atsakingas kpt. Juozas Papečkys), sanitarijos (atsakingas plk. ltn. P. Sližys), veterinarijos (atsakingas vet. gyd. Kazys Trumpis), karo literatūros (atsakingas kpt. Vytautas Steponaitis), priešų uniformų ir ginkluotès (atsakingas kpt. Antanas Užupis) ekspozicijos. Pateikti faktai leidžia teigti, kad muziejaus ekspozicijų turinys buvo svarbus karinei vadovybei, nes jas kuriant turejjo dalyvauti ịvairių kariuomenès rūšiu karininkai.

Karo istorijos kolegija sudare komisiją, kuri turëjo parengti Kolegijos darbo taisykles, muziejaus instrukcijas, etatų sąrašą, pulkų istorijos rašymo ir centrinio archyvo darbo tvarką. I komisiją iejjo gen. ltn. M. Katchè, gen. ltn. V. Ramanauskas, gen. ltn. J. Kraucevičius, kpt. J. Papečkys, k. v. J. Grigaitis. Komisijos pirmininku buvo paskirtas k. v. J. Grigaitis, $\mathfrak{i}$ muziejaus konservatoriaus pareigas - gen. ltn. V. Nagevičius, o muziejaus saugotojų personalą buvo ịsakyta sudaryti iš karo invalidų, apdovanotų Vyčio Kryžiumi.

Rengiant muziejų susidurta su daugybe problemų, kurių negalèjo iš-

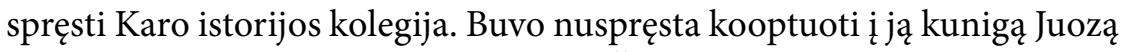
Tumą-Vaižgantą ir dailininką Antaną Žmuidzinavičių. Jie tapo muziejaus bendradarbiais ir I skyriaus ekspozicijos - „Galerijos kovotojų už Lietuvos laisvę ir Nepriklausomybę" tvarkytojais. Darbų buvo tiek daug, kad buvo ịsteigta dar ir Karo muziejaus vykdomoji komisija. Ją sudare pirmininkas kpt. Aleksandras Balsys ir nariai: inžinieriai k. v. Antanas Breimeris, kpt. Viktoras Rèklaitis ir dailininkas Petras Kalpokas. I muziejų atvežtus eksponatus buvo nutarta priimti vasario $10 \mathrm{~d}$. Butų skyriuje, kuris tuo metu buvo Vytauto pr. 59. Jiems priimti ir registruoti buvo paskirtas kpt. A. Balsys, tarnavęs muziejuje iki spalio $10 \mathrm{~d}$., kai jo pareigas 
perėmè Karo sanitarijos valdybos k. v. Petras Šeštakauskas. Nors buvo sudaryta daug komisijų, bet visas organizacinis muziejaus kūrimo darbas teko vienam žmogui - gen. ltn. V. Nagevičiui, „kuris tuo laiku tiek daug parodè veiklumo ir energijos šiame darbe, kad Karo muziejaus organizavimas ejjo milžiniškais žingsniais" ${ }^{\text {"10 }}$. Neilgai gyvavo ir Karo istorijos kolegija, kuri sugebejjo susirinkti tik ị du posėdžius, „kolegijos nariams neparodant susiinteresavimo, o iš dalies ir todèl, kad ano laiko priskirtieji kolegijon viršininkai buvo kilnojami iš Kauno ị kitas ịvairias vietas" ${ }^{\text {"11. }}$.

Muziejaus patalpoms buvo skirta sena rusų cerkvė, statyta 18841885 m., ir buvęs 111-ojo Dono pèstininkų pulko maniežas, įrengtas $1877 \mathrm{~m}$., akmeninis svirnas metaliniu stogu, pastatytas $1885 \mathrm{~m}$. Vokiečių okupacijos metais ten buvo prekių sandèlis ir automobilių garažas. Muziejų kuriant buvo svarbu ne tik surinkti eksponatus, bet ir tinkamai parengti, pritaikyti gautąji pastatą jo reikmėms. Rūpinantis apsauga, numatyta pastatą aptverti dygliuota tvora, o viduje įvesti elektrą ir sukomplektuoti gaisro gesinimo ịrangą. Paskutinėmis sausio dienomis buvo baigti tvarkyti langai, sienos, lubos. Muziejaus pastatams prižiūrèti ir ūkiui tvarkyti buvo įsteigtas komitetas. Ji sudarè inžinierius k. v. Antanas Breimeris, mjr. Leonas Šilingas ir k. v. Juozas Grigaitis. Komitetui pirmininkavo muziejaus konservatorius gen. ltn. V. Nagevičius, vadovaudamasis $1921 \mathrm{~m}$. sausio $22 \mathrm{~d}$. pirmuoju ìsakymu Karo muziejui pradejęs eiti šias pareigas.

Ekspozicijai įrengti labai trūko eksponatų, todèl buvo kreiptasi į Lietuvos žmones, kad ką nors tinkama turintys padovanotų muziejui, o jei eksponatų nenorètų palikti, leistų padaryti jų kopijas. Kai kurie daiktai buvo pasiskolinti: iš Jono Mačiulio-Maironio - Vytauto portretas, iš Liudomiro Sledzinsko - paveikslas „Kęstutis ir Biruta“, Petro Kalpoko paveikslas „Vytis“. Muziejaus vadovybė, suprasdama Nepriklausomybės kovoms j̣amžinti reikalingų eksponatų svarbą ir jų išsaugojimo būtinybę, susitelkè ì jų rinkimą kovų vietose ir jose dalyvavusiuose pulkuose. Pirmieji pulkų pateikti eksponatai buvo Nepriklausomybès kovų trofejjai - patrankos ir šautuvai: $1919 \mathrm{~m}$. iš bermontininkų atimta 3 colių rusiška ir 7,7 mm kalibro vokiška patranka, iš lenkų - prancūziška pa-

\footnotetext{
10 Akiras. Karo muziejus, Kaunas, 1930 - Vytauto Didžiojo - metai, p. 8.

11 Basanavičius J. Iš Karo muziejaus istorijos (atviras laiškas valdžios ir Seimo atstovams), Lietuva, Nr. 236, 1924 m. spalio $18 \mathrm{~d}$.
} 
tranka „Jadzė"12, Ldk Vytauto 3-iojo pėstininkų pulko dovanotas austriškas karabinas, 1919 m. liepos 21 d. ties Vaitkaičiais (Ukmergès apskr.) vyr. ltn. Prano Uoginto paimtas iš lenkų karininko, kuris ị lietuvị metè granatą, o pastarasis ji nušovè ${ }^{13}$, Ldk Mindaugo 4-ojo péstininkų pulko vado dovana - iš bolševikų karininko Ramygaloje atimtas amerikietiškas „Vinčester" sistemos šautuvas ${ }^{14}$, Margio 6-ojo pèstininkų pulko trofejjus prancūzų sistemos šautuvas, atimtas iš lenkų $1920 \mathrm{~m}$. lapkričio mènesị ${ }^{15}$. Visi šie šautuvai saugomi muziejuje iki šiol, tačiau patrankos neišliko, jos buvo sunaikintos nacistinès ir sovietinès okupacijų metais.

Iš surinktų eksponatų buvo rengiama ekspozicija: pakabintas aeroplanas ir keliasdešimt Nepriklausomybès ir kariuomenès pulkų istorinių nuotraukų. Karinius eksponatus muziejus gavo nemokamai, nes iš pradžių nebuvo finansuojamas. Aukomis ji paremè Lietuvos Respublikos prezidentas Aleksandras Stulginskis, paaukojęs 25000 auksinų, JAV lietuviai per Antaną Smetoną perdave 32000 auksinų $^{16}$. Pirmajai muziejaus ekspozicijai buvo išleista 9982 auksinai ir 90 skatikų $^{17}$. Tik $1921 \mathrm{~m}$. liepos 18 d. Ministrų Kabinetas nutare leisti Krašto apsaugos ministerijai paimti 230000 auksinų kreditą "Karo muziejui ịtaisyti ir išlaikyti 1921 m. ${ }^{\text {"18 }}$

Karo muziejaus svarbą valstybès istorijoje atkleidžia ir tas faktas, kad jo atidarymas buvo paskirtas vasario $16 \mathrm{~d}$. ir įtrauktas ị Nepriklausomybès 3-iụjų metinių minèjimo programą. Laikraštis „Lietuva“ apie Vasario 16-ąją rašè: „Kaunui pasitarimas numatė dar ypatingą šventès programą, ¡̇ kurią įeina, be iškilmingų pamaldų, parado, iliuminacijų ir t. t., dar artilerijos saliutai, prožektorių šviesa, šviesos parašai ore, plačioms minioms prieinami teatro vaidinimai, paskaitos visose miesto dalyse ir Karo muziejaus atidarymas. ${ }^{\text {19 }}$

\footnotetext{
12 Artilerijos skyriaus turto sąrašas, $L C V A$, f. 1764, ap. 1, b. 15, 1. 1.

13 Ldk Vytauto 3 p. p. padovanoto muziejui turto sąrašas, ten pat, b. 18, 1. 1.

14 Mindaugo 4 p. p. perduoto turto sąrašas, ten pat, b. 19, 1. 1.

15 Margio 6 p. p. perduoto pulko sąrašas, ten pat, b. 21, 1. 1.

16 Basanavičius J. Iš Karo muziejaus istorijos (atviras laiškas valdžios ir Seimo atstovams), Lietuva, Nr. 236, 1924 m. spalio 18 d.

17 Išlaidos muziejaus įrengimui ir išlaikymui, $L C V A$, f. 1764, ap. 1, b. 10, 1. 2.

18 Ten pat, 1. 20.

19 Dèl „16 vasario“ šventès, Lietuva, Nr. 26, 1921 m. vasario 2 d.
} 
Iškilminga muziejaus atidarymo ceremonija ịvyko $1921 \mathrm{~m}$. vasario 16 d. 15 val. Muziejų atidarè prezidentas Aleksandras Stulginskis, pašventino Jonas Mačiulis-Maironis. Iškilmèse dalyvavo Latvijos Steigiamojo Seimo delegacija: Latvijos Seimo pirmininkas A. Petrevicas (A. Petrewic), jo nariai A. Klichè (A. Klihwe) ir M. Antonas (M. Antons), Kaune rezidavusių Estijos, Italijos, D. Britanijos ir kitų užsienio misijų atstovai, Lietuvos Steigiamojo Seimo ir Vyriausybès nariai, Lietuvos kariuomenès vadas gen. Silvestras Žukauskas, visų ginklų rūšių kariuomenių, Karo mokyklos, Kauno visuomenès atstovai. Tokia gausi Latvijos delegacija atvyko todèl, kad Latvijos Respublika $1921 \mathrm{~m}$. vasario 16 d. pripažino Lietuvą de jure. Atidarymo dieną muziejuje buvo eksponuojama apie 100 ivvairių fotografijų, kelios schemos ir šiek tiek trofejų. Po iškilmingo Karo muziejaus atidarymo buvo įteikti 1-ojo laipsnio Vyčio Kryžiai karo invalidams Jurgiui Pratkevičiui, Mariui Gudaičiui, Beniui Mituzai, Jonui Rimeikiui, Felicijonui Daugvilai, Jurgiui Starkui, Antanui Veiveriui, Nikodemui Petrauskui, Jonui Kovierai, Jonui Janužiui, Jurgiui Petravičiui, Antanui Jurelioniui, Jonui Bylai, Antanui Grincevičiui, Akimui Sazonovui, Pranui Čižinauskui, Antanui Digrevičiui, Kaziui Simanavičiui, Vincui Jackevičiui ir Antanui Čepurnai, 2-ojo laipsnio - Jonui Karučiui. Kai kurie jų vèliau tarnavo Karo muziejuje.

Krašto apsaugos ministras plk. Konstantinas Žukas Karo muziejaus įsteigimą pavadino išskirtiniu to meto ịvykiu, o jo ịkūrèją gen. ltn. V. Nagevičių apibūdino taip: „Nors didelèje Muziejaus patalpoje eksponatu buvo ne per daugiausia, bet visi turejjome stebètis, ką gali padaryti vienas žmogus per tokị trumpą laiką. Kiek čia buvo energijos įdèta, kiek galvota!“ Muziejaus eksponatų fondų papildymui daug dėmesio skyrè ir pats ministras plk. K. Žukas, 1921 m. kovo 15 d. išleidęs įsakymą Vietinès brigados vadui: „Prie Karo muziejaus nuspręsta surinkti iš visos Lietuvos, iš visų mūsų praeities periodų užsilikusias patrankas, mortyras, senus ginklus ir kitas senovès karo liekanas. Prašau pavesti slapto ir griežto mano vardu visiems miestų ir apskričių komendantams įsakymo, labai skubiai, surinktas apie nurodytus daiktus žinias, visas patrankas ir kt. paimti kariuomenès ar Artilerijos skyriaus žinion. Išpildymas būtinas ir neatidèliotinas."

Ne tik ginklai buvo renkami muziejaus ekspozicijoms papildyti. Jis buvo aprūpintas ir transportu. Tiekimų skyrius kaip transportą Karo muziejui perdavė kupranugarị, atimtą iš bolševikų, ir asilą. Itvairiems 
darbams atlikti $\mathfrak{i}$ muziejų buvo komandiruojami kareiviai ir samdomi civiliniai tarnautojai, nes muziejus etatus gavo tik $1921 \mathrm{~m}$. pabaigoje. Lapkričio 18 d. Steigiamasis Seimas III skaitymu už uždarų durų patvirtino 10 laikinụjų muziejaus etatų ${ }^{20}$. Juos turèjo užimti karo invalidai, Vyčio Kryžiaus kavalieriai Antanas Sereika, Jonas Dūda, Jonas Janužis, Jonas Byla, Akymas Sazovonas, Jurgis Pratkevičius ir Jonas Karutis. 1925 m. II Seimas patvirtino 14 Karo muziejaus taikos metu etatų.

Muziejaus pastatas buvo remontuojamas ir keičiamas taip, kad atspindètų didingą Lietuvos istoriją. Šiam tikslui $1921 \mathrm{~m}$. balandžio 14 d. pagal architekto Vladimiro Dubeneckio projektą buvo perstatytas cerkvès varpinès bokštas, tapęs pilies kuoru. Ekspozicijoms taip pat buvo skiriamas išskirtinis dèmesys. Ižzanginiame skyriuje turejo būti įrengta kovotojų už Lietuvos laisvę ir nepriklausomybę galerija, o jai būtinai reikèjo portretų. Norint atlikti viską tinkamai ir profesionaliai, kreiptasi $\mathfrak{i}$ kariuomenès vadovybę, kad nuspręstų, kurių karių portretus reikia eksponuoti. Tuo tikslu sušaukta speciali komisija, vadovaujama kariuomenès vado plk. Juozo Stanaičio, nutarè: „1. Leisti išstatyti Karo muziejuje atskirus portretus visų pasižymejjusių ir žuvusių už Lietuvos laisvę; 2. Visų gyvųjų, pasižymejjusių kovose už Lietuvos nepriklausomybę; 3. Visų Krašto apsaugos ministrų, Kariuomenès vadų, Generalinio štabo viršininkų; 4. Pirmojo Karo muziejaus organizatoriaus gen. ltn. V. Nagevičiaus; 5. Pirmųjų mūsų kariuomenės vadų ir viršininkų, pradedant: rikiuotèje nuo bataliono vado imtinai, ne rikiuoteje arba įstaigoje nuo asmenų su pulko vado teisèmis imtinai; 6. Vèlesnių mūsų kariuomenès vadų ir viršininkų tokioj tvarkoj (punktas 5), bet tik po šių mirties.“ ${ }^{{ }_{21}}$

Iš to, kaip buvo kuriamas muziejus ir tikslingai renkami eksponatai, galima spręsti, kokius tikslus jis sau kèlè, kokiu tapti ir kokią idèją skleisti Lietuvai siekè. Tai buvo sprendžiama aukščiausiu lygiu, tuo rūpinosi ir krašto apsaugos ministras prof. Jonas Šimkus, kaip ir jo pirmtakai. Jis 1922 m. sausio 14 d. išleido ịsakymą Karo mokslo skyriui, kuriame pabrèžè Karo muziejaus vaidmenị, jo reikšmę lietuvių tautai ir kariuomenei: „Karo muziejus yra paminklas tai kovai, kurią Lietuvių tauta ir jos armija pakèlè ant savo pečių už Tëvynès nepriklausomybę. <...> tilpusi

20 Steigiamojo Seimo stenogramos, $1921 \mathrm{~m}$. lapkričio 18 d., I sesija, 141 posèdis, III skaitymas, Krašto apsaugos etatų svarstymas.

${ }^{21}$ Dr. Basanavičius, Iš Karo... 
Muziejuje medžiaga bus branginama ateinančių kartų ir sudarys gyvas politines ir karo tradicijas, kurios istorijos likimu kelius amžius buvo tartum nutrauktos..." ${ }^{22}$

Kariuomenè buvo tiesiogiai ịtraukta ị muziejaus kūrimą. 1922 m. vasario $6 \mathrm{~d}$. visų dalių vadams buvo įsakyta susirinkti muziejuje tolesnei jo veiklai aptarti ir atsivežti savo eksponatus pagal pridedamą sąrašą: „Dalių vadų ir pasižymėjusių karių paveikslus ir fotografijas, piešinius, raštus, ịsakymus, charakterizuojančius dalies ịsikūrimą, plètimąsi, komplektaciją, kiek tai leidžia karo paslaptis, apdovanojimus, pasižymejjimus, oficialias iškilmes ir t. t. Visa tai, kas gali charakterizuoti operaciniu atžvilgiu atliktus karo žygius, atvaizduojant ịvairiu būdu aplinkybes, kuriomis teko veikti daliai, jos laimejjimus, trofejus, nuostolius ir t. t. Kasdieninio dalies gyvenimo ir darbo charakteristika (fotografijos, paveikslai): užsièmimai, gimnastika, žaislai ir kiti vaizdai, laikraščiai, dienynai, kareivių išdirbimai. " ${ }^{23}$

Dalių delegacijų suvažiavime buvo apsvarstytas Karo muziejaus organizatoriaus pranešimas apie atliktus darbus ir tolesnius uždavinius. Žodị tarè ir 32 delegatai, jie papasakojo apie karo istorijos medžiagos rinkimą dalyse ir teikimą jos Karo muziejui. Buvo nutarta: „Karo istorijai medžiagos rinkimą vietoj suvažiavimas norètų pavesti dalių švietimo komisijoms, kooptuojant tam tikra tvarka atatinkamus asmenis. Trūkstant ekonominių sumų ir esant labai maža kitų šaltinių, suvažiavimas prašo surasti galimybes atleisti dalims nors nedideles sumas fotografijų, paveikslų, modelių dirbinių ir kitų eksponatų gaminimui. Dalyse, neturint fotografo ar esant nepakankamai savo darbą žinantiems, suvažiavimas randa reikalinga turèti kariuomenej j nors vieną, bet labai gerą fotografą. " ${ }^{24}$

Taip pat buvo išsakyti pageidavimai ir sumanymai, susiję su Lietuvos karo ir lietuvių tautos atgijimo istorija. Suvažiavime buvo nuspręsta „Karo muziejaus plètotej vadovautis tuo pačiu, ką ir pirmiau, principu: „Lietuvos Karo Muziejus yra Lietuvos Laisvės Muziejus. Muziejus privalo visą atvaizduoti, kas istorijos eigoj nuo žilos senovès pradedant iki mūsų dienų buvo atlikta lietuvių tautos gyvybei, kultūrai ir laisvei apsaugoti. Karo Muziejui turi būti kuriama dèl Lietuvos laisvès kovotojų galerija ir surinkti paveikslai, ar jų kopijos (kieno piešti ir kieno rankose jie nebū-

22 Isakymas kariuomenei Nr. 10, Kaunas, 1922 m. vasario 14 d., Karo mokslo skyrius.

23 Ten pat.

24 Ten pat. 
tų), kuriuose atvaizdinama Lietuvos istorija. Greta to uždavinio Muziejuje privalo būti uoliai renkama medžiaga, reikalinga karo mokslui ir tą mokslą einantiems. “25

Suvažiavimo delegatai, norèdami padèti Karo muziejaus organizatoriui atlikti tolesnius jo kūrimo darbus, nusprendè sudaryti trijų asmenų kolegiją ir pirmininkauti jai paskirti gen. ltn. V. Nagevičių. I šią kolegiją nutarta įtraukti istorijos žinovą ir dailininką. Kandidatais tapo kpt. Vaclovas Biržiška ir dailininkas Adomas Varnas. Susirinkusieji diskutavo ir apie aikštės prie Karo muziejaus paskirtị, jos sutvarkymo perspektyvas. Buvo nuspręsta „aikštę, prie kurios stovi Karo Muziejus su Žuvusiųjų už Lietuvos laisvę paminklu ir Laisvės varpu vietoj Arklių rinkos, pavadinti Laisvès aikšte “"26.

Suvažiavimo dalyviai svarste iškilių ir nusipelniusių Lietuvai ir jos istorijai asmenybių i̇amžinimo klausimus. Buvo nutarta „J. Basanavičiaus pagerbimui, visą ilgą amžių stovejusio Lietuvos tautos atgimimo sargyboj, ir paminèjimui kareivio Eimučio, pačioj kariuomenès steigimo pradžioje herojiškai žuvusio sargybinio pareigas einant - pastatyti dabar, žiūrint galimybes, nors bronzinius biustus Laisvès alejos sodnely komendantūros prieky. Pirmųjų nukautų kovoj karininko ir kareivio paminejjimui, jų vardais pavadinti gatves, einančias kryptimi, kur juodu žuvo: Didžiąją Šančių (Alytaus link) - pavadinti karininko Juozapavičiaus prospektu; Ukmergès gatvę (Kèdainių link) - pavadinti Lukšio gatve. Didžioji Šančių gatvė eina kareivinių rajone ir pirmo žuvusio karininko vardas tuo būdu liks tarpe jų gyvas. Paminejjimui ir pagerbimui mūsų Valstybès atgijimo svarbių dienų: Steigiamojo Seimo sušaukimo ir kariuomenès ịkūrimo - esant galimybei, ąžuolų kalne pastatyti akmenini monumentą arba nors ir akmens stulpą su atitinkamais parašais. Lietuvos valstybès atgimimui pagerbti ir šios istorijos periodui su garbinga praeitimi surišti nuspręsta pastatyti didelị bronzinị paminklą Didžiojo Lietuvos kunigaikščio Vytauto su pakeltu kardu ant arklio, atvaizduojant kautynėse su priešu, kaip pavyzdžiui, Mateikos - kautynès ties Žalgiriu 1410 metais. Uždrausti vartoti didžiụjų Lietuvos kunigaikščių paveikslus reklamos ir biznio tikslams, kadangi tai ̨̇žeidžia atskirų piliečių ir ypač karių jausmus, o brangius senovès vardus tik nudèveja, profanuodami

\footnotetext{
25 Karo istorijos reikalu, Lietuva, 1922 m. vasario 16 d., Nr. 39.

26 Ten pat.
} 
dar juos kasdieniniais ir nustojusiais idèjinès reikšmès ${ }^{\text {“27. }}$.

Išskirtinị dėmesị suvažiavimo dalyviai skyrẻ Karo muziejui, prašydami siekti „pastatyti fundamentalius ir gražius Karo muziejaus rūmus, kurie galètų sutalpinti greit augantị Muziejų ir savo išvaizda visai atitiktų tiems tikslams, kuriuos užsibrèžè sau mūsų tautos ir kariuomenès paminklas - Karo muziejus ${ }^{\text {“ } 28}$.

Krašto apsaugos ministras kreipèsi ir i visus Lietuvos kariuomenès karius, ragindamas rinkti senosios istorijos liekanas ten, kur jie gyvena ir tarnauja. Išskirtinis dèmesys turètų būti kreipiamas ị knygnešių veiklą, Lietuvos vargus Pirmojo pasaulinio karo metais, atskleidžiant Lietuvos naikinimo mastus, reikètų aktyviai rinkti okupantų valdininkų nuotraukas, uniformas, ginklus, nes ši medžiaga labai greitai nyksta.

Visa surinkta medžiaga turèjo būti pristatyta ì muziejų iki $1922 \mathrm{~m}$. vasario $6 \mathrm{~d}$., nes vasario $16 \mathrm{~d}$. buvo numatyta Laisvės varpo pašventinimo ceremonija.

Muziejaus kūrimo ir kasdienę veiklą aktyviai rèmè ir Amerikos lietuviai. Jie aukojo ne tik pinigus, bet ir eksponatus. JAV gyvenantis kunigas dr. Vincas Bartuška padovanojo gipsinị Vytauto biustą, o per kpt. Ladą (Vladą) Natkevičių Amerikos lietuvių organizacijos paaukojo 28300 auksinų. Muziejaus rinkinius papilde ir nesenų ìvykių, Klaipėdos sukilimo, „daiktai-liudininkai“: 1923 m. gegužès 19 d. Klaipèdos krašto ir Šilutès komendantas padovanojo muziejui tris šautuvus, kuriuos šauliai atèmè iš vokiečių, o birželio $24 \mathrm{~d}$. Antanas Kniukšta - iš priešo atimtus pistoletą „Dreyse“, policininko kardą, tris kulkosvaidžius, iš kurių vienas buvo vokiečių $1915 \mathrm{~m}$. lengvasis 7,92 mm kalibro MG 08/15 („Maxim“), Nr. 3707, o antras - prancūzų, $1915 \mathrm{~m} .8 \mathrm{~mm}$ kalibro „Šoša“ („Chauchat“), Nr. 95574, 10-ojo pèstininkų Klaipėdos savanorių pulko, kurie ir dabar saugomi muziejuje ${ }^{29}$. Eksponatus muziejui rinko ir dr. Jonas Basanavičius, ieškojo jų Latvijos bažnyčiose ir muziejuose.

Karo muziejus buvo kuriamas kartu su sodeliu ir turèjo sudaryti visumą, papildyti vienas kitą, atspindèti Lietuvos valstybingumo idejos igyvendinimą ir kovas dèl jos. Pirmuoju tų kovų ịamžinimo simboliu tapo paminklas „Žuvusiems už Lietuvos laisvę“. Skulptorius Juozas Zikaras ir

\footnotetext{
27 Ten pat.

28 Ten pat.

29 Gauti eksponatai iš 10 p. Klaipedos savanorių pulko, $L C V A$, f. 1764, ap. 1, b. 87, 1. 1.
} 
architektas Vladimiras Dubeneckis, parengęs paminklo projektą, iš kovų už laisvę vietų atvežtų akmenų sukūrẻ piramidę. Paminklo atidengimo iškilmès ịvyko $1921 \mathrm{~m}$. spalio $16 \mathrm{~d}$. 11 val. $30 \mathrm{~min}$. Jose dalyvavo Lietuvos Respublikos prezidento pareigas einantis Steigiamojo Seimo pirmininkas Aleksandras Stulginskis, ministras pirmininkas Kazys Grinius, krašto apsaugos ministras prof. Jonas Šimkus, užsienio šalių - Prancūzijos, Latvijos - ministrai, Rusijos atstovybių nariai, Danijos konsulas ir Tautų Sąjungos kontrolès komisijos nariai, kariuomenès vadas gen. Juozas Kraucevičius, Vyriausiojo gynimo komiteto pirmininkas Mykolas Sleževičius, kariuomenès ir visuomenès atstovai.

Paminklo atidengimo proga pirmą kartą buvo sugrotas kompozitoriaus Juozo Tallat-Kelpšos sukurtas karinis Gedulingas maršas, choras giedojo „Libera“. Jau tą pačią dieną buvo pradètos kurti tam tikros tradicijos, skirtos karių atminimui pagerbti. Paminklo „Žuvusiems už Lietuvos laisvę" svarbą valstybei prezidentas A. Stulginskis apibūdino taip: „Patsai paminklas žymètinas savo originalumu: nežiba puikumu ar išdidumu, bet paprastas ir liūdnas, kaip mūsų tyki vargingoji senovè. “" ${ }^{30}$ Prezidentas, dèkodamas visiems, prisidejusiems prie paminklo atsiradimo, pasakè, kad skulptorius J. Zikaras sugebejjo jam ikvejpti dvasią ir pastatyti prie „mūsų tautinès brangenybès - Karo muziejaus“, o gen. ltn. V. Nagevičiaus dèka „čia rūpestingų rankų surinkta daug atminimo iš tų netolimos praeities žygių, pakeltų dèl tèvynès laisvès - nepriklausomybės. Daug pasitarnavo tautai ir Valstybei tie garbingi Lietuvos piliečiai, kurių rūpesčiu neduoda žūti taip brangioms mūsų išsiliuosavimo ir Valstybės atstatymo relikvijoms“"31.

Paminklas „Žuvusiems už Lietuvos laisvę“ buvo gerbiamas ne tik per šventes, bet ir kasdien. Krašto apsaugos ministro įsakymu buvo nustatyta tvarka, kaip reikia pagerbti žuvusiųjų atminimą, kokios vèliavos ir virš kokių pastatų turi būti keliamos: „Valstybinė ir tautinè vèliavos Karo muziejaus bokšte, o Vyties Kryžiaus vèliava prie „Žuvusiems už Lietuvos laisvę" paminklo nuo gruodžio $1 \mathrm{~d}$. ligi sausio $31 \mathrm{~d}$. iškeliamos 9 val. ryto, o nuleidžiamos saulei leidžiantis. Kitais metų laikais -8 val. ryto iškeliamos, saulei leidžiantis nuleidžiamos.“

30 Isakymas kariuomenei Nr. 276, Kaunas, 1921 m. lapkričio 28 d., $\$ 1$.

31 Ten pat. 


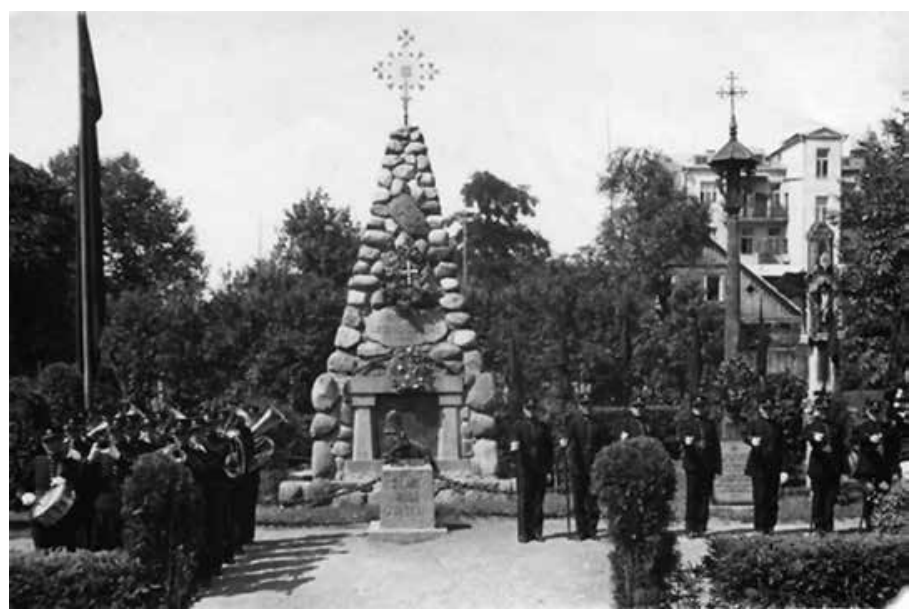

Karo

invalidai ir

orkestras

prie

paminklo

„Žuvusiems

už Lietuvos

laisvę".

Fa-14809

Šiam ritualui atlikti buvo sugalvota speciali vèliavų pakèlimo ir nuleidimo ceremonija. Ji pradèta rengti 1923 m. birželio mèn. Dr. Jonas Basanavičius, rašydamas apie Karo muziejų, išskirtinị dèmesị skyrè jo sukurtoms tradicijoms aprašyti:

„Karo muziejus išorinèse savo apeigose prie pakèlimo ir nuleidimo vèliavos. Laikui bėgant išdirbo gilias, harmoningas ypatingo kulto formas, būtent riteriško valstybinès vèliavos pagerbimo ir žuvusiųjų dẻl Lietuvos laisvès paminejjimo. Apeigų turinys savaime labai paprastas ir aiškus kiekvienam žiūrètojui ir veikia ji iš sykio savo rimtumu, kad ir kokio žiūrètojo būtų ūpo. Pagerbimas valstybinès vèliavos ir paminèjimas žuvusiụjų dèl laisvès čia iggyja ypatingai rimtos reikšmès, nes yra atliekama invalidų, kitaip tariant, bejègių, kurie savo kraują ir savo laimę atidavė Lietuvos labui jos kautynių lauke. Karo invalidai sudaro prie muziejaus garbès sargybą 10 žmonių ir išeina ị ceremoniją su savo mažu orkestru rikiuoteje, gražia uniforma su plieninemis kaskèmis, padabintomis auksiniais Vyties kryžiais ir pikèmis, papuoštomis narsiųjų plevėsuojančiomis vèliavutèmis. Prie paminklo invalidams susirenkant, signalistui sugriežus, mažu žingsneliu, taisyklingoje rikiuotejje, išlaikydama taktą, su orkestru ir maža saujele garbingos gvardijos, išẻjusi iš didžiųjų muziejaus durų ir palengva lazdelèmis pasiremdama, žengia prie paminklo ir sustoja ties jo šonu. Viršila sukomanduoja, saliutuodamas kardu, o rikiuotèje ịsakymą atliekant tuo pačiu laiku griežia orkestras. Pakeliant ar nuleidžiant vèliavą koman- 


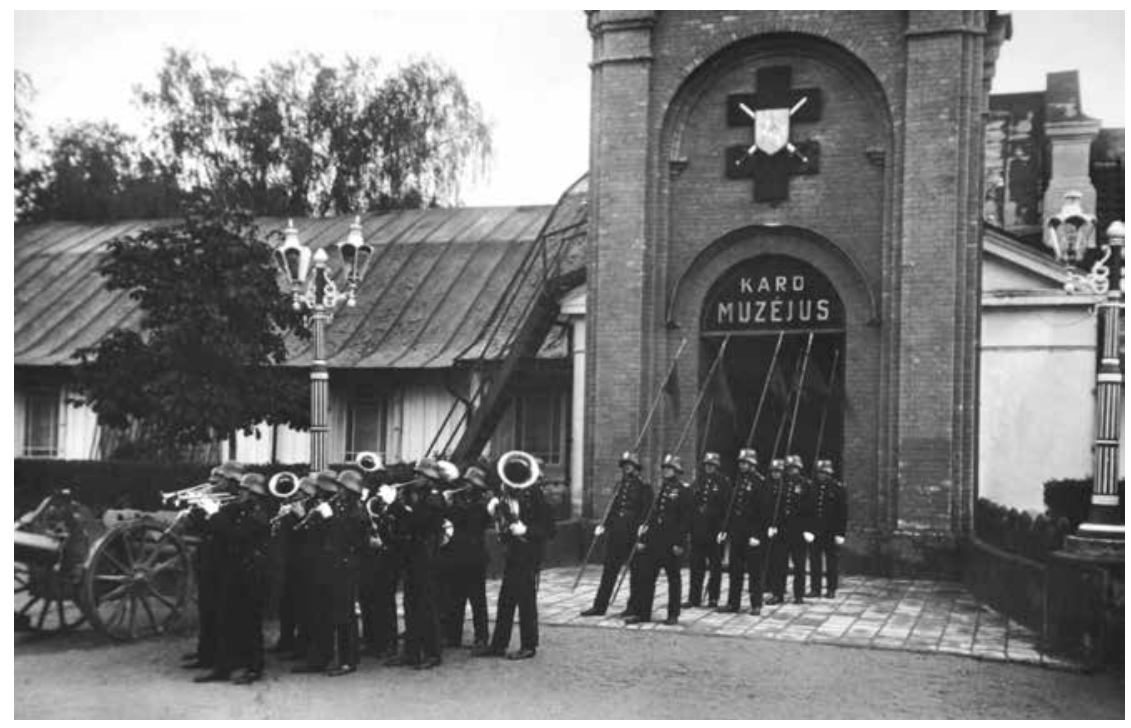

Karo invalidai žygiuoja iš Karo muziejaus atlikti žuvusių už Lietuvos laisvę karių pagerbimo, vèliavų pakèlimo ir nuleidimo ceremonialo. $1928 \mathrm{~m}$. N-57

duojama: „Valstybės vèliavai ginklu gerbk“, prieš maldą girdèt: „Už žuvusius maldai kepures nusiimt“. Kaskès su auksiniais kryžiais, suderintais judesiais nusiimamos nuo galvos ir žiūrètojas stebi, kad po jų pas vienus invalidus būta paslèptų baisių žaizdų randų. Iškilminga maldos melodija, sužibejjus ugnies kryžiui ant paminklo, skrenda erdvėn sujaudindama pakeliui net ir surambejusias širdis ir sielas, nors vienam momentui sužadindama prakilnius jausmus. Liepsnojantis aukuras siunčia danguosna gauruotus dūmų debesius, tarytum, senovès aukurų pavyzdžiu keldamos žmonių mintis ir maldas prie aukščiausiojo. Iškilmès užbaigiamos himnu. Susirinkusi minia, tarytum užsimiršusi, apsvaigusi, nesijudindama iš vietos, sekdama akimis, tyliai lydi grižžtančius į muziejų invalidus. Jų maršas, tarytum pilnai pilnas verksmo balsų, bet vis tik negedulingas; jaučiama gaidose pasiryžimo ir noro gyventi ir dirbti mylimai Lietuvai likusiomis jègomis. Bet štai akordai nurimo ir didelès masyvès muziejaus durys su trenksmu užsidaro, tarytum paslaptingai atskirdamos tuos jau „muziejinius žmones" nuo saulès šviesos ir gyvenimo džiaugsmo. “32

32 Basanavičius J. Iš Karo muziejaus istorijos, Mūsǔ žinynas, 1925, Nr. 22, p.123. 
Tą minios patiriamą jausmą puikiai aprašè kariuomenès kūrèjas savanoris Stasys Butkus: „Daugel kaimiečių vakare vaikštinėjo Karo muziejaus sodely ir dairèsi ị paminklus ir muziejų. Prasidarė muziejaus durys ir iš ten iš lèto išslinko išsirikiavę karo invalidai, einą prie paminklo žuvusiems pagerbti savo žuvusius draugus ir nuleisti muziejaus vèliavas. Jų tarpe su lazda pasiramsčiuodamas ejo ir Petras Sauginaitis. Nors veidą vagojo vargų, kovų ir kančių dienų išbraižyti vingiai, tačiau jis šiandien nebeatrode toks baisus, kaip anomis dienomis, kada nedrąsiai grižo namo. Dabar ị tuos veidus visi žiūrejo su pagarba ir tautiniu pasididžiavimu. - Štai, va, ir mano Petras žengia! - išdidžiai, pasididžiuodamas senis Sauginaitis, Petro tèvas, parode savo kaimynams <...> Ir akimis su pagarba nulydejo savo sūnų iki pat paminklo, sekè per visas vèliavų nuleidimo apeigas ir kol vèl grịžo ir užsidarė muziejaus durys, nusišluostė nuo savo skruostų ašaras ir pusiau tylomis lyg tai pats sau, lyg savo kaimynams pridūrè: - Ir vis dèlto jaunesnieji geriau už mus žino, ką jie darą... Ar mes tikejjomès, kaimynèl, šito. Nè sapne nesapnavom. “"33

1922 m. ỉ Lietuvą atkeliavo Amerikos lietuvių padovanotas Laisvès varpas, sveriantis $600 \mathrm{~kg}, 1,2 \mathrm{~m}$ aukščio ir $1 \mathrm{~m}$ pločio. Jis buvo pakabintas muziejaus bokšte. Vasario 16 d., minint 4-ąsias Nepriklausomybès metines, J. Tumas-Vaižgantas varpą pašventinto ir perskaitè eiliuotą jam skirtą savo kūrybos odę. Pirmasis Laisvès varpu paskambino prezidentas Aleksandras Stulginskis, po jo - Petras Vileišis, „Vilniaus žinių“ redaktorius, vyriausias amžiumi Europoje lietuvių visuomenès veikèjas. Prasidejus šventiniam kariuomenès paradui, varpu skambino karo invalidas Antanas Sereika ir jaunasis skautas Virkša. Ant Laisvès varpo buvo užrašas: „O skambink, per amžius vaikams Lietuvos, tas laisvès nevertas, kas negina jos!“ Tame pačiame bokšte buvo sumontuotas ir pradejo veikti Berlyno firmos „C. F. Rochliz“ laikrodis, nupirktas už aukas, kainavęs 100022 auksinus. Laikrodis mušè valandas ị 3334 kg varpą iš buvusios cerkvès bokšto. Laikrodžio laikas buvo nustatomas pagal Paryžiaus Eifelio bokšto elektros bangomis skleidžiamą signalą, kurio tikslumą tikrino radijo stotis. Prieš montuojant bokšte laikrodị, kilo mintis ten sumontuoti ir varpų muzikos ịrenginį. Sukviestų muzikų pasitarime buvo nuspręsta, kad varpų muzikos reikia. $1922 \mathrm{~m}$. spalio pabaigoje ì bokštą buvo ịkelti devyni karinès igulos cerkvèse Lietuvoje buvę varpai: Papilès

33 Butkus S. Ir mano Petras žygiuoja..., Lietuvos karo invalidas, 1935, Nr. 1, p. 24. 
R. K. bažnyčios (68 kg), Kèdainių stačiatikių (160 kg), Aukštosios Fredos $(265 \mathrm{~kg})$, Gardino (100 kg), sentikių cerkvés Suvalkų rédybos (gubernijos) (205 kg), Sofijos Gardino rédybos (88), Gardino Vladimiro cerkvès $(420 \mathrm{~kg})$, Perstuno cerkvès Suvalkų rèdybos $(68 \mathrm{~kg})$ ir Dubno cerkvès Suvalkų rèdybos $(68 \mathrm{~kg})^{34}$. Muziką bokšto varpams parengè kompozitorius Antanas Kačanauskas. Muzikos vole, kurị muziejus ịsigijo iš vokiečiu firmos „Rochliz“ Berlyne, buvo ịrašytos Tautos himno ir giesmès „Marija gražiausia panelë" natos. Ši giesmè skambèdavo tris kartus per dieną - 8, 12 , ir 14 val. Varpai buvo įrengti už pinigus, kuriuos paaukojo prezidentas Aleksandras Stulginskis, Lietuvos ùkio bankas, Lietuvos pramonès ir prekybos bendrové, Lietuvos žemès ükio spirito varyklos bendrové, Akcinè bendrové „Nemunas“ ir kt. Iš viso buvo paaukota 526712 auksinų. Varpų muzikos ịrenginị ịtaisẻ iš Liubeko atvykęs meistras Olsanas. Apie senojo muziejaus varpus dr. Jonas Basanavičius rašè: „Kaip matoma, likimo norèta, kad tie varpai, kurie kitados buvo rusų valdžios gabenami Lietuvon skelbti pravoslaviją ir „obrusenija Severo-Zapodnovo iskonno ruskovo kraja", nūnai, susirinkę iš Lietuvoje buvusių cerkvių Karo muziejaus bokšte, vakarais majestotiškai gieda Šidlavos giesmę, o didelių iškilmių dienomis, orkestro lydimi Lietuvos nepriklausomybei pagerbti, sutartinai griežia jos himną, pritariant Laisvès varpui." Tais pačiais metais muziejaus bokštas buvo papuoštas didžiųjų Lietuvos miestų - Klaipèdos, Kauno ir Vilniaus - herbais.

Noredamas ịprasminti Laisvès varpo vaidmenį, muziejaus organizatorius gen. ltn. V. Nagevičius pasiūlè keturias progas, kuriomis reikètụ juo skambinti: „1. Politinès reikšmės: nepriklausomybès paskelbimas, Vilniaus konferencijos, Steigiamojo seimo ir panašūs atsitikimai; 2. Karo istorijos svarbiausi momentai: mūšis ties Žalgiriu, Širvintais, Kalkūnais ir t. t.; 3. Kultūros kovos: spaudos atgavimas, pirmosios mokyklos, universiteto įsteigimas; 4 . Socialès bei ekonominès svarbos: paleidimas iš

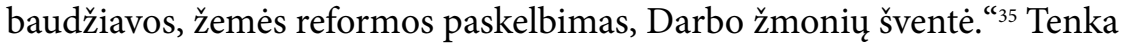
tik apgailestauti, kad šio pasiūlymo ne visada buvo laikomasi. Dažniausiai Laisvès varpas skambèdavo valstybinių ir kariuomenès švenčių progomis.

34 Išimtų iš senojo Karo muziejaus ir parduotų bažnyčioms varpų sąrašas, LCVA, f. 1764, ap. 1, b. 196, 1. 65 .

35 Basanavičius J. Iš Karo muziejaus istorijos, Mūsų žinynas, 1921 m., Nr. 21, p. 494. 
Sodeliui įrengti ir prižiūrèti pinigų nebuvo skirta, todèl viskas buvo daroma už aukas. Išskirtinė auka buvo Raudonojo Kryžiaus Vakarų Rusijai ir Baltijos valstybėms komisaro plk. Edvardo W. Ryano. Jis muziejaus sodeliui paaukojo 100 rožių krūmų - jie buvo pasodinti prie paminklo „Žuvusiems už Lietuvos laisvę“. Apie šią dovaną pats pulkininkas muziejaus Aukų knygoje parašè: „Šiandien aš turiu garbès pasodinti šimtą rožių krūmų šalia paminklo, pastatyto žuvusiems kovoje už Lietuvos laisvę kareiviams. Šios rožès sodinamos lietuvių tautos narsumui pažymèti... Aš tikiuosi tačiau, kad su pirmutiniais šių krūmų žiedais jau bus išsipildę Lietuvos teritoriniai pageidavimai, kurie, visų protingų ir teisingų žmonių manymu, yra teisingi ir teisèti.“ Sodelyje augančių rožių buvo galima nusipirkti iš budinčio karo invalido keturis kartus per dieną: 8, 12, 16 ir 20 val. Gautos pajamos buvo naudojamos sodelio priežiūrai apmokèti. Tačiau rožès buvo ne tik parduodamos, bet ir dovanojamos. Žmonès iki šiol prisimena, kad gen. ltn. V. Nagevičius rožes dovanodavo moterims ir merginoms, Karo muziejaus lankytojoms, „tautiškais drabužiais apsitaisiusioms“. Šitaip jos buvo skatinamos dèvèti tautinius rūbus ir taip buvo kuriama dar viena tradicija.

1923 m. lapkričio 23 d. Lietuvos kariuomenès 5-erių metų sukaktuvių proga buvo atidengtas dailininko Juozo Zikaro sukurtas dr. Jono Basanavičiaus biustas. Jis buvo nulietas iš šovinių, paleistų i priešus, tūtelių, o postamentas pagamintas iš akmenų, žymejjusių sieną tarp Didžiosios ir Mažosios Lietuvos. Visuomenè šiam paminklui paaukojo 5 619,32 lito. Biusto atidengimo iškilmes paskelbẻ Laisvès varpo dūžiai, paminklą, dalyvaujant pačiam dr. J. Basanavičiui, atidenge prezidentas Aleksandras Stulginskis, o pašventino Jonas Mačiulis-Maironis. Po iškilmių prie paminklo „Žuvusiems už Lietuvos laisvę“ šv. Mišias aukojo Lietuvos kariuomenès vyriausiasis kapelionas kunigas Antanas Palubinskas. Tą dieną pirmą kartą buvo uždegtas aukuras, pastatytas iš likusių nuo dr. Jono Basanavičiaus postamento akmenų. Ant aukuro priekyje buvo užrašas: „Redde, quod debes“/ Petronius / („Grąžink, ką privalai“). Šiame aukure uždegta ugnis buvo skiriama žuvusių karių atminimui pagerbti ir tai tapo dar viena Karo muziejaus organizatoriaus sugalvota ir igyvendinta tradicija. Muziejaus konservatorius gen. ltn. V. Nagevičius prie paminklo „Žuvusiems už Lietuvos laisvę“ norejo įrengti tarsi mažas kaimo kapinaites - ten turejjo stovèti lietuviški kryžiai. Ši idejja buvo igyvendinama palaipsniui. 1923 m. du kryžius muziejui padovanojo „Lietuvos geležin- 
keliai“, vieną kryžių kunigas Vincentas Senkus atveže iš Plungès kapinių, o kryžius iš Kretingos buvo gautas mainais ị Kęstučio paveikslą. 1925 m. iš Taujẻnų buvo atvežtas aukštaitiškas kryžius su „smūtkeliais“ iš visų pusių. Prie paminklo buvo pastatyti dar keli kryžiai: vienas - $1863 \mathrm{~m}$. sukilèliams, du - $1905 \mathrm{~m}$. Didžiajam Seimui paminèti ir dar „du kryžiai iš naujų Nepriklausomybès laikų“.

Muziejaus sodelis buvo ne tik patriotizmo ugdymo, bet ir kultūringo laisvalaikio leidimo vieta. Čia buvo rengiami valandos trukmès koncertai. Simfoniniams koncertams diriguodavo Juozas Tallat-Kelpša, kameriniams - smuikininkas M. Hofmekleris. Vèliau buvo rengiami ir dūdų orkestro koncertai. Juose būdavo atliekami lietuvių liaudies, Juozo Gruodžio, Stasio Šimkaus ir užsienio autorių muzikos kūriniai. Tačiau šie koncertai buvo išskirtiniai - kūriniai būdavo atliekami tik vieną kartą, nebuvo galima šaukti „bis“ ir ploti. Publika turèjo susikaupusi išklausyti visą programą. Adomas Jakštas šiuos koncertus ịvertino taip: „Nesitenkindamas patriotizmo žadinimu, mūsų Karo muziejus yra pastatęs sau dar kitą tikslą - kultūrinti mūsų publiką... Viskas čia eina rimtai, tvarkingai, kultūringai. Generolui Nagevičiui, tų koncertų iniciatoriui ir organizatoriui, priderama visuomenès padèka..." ${ }^{\text {"36 }}$

Apie koncertus Karo muziejaus sodelyje ir muziejų pats gen. ltn. V. Nagevičius saké: „Mums, lietuviams, reikia siekti to, kas aukšta, prakilnu. Svarbu ne namas, $\mathfrak{i}$ kurị mes renkamès, bet nuotaika, kuri mus apima. Mūsų sieloje slypi jausmas siekti prakilnumo. Čia matome daug daiktų, kurie gal nedaug teturi meno, bet daug mums pasako, nes vaizduoja mūsų tautos praeitį ir kovą už laisvę. Kitas dalykas, kuris mus jungia, - tai muzika."

Tačiau prie muziejaus vyko ne tik koncertai, bet ir karių pagerbimo ceremonijos. $1924 \mathrm{~m}$. gegužès $10 \mathrm{~d}$. buvo surengtos didelès iškilmés, skirtos Lietuvos karininkų apdovanojimui Čekoslovakijos karo kryžiumi „Križ Vąlečny". Ta proga muziejaus bokšte buvo iškelta Čekoslovakijos vèliava, iškilmèse dalyvavo šios valstybès atstovas Lietuvoje prof. Janas Galia. Jis padèjo didelę puokštę gèlių su Čekoslovakijos vèliavos spalvų kaspinais, o išvykdamas iš Lietuvos $1928 \mathrm{~m}$. padovanojo Karo muziejui savo sukurtą maršą chorui ir orkestrui „Te Deum laudamus“ (Dieve, šloviname tave), dar 1923 m. jis muziejui buvo padovanojęs Čekoslovakijos vèliavą.

36 Basanavičius J. Iš Karo muziejaus istorijos (atviras laiškas valdžios ir Seimo atstovams), Lietuva, Nr. 236, 1924 m. spalio 18 d. 
1927 m. vasario 16 d. mirè dr. Jonas Basanavičius, todèl Karo muziejaus sodelis paskendo gedule. Penkias dienas jo biustas buvo apjuostas gedulo juostomis, o vasario $21 \mathrm{~d}$. Seime ívyko posėdis patriarcho atminimui pagerbti. Prie degančiais aukurais papuošto dr. J. Basanavičiaus paminklo vainikus padejo prezidentas Antanas Smetona, Seimo pirmininkas, kariuomenès, Lietuvos kariuomenès kūrèjų savanorių, Šaulių ir Tautininkų sajungų atstovai, Lietuvos universiteto ir studentų korporacijų nariai, medicinos draugijos ir kitų organizacijų atstovai, moksleiviai. Šia proga prie muziejaus durų buvo surengta inscenizacija, vaizduojanti Gedimino kalną ir pili, kur „patsai Gediminas, tarsi palikęs savąji amžinasties poilsį, čia stojęs irgi liūdi perjuostas gedulo šydais, o Lietuvos kariai, vėliava nešini, prie patrankų stovi, lyg pasiryžę pavartoti ir tą pabūklą, jei to pareikalaus sostinès vadavimas..." ${ }^{\text {"37 }}$ Mišias laikè kariuomenès kapelionas Adolfas Sabaliauskas.

1921 ir 1928 m. gegužès 15-ąją buvo švenčiama Steigiamojo Seimo sušaukimo diena. Sodelyje susirinko valstybės ir Seimo nariai, užsienio pasiuntinybių ir konsulatų atstovai. Tų šalių vẻliavomis buvo papuoštas muziejus, kaip tai buvo padaryta ir 1925 m. gegužès 15 d., švenčiant Baltijos ir Skandinavijos valstybių santarvès dieną. $1927 \mathrm{~m}$. gegužès 15 d., minint Steigiamojo Seimo sušaukimo septintąsias metines, buvo atidengti Simono Daukanto ir dr. Vinco Kudirkos biustai. Biustus pašventino kanauninkas Juozas Tumas-Vaižgantas, apie Simoną Daukantą pakalbejjo prof. Mykolas Biržiška, o apie Vincą Kudirką - J. Tumas-Vaižgantas. Biustai buvo nulieti Berlyne, o postamento akmenys atvežti „nuo buvusios Klaipèdos krašto sienos Palangos rajone“. Abu paminklai buvo aptverti aštuoniomis vokiečių minosvaidžių minomis, gautomis iš Artilerijos sandèlio, sujungtomis 3,6 m ilgio grandine, pagaminta Centrinèse kariuomenès dirbtuvėse.

Kiekvienais metais muziejaus konservatorius gen. ltn. V. Nagevičius sugalvodavo kokį nors naują renginị, ir šis netrukus tapdavo tradicinis. 1927 m. spalio 9 d. buvo iškilmingai paminèta Suvalkų sutarties sulaužymo diena. Laikraštis „Lietuva“ apie ši renginị rašè: „Jau nuo pietų Karo muziejaus sodelis pilnas žmonių. Visi vaikšto siaurutėmis alejjomis ir sustoja ties Vilniaus paveikslu pasigrožèti tuo puikiu mūsų tikrosios sotinès miestu. Ne vienas nusistebi, kad plevėsuojančios Karo muziejaus vèlia-

37 Laidotuvių gedulo apeigos, Lietuva, Nr. 42, 1927 m. vasario 22 d. 
vos neperrištos gedulo juosta, tuo tarpu visas Kaunas apsitraukęs gedulo šydu. ${ }^{\text {"38 }} \mathrm{I}$ ṣ̌ klausimą atsakè gen. ltn. V. Nagevičius, pradèdamas renginị. Jis perskaite Lietuvos didžiųjų kunigaikščių pasižadèjimą „dèl Lietuvos garbès ir žemių čielybès", pasirašytą $1588 \mathrm{~m}$. Todèl buvo paklausta, kodèl turime liūdinti ir silpninti savo dvasią ir mažinti pasiryžimą? „Ne verkdami atgausim Vilnių. Kova, kova ir kerštas mūsų grobikams už išplešstą sostinę. 39" Po generolo kalbos Vilniaus vaduoti sąungos pirmininkas prof. Mykolas Biržiška su sąjungos nariais padèjo gèlių prie paminklo „Žuvusiems už Lietuvos laisvę“. Nuo 15 iki 17 val. visuomené lankè muziejų, o atvykus ministrui pirmininkui prof. Augustinui Voldemarui, lydimam kariuomenès vado ir štabo viršininko, prièmé kariuomené paradą ir, visiems susirinkusiesiems sugiedojus Lietuvos himną, padejjo vainiką prie dr. J. Basanavičiaus paminklo. Spalio 9 d. minejjimas tapo tradicija. Jis buvo minimas kasmet. Sodelyje buvo švenčiamos ne tik valstybinès šventès, rengiami koncertai, bet ir minimos Vèlinès. Renginiai prasidèdavo miesto kapinèse ir baigdavosi sodelyje, kuris būdavo atitinkamai iliuminuotas ir parengtas.

Kaip minèta, Karo muziejaus sodelyje tradiciškai buvo švenčiamos ne tik valstybinès šventès. Iškilmingas mirusiųjų pagerbimas taip pat tapo tradicija. $1927 \mathrm{~m}$. lapkričio $2 \mathrm{~d}$. sodelis atrodè lyg pasruvęs krauju, paminklas „Žuvusiems už Lietuvos laisvę" buvo apjuostas lemputėmis, apačioje jos švietė raudonai. Prieš paminklą degè trys aukurai: viduryje akmeninis, kraštuose - taurès formos, visi beveik lygūs su paminklu. Kiti paminklai taip pat buvo papuošti vainikais ir žibintais. Sodelyje tvyrojo mistinè nuotaika, tarsi žuvusiųjų karių vèlès būtų tarp gyvųjų. Tą dieną visos vèliavos buvo nuleidžiamos per trečdali stiebo. Prie muziejaus buvo pagerbiami ir mirę iškilūs Lietuvos žmonés. $1930 \mathrm{~m}$. mirẻ prof. Jonas Jablonskis, todèl jo laidotuvių dieną prie Laisvès paminklo buvo pakabintas patriarcho portretas. Jị iš abiejų pusių puošė gedulingos vèliavos ir žvakidès, o paminklo papėdèje buvo sudèti vainikai. Garbės sargyboje stovejo karo invalidai, gedulingus maršus grojo muziejaus orkestras. Panašios iškilmès buvo surengtos ir pagerbiant mirusị Joną Mačiulị-Maironị.

Muziejus ne tik kūrè naujas tradicijas, gerbè žuvusius karius ir mirusius Lietuvos visuomenès veikèjus, bet ir vykdè savo tiesiogines funkcijas,

${ }^{38}$ Kor. Spalių 9 d. minejjimas Karo muziejuje, Lietuva, Nr. 228, 1927 m. spalio 10 d.

39 Ten pat. 


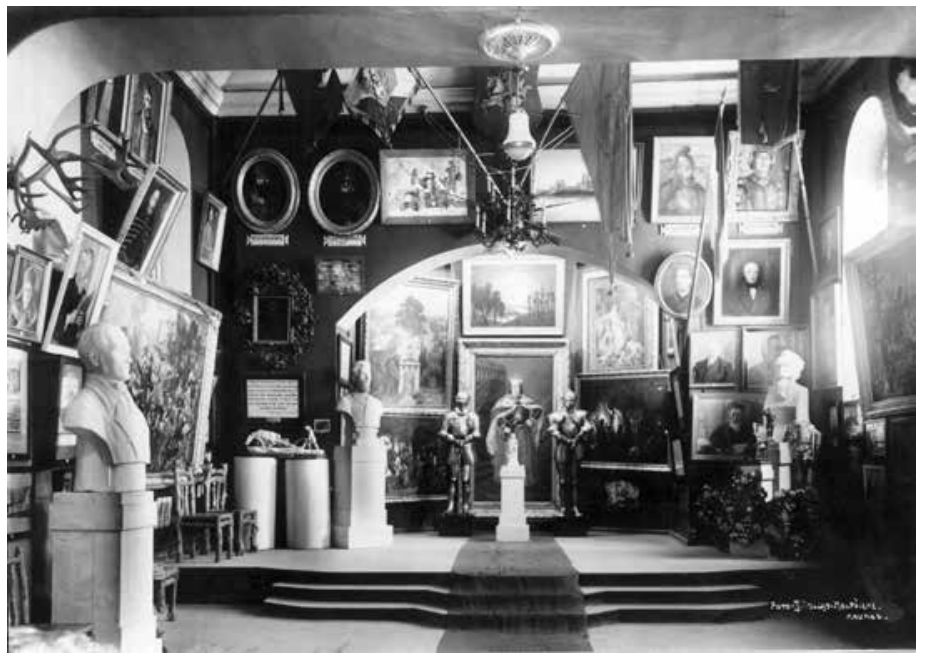

Senojo

Karo

muziejaus

Izžanginio

skyriaus

ekspozicija.

$1929 \mathrm{~m}$.

N-80

kaupè eksponatus. 1928 m. sausio 1 d. jame buvo saugoma 1300 eksponatų. Per septynerius muziejaus veiklos metus buvo įsigytos 5 vèliavos: 1-ojo atsargos bataliono Vitebske, Lietuvių atsargos bataliono Smolenske, 1-ojo atskirojo Vytauto Didžiojo lietuvių bataliono Sibire, Vakarų fronto lietuvių suvažiavimo ir Klaipèdos sukilèlių. Buvo nutapyti arba nupirkti Lietuvos didžiųjų kunigaikščių, Lietuvos atgimimo ir Nepriklausomybės veikèjų, savanorių kario Povilo Lukšio ir karininko Antano Juozapavičiaus, taip pat kitų karių portretai ir batalinių scenų paveikslai. Muziejus sukaupé nemažai gipsinių biustų ir bareljefų: turejjo dr. J. Basanavičiaus, Lietuvos didžiojo kunigaikščio Gedimino, vyskupo Antano Baranausko biustus, Simono Daukanto, Adomo Mickevičiaus ir Julijos Žemaitès bareljefus.

Muziejui buvo perkama ir įranga. Jau $1921 \mathrm{~m}$. iš Berlyno „Fridr Wichlerich“ firmos ịsigyti 9 manekenai, kautynèse ties Seinais iš lenkų vyr. ltn. A. Kemiežio atimta lenkų vèliava „Bože zbaw Polskę“, ịvairių vokiškų, rusiškų, japoniškų šautuvų, revolverių ir kardų. 1922 m. III dragūnų „Geležinio Vilko“ pulkas padovanojo vilko ir vilkès, sumedžiotų kunigaikščio Konstantino Radvilos giriose, kailius, 1923 m. I pėstininkų pulkas - kumelę Birutę, nupirktą už valdiškus pinigus 1919 m. vasario $14 \mathrm{~d}$. ir kovose sužeistą i nugarą, bet sugebejjusią nueiti 90 kilometrų iš Daugų i Marijampolę, kur buvo išgydyta. Kèdainių komendantas iš Totlebeno dvaro atvežè Radvilų patranką, buvo įsigyti du moteriški 
manekenai, kuriuos aprenge Sofija Čiurlionienè Didžiosios ir Mažosios Lietuvos tautiniais drabužiais, 1924 m. - Kajetono Sklèriaus paveikslas "Amerikos karo laivai Klaipejdoje“ ir kitų autorių darbai - Šv. Kazimiero ir prezidentų portretai.

1928-ieji buvo nepriklausomos Lietuvos dešimtmečio metai. Renginių, skirtų šiam jubiliejui paminèti, pagrindinis organizatorius Kaune buvo Karo muziejus. Pats svarbiausias renginys, skirtas Nepriklausomybės dešimtmečiui ir Laisvès skulptūros atidengimui, buvo gegužè 15-osios iškilmès. Šventè prasidèjo dar išvakarèse, gegužès $14 \mathrm{~d}$., pirmadienị. Karo muziejaus sodelyje ir Vienybès aikštèje 18 val. susirinko didžiulè minia žmonių, atstovaujančių ịvairioms organizacijoms. Laisvès statula buvo uždengta trispalve, o prie jos pastatyta tribūna papuošta gèlèmis. Prie tribūnos sustojo ministras pirmininkas Augustinas Voldemaras ir Ministrų Kabineto nariai, diplomatinis korpusas, Vokietijos karininkai ir visi rezidavę Lietuvoje karo atašè. Atvykstant prezidentui Antanui Smetonai, krašto apsaugos ministrui plk. Teodorui Daukantui, Vyriausiojo štabo viršininkui gen. št. plk. Povilui Plechavičiui buvo grojamas maršas ir aidejo garsus „valio“. Karo invalidų viršilai davus ịsakymą „Ginklu gerbk!“, Šaulių chorui giedant maldą „Kritusiems karžygiams“, buvo padėti vainikai prie paminklo „Žuvusiems už Lietuvos laisvę“. Tradicinị vokišką vainiką su balta juosta ir geležinio kryžiaus ženklu padejo ir Vokietijos karininkai gen. št. plk. Otas Karlas Šrioderis, gen. št. mjr. Rudolfas Detmeringas, gen. št. kpt. Karlas Almendingeris ir vyr. ltn. Heidendorfas. Rytojaus dieną ịvykęs Laisvès paminklo atidengimas buvo pagrindinis dešimtmečio akcentas. Prieš muziejų pastatytą paminklą sukūrè skulptorius Juozas Zikaras, architektas Vladimiras Dubeneckis, o statybos darbus atliko inžinierius Feliksas Vizbaras. Trijų metrų Laisvès skulptūrą, nulietą Berlyne už 5360 Lt, muziejui padovanojo Vyriausiasis Lietuvos gynimo komitetas, nupirkęs ją iš autoriaus. Jos postamentui buvo panaudoti septyni didžiuliai akmenys iš Didžiosios ir Mažosios Lietuvos pasienio ir trys akmenys iš Ežerẻnų ${ }^{40}$. Paminkle iš trijų pusių buvusiose lentose buvo nurodytos Nepriklausomybės kovų pergalių vietos: „Panevėžys Dauguva, Radviliškis 1919“, „Širvintai Giedraičiai 1920“, „Klaipèda 1923“, o fasade užrašas - „Karžygiai“. Atidengdamas paminklą, prezidentas Antanas Smetona pasakè kalbą, kurioje pabrěžè, kad „laisvè veltui neịgyjama. Rei-

40 1919-1929 m. taip buvo vadinami Zarasai. 
kia vargti, dirbti ir susiklausyti. Taip pasieksime visą laisvę" ${ }^{\text {411 }}$. Po to jis atidengè paminklą, patraukdamas trispalvị kaspiną. Tada sugaude Laisvès varpas, visi sugiedojo Tautos himną ir buvo nuimta vèliava.

Baigiamasis Nepriklausomybės10-mečio renginys buvo Kariuomenès dienos iškilmès, Karo muziejuje prasidejjusios 13 val. Vyčio Kryžiaus ordino tarybos iškilmingu posèdžiu. Muziejuje netilpo iš visos Lietuvos atvykę Lietuvos universiteto profesoriai, aušrininkai, užsienio karo atašè, žuvusių karių tèvai, seserys ir broliai, šauliai, karo invalidai, vietos ir užsienio spaudos atstovai. Posėdis prasidejo himnu ir žuvusiuju pagerbimu atsistojant. İžanginę kalbą pasakè muziejaus organizatorius, Vyčio Kryžiaus tarybos pirmininkas ir Vyčio Kryžiaus ordino kavalierius gen. ltn. V. Nagevičius. Jis pasveikino Lietuvos prezidentą, padèkojo arkivyskupui Juozapui Jonui Skvireckui už apsilankymą ir perskaite pranešimą apie Vyčio Kryžiaus atsiradimą ir istoriją. Prezidentas pasveikino susirinkusiuosius ir įteikè Vyčio Kryžiaus ordinus gen. Vincui Grigaliūnui-Glovackiui, gen. ltn. V. Nagevičiui, plk. ltn. Antanui Michelevičiui, mjr. Zigmui Rumšai, karo invalidui Jurgiui Barčiui, Marcelei Kubiliūtei ir Aldonai Čarneckaitei. Šiai iškilmingai dienai muziejuje buvo parengta speciali karinès spaudos paroda. Susirinkusieji, apžiūrèję parodą, dalyvavo vainikų padejjimo prie paminklo „Žuvusiems už Lietuvos laisvę“ ceremonijoje. Nuo tų metų Kariuomenès diena visada buvo labai glaudžiai susijusi su Karo muziejumi - čia ją švęsdavo tauta.

Tarpukario Lietuvoje pamažu susiklostè tradicija Naujuosius metus sutikti Karo muziejaus sodelyje. Jos iniciatorius ir vèl buvo gen. ltn. V. Nagevičius. Jis norejjo, kad kuo daugiau žmonių susirinktų prie muziejaus, su bokšto laikrodžio dūžiais palydètų senuosius ir sutiktų naujus metus. 1929 m. Naujųjų sutikimas prasidèjo dar likus 5 minutèms iki 12 val. Per garsiakalbius pasigirdo: „Alio, alio, radijo Kaunas! Transliacija iš Karo muziejaus." Tribūnoje pasirodè gen. ltn. V. Nagevičius ir pasakè trumpą kalbą, linkèdamas visai tautai ir kraštui kitais metais atgauti Vilnių. Po generolo žodžių laikrodis pradèjo skaičiuoti paskutines senųjų metų minutes, o po dvylikto dūžio gen. ltn. V. Nagevičius sušuko: „Valio! Sveikinu su Naujaisiais metais!“ Tuo pat metu sušvito šventinè iliuminacija: „Be

41 P. Respublikos Prezidento žodis (pasakytas atidengiant gegužès 14 d. Laisvès paminklą Karo muziejaus sode), Lietuvos aidas, Nr. 86, 1928 m. gegužès. 18 d. 
Vilniaus nenurimsim!“ Tada pradèjo skambèti Laisvės varpas, orkestras užgrojo Lietuvos himną ir, aidint paskutiniams jo akordams, dangus nušvito fejerverkais. Ši tradicija tęsèsi iki $1940 \mathrm{~m}$. sovietų okupacijos.

1930-ieji buvo paskelbti Vytauto Didžiojo metais, nes buvo minimos jo 500-osios mirties metinès. Šiai datai buvo skirtas ne vienas renginys, tačiau vienas ịsimintiniausių buvo iškilmingas Žalgirio mūšio 520-ụju metinių minèjimas Karo muziejuje. Šio renginio tikslas buvo pabrěžti Vytauto indèli i Žalgirio mūšio pergalę.

Liepos $12 \mathrm{~d}$. 16 val. ̨̣ muziejaus sodelį atėjo švietimo ministras Konstantinas Šakenis, vidaus reikalų ministras Petras Aravičius, karšto apsaugos ministras gen. Juozas Kubiliūnas, susirinko karininkai, valdininkai, tūkstantinè kauniečių minia. Minèjimą pradejjo gen. ltn. V. Nagevičius, po to suteike žodị istorikui prof. Ignui Jonynui. Jis ỉvertino ano meto Europos politinę padètį ir Žalgirio mūšio reikšmę. Kitą paskaitą „Žalgirio mūšis karo meno šviesoje" skaite plk. Stasys Zaskevičius. Po paskaitų vyko jungtinio 130 muzikantų orkestro, sudaryto iš Karo muziejaus, 2-ojo pèstininkų ir Husarų pulkų orkestrų, koncertas, po jo - vèliavos nuleidimo ceremonija, padalyta ị dvi dalis: viena - prie Laisvès paminklo, kita - prie paminklo „Žuvusiems už Lietuvos laisvę“. Sodelis buvo papuoštas tai dienai skirtais atributais. Prie Laisves paminklo buvo pastatytas Vytauto biustas ir didelis Žalgirio mūšį vaizduojantis paveikslas. Šios šventės aprašymas leidžia teigti, jog tuo metu buvo ieškoma nauju renginių formų, kad žmonèms būtų ịdomu - kad kaskart jie pamatytų ir sužinotų ką nors nauja. Šiuo atveju vèliavos nuleidimo ceremonija taip pat vyko dviejose vietose.

Karo muziejui buvo suteikta garbė tapti vieta, kur po kelionès aplink Lietuvą sugrižo Vytauto Didžiojo paveikslas. Rugsejoo $8 \mathrm{~d}$. Vytauto Didžiojo paveikslo sutikimo proga prie Laisvès paminklo pjedestalo buvo padetas paveikslas „Vytautas Didysis prie Juodụjų vandenų“. Aplink ji plevésavo véliavos, tarp kurių svarbiausia buvo Vytauto Didžiojo Sibiro bataliono vèliava. Šventėje dalyvavo daug svečių: Čekoslovakijos karininkai - brg. gen. F. Hrabčikas (František Hrabčik), gen. št. plk. ltn. L. Vitezas (Libor Vitez) ir K. Pražakas (K. Pražak), karo atašè Lietuvoje: Švedijos - rotmistras C. Juhlinas-Danfeltas (C. Juhlin-Dannfel), Prancūzijos - mjr. B. Ž. Šabanieras (Brevet Žan Šabanier), D. Britanijos mjr. A. Siuartas-Kochas (A. Stiuart-Koch), Vengrijos - mjr. G. Lanis, JAV - mjr. Džordžas R. Arnemanas (George R. Arnemen), Estijos - 
mjr. Ričardas Mazingas (Richard Masing), taip pat Estijos, Latvijos ir Suomijos spaudos atstovai. Laukdami, kol ineš Vytauto Didžiojo portretą, susirinkusieji klausėsi karo invalidų kanklèmis atliekamų muzikos kūrinių ir Šaulių choro dainų. Renginys buvo transliuojamas per garsiakalbius, tad viskas buvo girdèti net ir tolimiausiose Kauno centro gatvèse. Vytauto Didžiojo portretas buvo įneštas skambant iškilmingam maršui, atrodé, kad „tartum patsai Vytautas gyvas būtų ỉejęs“42.

Spalio 9 d. Karo muziejaus sodelyje, netoli Laisvès paminklo, buvo pastatytas „Juodasis paminklas“ 1920 m. spalio 7 d. Suvalkų sutarties sulaužymo faktui įamžinti. Šia proga surengtame minejjime kalbejjo prof. Mykolas Biržiška ir gen. ltn. V. Nagevičius, jie patikino, kad „Karo muziejuje jūs gedulo nepamatysite, nes Vilnius nèra miręs. Tik tada Karo muziejus pasipuoštų gedulu, jeigu kuri Vyriausybė jo atsižadètų ir pripažintų lenkams“. Paminklas buvo padarytas iš trijų metrų aukščio juodo, šlifuoto granito. Priekinejje jo pusejje buvo iškaltas užrašas: „1920-1930 V. D. m. Atmink, lietuvi, kad klastingas lenkas, pasirašęs Suvalkų sutartị 1920 m. spalio 7 d., jau po 2 dienų tą sutartị sulaužè ir pagrobė tavo sostinę Vilnių.“ Po šiuo užrašu buvo įmūrytas bronzinis Petro Rimšos medalis, vaizduojantis Zigmanto Augusto laikų lietuvišką pinigą su monograma ir lotynišku užrašu: „Qui habiat in coelisirridebit eos.“ („Tas, kuris gyvena danguje, juoksis iš jų.") Aplinkui ši pinigą buvo sukomponuotas ornamentas ir užrašas lenkų kalba: „Wolny z wolnymi, równy z równymi.“ („Laisvas su laisvais, lygus su lygiais.“) Toks buvo lenkų šūkis bendraujant su lietuviais. Kitoje paminklo pusèje buvo trumpas užrašas: „<...> ir eisime kovos keliu“, o po juo kitas P. Rimšos medalis, vaizduojantis Lietuvos vyčio kovą su ereliu.

Atidengiant paminklą muziejaus organizatorius pasakè: „Šis kuklus pažiūrèti paminklas turi didelę reikšmę. Po juo palaidoti dviejų tautų santykiai. Jis privalo mums priminti, kad kelias $\mathfrak{i}$ Vilnių eina ne per Varšuvą. Eidami vaduoti Vilniaus, mes privalome eiti tais keliais, kuriais ejjo Algirdas, Kęstutis, Vytautas. O jie vaikščiojo ne Vyslos, bet Dniepro, Bugo ir Pripetės pakrantèmis. Lenkas šaudo šiandien ukrainiečius, rytoj šaudys gudus, poryt lietuvius. Argi mes taip ir duosimés po vieną

42 Didžioji tautos šventè, Lietuvos aidas, Nr. 204, 1930 m. rugsëjo 9 d. 
iššaudomi? ${ }^{\text {" }}{ }^{43}$ Paminklo atidengimo ceremonija buvo baigta vèliavų nuleidimu. Šio paminklo pastatymas rodo, kad muziejaus vadovybè suprato Lietuvos žmonių lūkesčius, jų nerimą dèl Vilniaus netekties ir pritardami Vyriausybès politikai pastatė ši ženklą. Jis sodelyje stovejo tik iki $1938 \mathrm{~m}$. Lenkijos ultimatumo, po to buvo nuimtas ir pastatytas muziejaus viduje. 1930 m. lapkričio 4 d., rengiantis naujojo muziejaus kertinio akmens padejjimo iškilmèms, gen. ltn. V. Nagevičius Kauno savivaldybejje pristatė Karo muziejaus koncepciją. Jis pasakè: „Karo muziejai, dažniausiai susidarę iš ginklų ir amunicijos sandèlių (ceikhausų), kur ilgainiui buvo dedami ir karo troféjai, gyvenimo patenkinti negalèjo, todèl jie pavirto apžvalgos namais, o paskui Karo muziejais: a) tai ypač lengva pastebėti Berlyno karo muziejuje, kuris nevadinamas Karo muziejumi, Zeighaus, b) invalidų namai Paryžiuje (Hotels des Invalides) aiškiai rodo, kad tas pavadinimas nèra giminingas Karo muziejaus vardui, jis ten patalpintas tuose namuos (tikras Karo muziejus yra Bavarijos karo muziejus). " ${ }_{44}$

Generolas pateikè Lietuvos karo muziejaus viziją, kuri neatitinka minètų muziejų tipų. Pasak jo, kuriamas muziejus yra kitoks, nei tikras karo istorijos muziejus: „Jo uždaviniai yra žymiai platesni, susiję su Lietuvos praeitimi, kovomis dèl Lietuvos laisvès ir nepriklausomybès, be to, laiko moralius ryšius tarp kariuomenès ir visuomenès. <...> Karo muziejus nesitenkina tokia siaura savo paskirtimi, jis plačiai propaguoja Lietuvos nepriklausomybės gynimo reikalą ir gyvai atsiliepia $\mathfrak{x}$ visų svarbiausius Lietuvos nepriklausomybès reikalus per tautos šventes bei iškilmes. ${ }^{{ }_{45}}$ Todèl visi kilnūs Karo muziejaus uždaviniai yra glaudžiai tarpusavyje susiję, susikristalizavę ir virtę tradiciniais, nes Karo muziejus tapo tautos ir valstybės vienijimosi simboliu ir reikšmingu veiksniu. Buvo teigiama, kad naujasis Karo muziejus turi atitikti bendrą tautišką pobūdį, o paminklas „Žuvusiems už Lietuvos laisvę", varpų muzika ir tradicinès apeigos sudaryti naujai statomo muziejaus komplekso elementus, nes tai susiję su tradicijomis ir gyvenimu, todèl turi būti išsaugota aikšte prieš muziejų,

\footnotetext{
43 Klastingas lenkas savo sutartị sulaužè. Gen. Nagevičiaus kalba, atidarant „Juodąji paminklą", Karys, Nr. 42, 1930 -Vytauto D. - m. spalio 16 d.

${ }_{44}$ Pranešimas naujų Karo muziejaus rūmų statymo reikalu, KRVA, f. 219, ap. 1, b. 439, 1. 8 .

45 Vytauto Didžiojo muziejaus statymo klausimu pasitarimo protokolas, $1930 \mathrm{~m}$. lapkričio 4 d., ten pat, f. 219, ap. 1, b. 707, 1. 24.
} 
skirta iškilmėms ir apeigoms. Tokį muziejų matè jo kūrèjas ir puoselètojas, tačiau, kaip matyti iš istorinių faktų, atsitiko kiek kitaip.

1930 m. lapkričio 23 d. buvo ypatinga Karo muziejui. I Kariuomenès dienos minejjimo programą buvo įtrauktas Vytauto Didžiojo muziejaus kertinio akmens padejjimas. I iškilmes susirinko apie tris šimtus kviestinių svečių: prezidentas Antanas Smetonas, ministras pirmininkas Juozas Tūbelis, švietimo ministras Konstantinas Šakenis su žmonomis, vidaus reikalų ministras Petras Aravičius, Vytauto Didžiojo komiteto nariai, Kauno miesto burmistras Jonas Vileišis, karininkai ir įvairių organizacijų atstovai. Iškilmių metu Vytauto Didžiojo komiteto nariai ir prezidentas A. Smetona iškilmingai pasiraše kertinio akmens padejimo aktą. Dr. Juozas TumasVaižgantas pašventino akmenị ir pasakè kalbą: „Itin džiaugsminga valanda: tik ką Dievo ir Bažnyčios vardu man teko palaiminti vietą, kur stosis Karo ir Istorijos muziejus. <...> Jau tikrai turèsime Vytauto Didžiojo vardu Muziejų, kurio uždavinys liks tas pats kaip iki šio buvęs, Karo muziejus valstybiškumo ir pilietiškumo mokykla. Dar daugiau: būsimasis muziejus duos mums valstybejjimo bei pilietėjimo metodą: dabartị (Karo muziejų) jungs su praeitimi (istorija). <...> O praeities su dabartimi derintojas bus mums kaip buvęs, tik dar geriau, didysis politikas Vytautas." ${ }^{46}$

Po pašventinimo kalbėjęs prezidentas A. Smetona pabrèžè, kad „tatai darome Vytauto Didžiojo metais, to mūsų žemès ir mūsų tautos vado vardu. <...> Karo muziejaus kūrèjas yra padaręs pradžią tautos brangaus palikimo apsaugai. <...> Būsimasai muziejaus rūmas - mūsų tautos pasiryžimo ženklas gyventi ir tarpti, rišant praeiti su dabartim, saugoti savo laisvę visose žemès srityse, iš kurios penki akmens čionai padèti. Visos tautos léšomis, jos vaikų dosniomis aukomis išaugs mūsų muziejaus rūmai“" ${ }^{47}$. Baigęs kalbėti, prezidentas, skambant Vytauto Didžiojo giesmei, pasirašè aktą. Po to pasirašè aukštieji svečiai ir organizacijų atstovai. I muziejaus pamatus buvo įmūryti penki akmenys iš penkių Lietuvos sričių, kuriuos padejo penkių „karinių šeimų“ - Vyčio Kryžiaus ordino tarybos, Lietuvos kariuomenès kūrẻjų savanorių sąjungos, Lietuvos karo invalidų, Šaulių sąjungos ir Atsargos karininkų sąungos - atstovai.

\footnotetext{
46 Vytauto Didžiojo muziejui jau kertinis akmuo, Karys, Nr. 48, 1930 - Vytauto D. - m. lapkričio $27 \mathrm{~d}$.

47 Alm. Vytauto Didžiojo muziejus jau pradètas statyti, Lietuvos aidas, Nr. 268, 1930 Vytauto Didžiojo metai, lapkričio $24 \mathrm{~d}$.
} 
Akmenys buvo atvežti iš kovų su bolševikais, bermontininkais, lenkais, Klaipedos prijungimo ir Vilniaus vadavimo vietų. Prieš atliekant akmenų i̇mūrijimo ceremoniją, Vytauto Didžiojo komiteto pirmininkas K. Šakenis perkaitè aktą apie Vytauto Didžiojo muziejų-paminklą, kad „deda ši VYTAUTO DIDŽIOJO MUZIEJAUS kertini akmenį laikinojoje Lietuvos valstybès sostinejje Kaune ir, gaivindami savyje Tannenbergo Žalgirio NUGALĖTOJO narsiąją VALIĄ, ryžtasi atvaduoti lenkų pagrobtą savo sostinę Vilnių" ${ }^{48}$. Baigiantis ceremonijai, prezidentas A. Smetona plaktuku tris kartus sudave $\mathfrak{i}$ kertinị akmenị ir pasirode kibirkštis, simbolinis ženklas, „kad čia, šiame muziejuje, rusens amžinosios ugnies liepsnelë“49.

Muziejaus projektą parenge architektas prof. Vladimiras Dubenckis ir inžinieriai Karolis Reisonas ir Kazys Krikščiukaitis, pagrindiniai rangovai buvo broliai Dovydas ir Gedalis Ilgovskiai bei broliai Aronas ir Matas Sadinskiai. Vytauto Didžiojo muziejus buvo statomas už visuomenès aukas. Vytauto Didžiojo komitetas jas rinko ir taip finansavo statybą. $1932 \mathrm{~m}$. buvo surinkta puse milijono litų muziejaus statybai, bet pinigų vis tiek trūko, todèl vèl buvo išsiųsti kreipimaisi ị kariuomenès dalis, mokyklas, kitas ịstaigas. Rūmų statyba truko ketverius metus ir kèlè audringas diskusijas spaudoje ir visuomeneje, koks statusas ir priklausomybe turi būti ten ịkurdintų muziejų. Vytauto Didžiojo komitetas, svarstydamas Vytauto Didžiojo muziejaus koncepciją, pasiūle ịkurdinti po vienu stogu dar penkis muziejus: Čiurlionio galeriją, Miesto, Pedagoginį, Prekių pavyzdžiu ir Gamtos, tačiau didžiausias patalpas skirti Karo muziejui. Vèliau jau buvo kalba apie tris muziejus, kurie būtų pavaldūs Švietimo ministerijai. Tokie Vytauto Didžiojo komiteto siūlymai ir Karo muziejaus statuso ir priklausomybès pakeitimas sukèle didžiules diskusijas to meto spaudoje. Jose dalyvavo buvęs Lietuvos kariuomenès vadas gen. Silvestras Žukauskas, gen. št. plk. Stasys Raštikis, prof. Vincas Krèvè-Mickevičius. Pastarasis labai kompetentingai išsake savo nuomonę dèl muziejaus direktoriaus pareigybès: „Jeigu muziejus yra kūrybinè ịstaiga, jeigu jis turi tam tikras mokslo švietimo funkcijas, tai muziejaus direktoriaus pareigos yra labai sudètingos. <...> Kaip gali būti ịstaigos direktorius - ne specia-

${ }^{48}$ Jurevičiūtė A. Senojo muziejaus istorija, Vytauto Didžiojo karo muziejaus almanachas, 2006 metai, p. 43.

49 Alm. Vytauto Didžiojo muziejus jau pradètas statyti, Lietuvos aidas, Nr. 268, 1930 Vytauto Didžiojo metai, lapkričio $24 \mathrm{~d}$. 
listas? Kokias jis gali duoti nuorodas skyriaus viršininkams, jei jis reikalo neišmano? Nèra tokio žmogaus nei Europoje, nei Amerikoje. Kas gi bus toksai direktorius: manekenas? Iškamša su cilinderiu? Kam jis reikalingas: algai gauti ar muziejaus lankytojams kaliošus padavinèti?“

Rašytojas kritikavo Vytauto Didžiojo komiteto pateiktą muziejaus ìstatymo projektą, kurị rengè ne muziejininkai specialistai, nes „tvarkyti muziejų, ruošti jo ịstatymus, nesiskaitant su specialistų muziejininkų nurodymais - diletantizmas, kuris Lietuvos sąlygomis nieku gyvu neturi būti pateisinamas. Tai būtų greičiau ị nusikaltimą panašu“.

1934 m. lapkričio 21 d. buvo paskelbtas Karo muziejaus statutas, sudarytas iš 18 punktų. Pirmieji trys punktai skelbè: 1) Karo muziejus yra karo mokslo ir švietimo įstaiga; jo pirmas tikslas yra parodyti, kuriais būdais lietuvių tauta, besigrumdama su priešais, per amžius gynè savo laisvę. Jo antrasis tikslas yra ugdyti kariuomenèje bei visuomenèje tautinị susipratimą, tèvynès meilę ir pasiryžimą ginti Nepriklausomybę; 2) siekdamas pirmame paragrafe išvardintų tikslų, Karo muziejus apima visą laikotarpi, kuriame, pagal mokslo įrodymus, Lietuvoje gyventa lietuvių, o teritorijos atžvilgiu operuoja buvusios ir atgijusios Lietuvos valstybès plotais su sostine Vilniumi; 3) savo uždavinius vykdydamas, Karo muziejus renka, saugoja ir eksponuoja ịvairią tinkamai parengtą medžiagą, sistemingai suskirstydamas ją skyriais chronologine tvarka.

Muziejuje buvo numatyti šie skyriai: prosenovès ir ankstyvosios istorijos (aisčių kiltys, jų laisvès kovos, pilių fortifikacija ir ginklai); didžiųjų kunigaikščiu laikų; nuo Liublino unijos iki prijungimo prie Rusijos; Rusijos junge iki Nepriklausomybės paskelbimo (sukilimai, baudžiava, aušrininkai, varpininkai, Pasaulinis karas, vokiečių okupacija); kariuomenès kovų ir taikos meto skyrius (dalių ir įstaigu muziejai); karo operacijos (kautynių schemos, planai, modeliai); žuvusieji dèl Lietuvos laisvės; karo invalidai; savanoriai; Šaulių sąjunga; jūrų skyrius; šaltųjų ir šaunamųjų ginklų istorija su pavyzdžiais.

Statute buvo numatyta ir galimybė didinti arba mažinti skyrių skaičių. Muziejaus vadovo pareigos buvo pakeistos. Gen. ltn. V. Nagevičius buvo atleistas iš organizatoriaus pareigų ir paskirtas Karo muziejaus viršinin$\mathrm{ku}^{50}$. Remiantis statutu, iš karininkų buvo sudaryta muziejaus kolegija,

50 Karo muziejaus statutas, İsakymas kariuomenei Nr. 101, $₫ 3,1934$ m. spalio 27 d. 
kuri turèjo spręsti, kokios ekspozicijos turi būti, svarstyti kitus svarbius klausimus. Tarnautojų elgesi muziejuje apibrèžè Lietuvos kariuomenès vidaus tarnybos statutas. Muziejaus salių prižiūrètojai buvo pavadinti „tvarkūnais“. Šias pareigas beveik išimtinai ejo karo invalidai. Muziejuje buvo paliktas muziejaus orkestras ir jo kapelmeisteris. Tvarkūnų viršila, raštinès tarnautojai ir darbininkai buvo pavaldūs Administracijos skyriaus vedejjui, o muziejininkai specialistai - muziejaus viršininkui ${ }^{51}$.

1934 m. lapkričio 23 d. paminklas „Žuvusiems už Lietuvos laisvę" igavo dar didesnę sakralinę reikšmę - papédèje buvo iškilmingai palaidotas Nežinomas kareivis. Jo palaikai buvo atvežti iš kovų su bolševikais vietos Latvijoje, Červonkos kapinių. Iškilmès prasidejo 15 val. prie naujų Vytauto Didžiojo rūmų. Nežinomo kareivio karstas buvo padètas ant iš priešo paimtos patrankos ir uždengtas Vyčio Kryžiaus vèliava, kurios viename šone buvo Vyčio Kryžius, kitame - Gediminaičiu stulpai. Šonuose degè ugnies aukurai, o garbės sargyboje stovéjo karo invalidai, pèstininkų, artilerijos, kavalerijos, technikos dalių ir aviacijos atstovai. Visi paminklai sodelyje ir Laisvès varpas bei užrašas „Mes be Vilniaus nenurimsim“ buvo iliuminuoti. Iškilmèse dalyvavo prezidentas A. Smetona, vyriausybès, kariuomenès atstovai, garbūs svečiai iš Švedijos, aušrininkas Martynas Jankus, arkivyskupai Juozapas Skvireckas, Pranciškus Karevičius ir Lietuvos rytų apeigų (unitų) vyskupas Pranciškus Petras Būčys. Duobę pašventino Pranciškus Karevičius. Nežinomo kareivio karstą nešè krašto apsaugos ministras gen. Petras Šniukšta, vidaus reikalų ministras plk. Steponas Rusteika, gen. Silvestras Žukauskas ir gen. Jonas Jurgis Bulota. Muziejaus viršininkas gen. ltn. V. Nagevičius perskaite Respublikos Prezidento aktą dèl Nežinomo kareivio apdovanojimo III laipsnio Vyčio

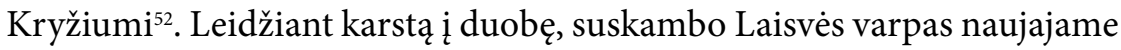
muziejaus bokšte ir trys šūvių salvès pasveikino laidojamą kareivị. Nežinomo kareivio palaidojimas prie paminklo „Žuvusiems už Lietuvos laisvę " dar labiau ịprasmino tą vietą, padarydamas ją svarbią ne tik Lietuvai, bet ir viso pasaulio kariams, nes gerbti Nežinomą karị yra visų valstybių tradicija, o ją Lietuvoje ịtvirtino Karo muziejaus viršininkas.

\footnotetext{
51 Ten pat.

52 Isakymas kariuomenei, Nr. 110, 1934 m. lapkričio $23 \mathrm{~d}$.
} 
Iškilmingas Karo muziejaus atidarymas Vytauto Didžiojo rūmuose ìvyko 1936 m. vasario 16 d. Ta proga „Laisvès“ ir „Žuvusiems už Lietuvos laisvę" paminklai ir Laisvès varpas buvo iliuminuoti tūkstančiais lempučių, penki prožektoriai apšvietė visą sodelị, Aviacijos skyriaus languose du prožektoriai apšvietė S. Dariaus ir S. Girèno nuotraukas. Pasibaigus iškilmėms prie paminklo „Žuvusiems už Lietuvos laisvę“, kviestiniai svečiai susirinko Vytauto Didžiojo karo muziejaus Didžiojoje saleje. Atidaryme dalyvavo prezidentas Antanas Smetona, ministras pirmininkas Juozas Tūbelis, arkiv. Juozapas Skvireckas, kariuomenès vadas gen. št. plk. Stasys Raštikis, Ministrų Kabineto nariai, užsienių valstybių svečiai, profesoriai, menininkai, spaudos ir visuomenès atstovai. Iškilmingu maršu sutikus valstybės prezidentą, muziejaus viršininkas brg. gen. V. Nagevičius pasakè atidarymo kalbą, kurioje apžvelgè muziejaus kūrimo istoriją ir jo veiklą per 15 metų. Jis pabrèžè, kad Karo muziejus, ịsikūręs tautos ir valstybės aukomis įrengtuose didinguose rūmuose, ir ateityje rodys, kaip lietuviai, per amžius budèję, laisvę laimèjo tik per aukas ir atsidavimą. Jo ekspozicijos ugdys kariuomenès ir visuomenès tautinị susipratimą, tèvynès meilę ir pasiryžimą ginti nepriklausomybę. Baigdamas kalbą, jis padèkojo visiems prisidejusiems prie muziejaus statybos: Vytauto Didžiojo komitetui, inž. Karoliui Reisonui, dr. Antanui Juškai, prof. Vaclovui Biržiškai, dail. Petrui Kalpokui, dail. Juozui Zikarui, ats. mjr. Petrui Ruseckui, kalbininkui Stasiui Dabušiui, ats. plk. Vaclovui Janavičiui, ats. plk. Petrui Bytautui, prof. Augustinui Janulaičiui, prof. Ignui Jonynui, prof. Antanui Saliui, dail. Jonui Mackevičiui, dail. Zigmui Petravičiui, inž. Zenonui Bačeliui, prof. Juozui Žemaičiui, dail. Stasiui Ušinskui ir skulptoriui Juozui Grybui, taip pat jauniesiems menininkams Vladui Jončiui, Vaclovui Kasčiuškai, Napoleonui Petruliui, Antanui Rūkštelei ir visiems savo bendradarbiams, kurie vienaip ar kitaip prisidejo prie muziejaus tvarkymo. Dalyvaujant arkivyskupui Juozapui Jonui Skvireckui, muziejų pašventino generalvikaras Kazimieras Steponas Šaulys. Prezidentas Antanas Smetona savo kalboje pabrèžè, kad „Karo Muziejaus organizavimas ir tvarkymas buvo atiduotas i prityrusio asmens gen. Nagevičiaus rankas, kad prityrusio tvarkytojo yra pralaužtas kelias, kuriuo galès laisvai eiti ir būsimieji nauji karo muziejaus šeimininkai. Ši vieta yra itin brangi kiekvienam lietuviui. Ji, tarytum nerašyta istorija, byloja apie garbingą tautos praeitị ir kovas dèl laisvès“. Ivertindamas brg. gen. V. Nagevičiaus nuopelnus Karo muziejaus organizavimo darbe ir muziejaus atidarymo proga, 
1936 m. vasario 16 d. Prezidento aktu Nr. 392 brg. gen. V. Nagevičius buvo apdovanotas Vytauto Didžiojo II laipsnio ordinu ${ }^{53}$. Po atidarymo ir pašventinimo iškilmių visi buvo pakviesti apžiūrèti naujųjų Karo muziejaus salių ir skyrių.

Lietuvos kariuomenès aukštieji karininkai buvo ịtraukti ị Karo muziejaus koncepcijos kūrimą ir iggyvendinimą. Dalis jų dirbo Karo muziejaus kolegijoje, kuri daug dèmesio skyrè naujų ekspozicijų įrengimui. Savo posėdžiuose ji svarstė, kas turi būti rodoma ir kaip tai padaryti. $1935 \mathrm{~m}$. birželio 8 d. kolegijos nariai, igulos viršininkas, divizijos vadas gen. ltn. Julius Čaplikas, aviacijos viršininkas inžinierius plk. Antanas Gustaitis, Ginklavimo valdybos viršininkas gen. ltn. Motiejus Pečiulionis, kariuomenès intendantas plk. Kazys Navakas, karo technikos viršininkas gen. Itn. Klemensas Popeliučka, kavalerijos viršininkas gen. št. plk. Juozas Tallat-Kelpša, Generalinio štabo kursų lektorius gen. št. plk. Stasys Zaskevičius, Spaudos ir švietimo skyriaus viršininkas plk. Juozas Šarauskas, Karo butų skyriaus viršininkas, inžinierius plk. Juozas BarzdaBradauskas, dalyvaujant pakviestam Šaulių sąjungos skyriaus tvarkymo komisijos pirmininkui Antanui Graurokui, pirmininkaujant Karo muziejaus viršininkui gen. ltn. V. Nagevičiui ir sekretoriaujant Karo muziejaus konservatoriui, administracijos mjr. Petrui Šeštakauskui, svarste, kokie eksponatai atspindètų pulko istoriją ir kaip jų būtų galima ịsigyti. Nuspręsta, kad reikia padaryti pulkų šefų gipsinius biustus - juos pagamins muziejus, o tapytą paveikslą užsakys ir iš savo lešsu nupirks kiekvienas pulkas. Pulko ekspozicijoje turèjo būti tapytas pulko vado, steigejjo ir pasižymejjusių kovose vadų tapyti portretai (mažesnio formato), kitų vadų fotografijos būtų laikomos albumuose. Šiose ekspozicijose buvo numatyta eksponuoti buvusias pulkų vẻliavas, mūšio lauke paimtus trofẻjus, kautynių schemas, planus, modelius, svarbesnius įsakymus, jų ištraukas, karių grupines nuotraukas, ịvairių pulko istorijos epizodų tapytus paveikslus ir kt. Aviacijos skyriuje buvo nuspręsta patalpinti Antano Gustaičio konstrukcijos lèktuvą ANBO I ir įrengti ne tik Aviacijos skyrių, bet ir atskirą "Lituanicos" salę, skirtą S. Dariaus ir S. Girèno skrydžiui nušviesti. Joje, atskiroje vitrinoje, buvo planuojama eksponuoti „Lituanicos" likučius ( $10 \mathrm{~m}$ ilgio, 5 ir $4 \mathrm{~m}$ pločio ir $3 \mathrm{~m} 20 \mathrm{~cm}$ aukščio), individualių priemonių vitrinoje - grafiškai nubraižytą skrydžio Niujorkas-

${ }^{53}$ Isakymas kariuomenei Nr. 14, $1936 \mathrm{~m}$. vasario $29 \mathrm{~d}$. 
Kaunas schemą, kitose vitrinose - straipsnius apie skrydi ir fotografijas. Šiomis ekspozicijomis rūpinosi muziejaus Aviacijos skyriaus tvarkymo komisija, vadovaujama mjr. Antano Mačiuikos.

1937 m. vasario mėn. jau buvo pagamintos vitrinos „Lituanicos“ likučiams ir asmeniniams lakūnų daiktams laikyti, padarytos drobės, kuriose buvo surašytos skrydžiui aukojusiųjų pavardès, pagaminti $5 \mathrm{~m}$ ilgio žemynų kontūrai ant sienos, vaizduojantys skrydžio trajektoriją, ir vitrina, kurioje būtų padèti abu „Lituanicos I“ ir „Lituanicos II“ modeliai. Šioje salejje buvo eksponuojama ir Felikso Vaitkaus skrydžio trajektorija, taip pat jo lèktuvo modelis. Komisija kartu rengè ir Aviacijos skyrių: buvo pakabintas ANBO I, pagaminti 7 aviacinių bombų modeliai, dalis jų buvo eksponuojama Priešlèktuvinès apsaugos skyriuje.

Dar 1934 m. spalio 15 d. už 3000 Lt buvo įsigyta Vinco Grybo skulptūra „Vytautas Didysis“. Ji papuošè kuriamą Vytauto Didžiojo kapelą, buvo pastatyta jos nišoje, o jos šonuose vèliau buvo įrengti vitražai, vaizduojantys Žalgirio mūšyje paimtą 51 nugalètų kryžiuočių vẻliavą. Kapelos sienas papuošė paveikslai, susiję su Vytautu Didžiuoju: „Vytauto priesaika“, „Vytautas prie Juodosios jūros“, „Vytautas prie Naugarduko“, „Totorių chano duoklè Vytautui“ - ir kitais svarbiais Lietuvos istorijos ịvykiais, tokiais kaip Saulès mūšis, Lucko suvažiavimas, Žalgirio mūšis, Liublino unija. Kapelos viršuje buvo sukabinti Lietuvos didžiųjų kunigaikščių ir Lietuvos Respublikos prezidentų portretai, juos skyrè erškéčių vainikas, ženklinantis 1795-1918 m. - rusų priespaudos laikotarpi.

Gen. ltn. V. Nagevičius, siekdamas ịsigyti Lietuvos istorijai svarbių eksponatų, bendradarbiavo su Švedijos ir Vokietijos muziejais. Jis pats buvo lankęsis daugelyje Europos karo muziejų ir pasinaudojęs jų gerąja patirtimi. Eksponatų issigijimo klausimais daug jam padejo diplomatas Ladas Natkevičius, nuo 1934 m. paskirtas Lietuvos pasiuntinybės Prancūzijoje patarejuu ir dirbęs ten iki 1939 m. Tuo metu jis gerokai pasidarbavo kaupdamas Karo muziejaus istorinių paveikslų kolekciją. $1935 \mathrm{~m}$. Ladas (Vladas) Natkevičius Paryžiuje pamatė dailininko Jano Stykos paveikslą „Vytauto priesaika“, jị muziejus įsigijo 1937 m. iš jo žmonos Liucijos už 12000 Lt. Ši vertingą pirkinị ịsigyjant tarpininkavo ir tuo metu Paryžiuje buvę generolai Zenonas Gerulaitis ir Motiejus Pečiulionis. Paveikslui pasiekus Lietuvą, muziejaus viršininkas laiške L. (V.) Natkevičiui rašè: „Šio paveikslo pirkimą laikau vienu didžiausių Karo muziejaus 
laimèjimų, o to laiméjimo kaltininku laikau Tamstą.“ Isigijęs „Vytauto priesaiką", brg. gen. N. Nagevičius norẻjo muziejuje turèti taip pat Jano ir Tado Stykų Žalgirio mūšio panoramą. Paveikslai buvo ịsigyti ir $1937 \mathrm{~m}$. spalio pabaigoje atplukdyti $\mathfrak{i}$ Lietuvą. Reikšdamas padèką L. (V.) Natkevičiui už ịsigytus paveikslus, muziejaus viršininkas rašè: „Žalgirio mūšio paveikslai visumoj sudaro gražios ir galingos kompozicijos ịspūdị. Mūsų meno mokyklos profesūra ir vyresniụjų skyrių mokiniai yra tiesiog sužaveti, o ir aš labai ir labai patenkintas." Jano ir Tado Stykų paveikslų, vaizduojančių svarbius Lietuvos ịvykius, nupirkimas buvo labai reikšmingas ìvykis 4-ojo dešimtmečio muziejaus istorijoje.

Visuomené, lankanti naujojo muziejaus sales, pareiškè pageidavimą jose rasti suolų, ant kurių galima būtų pailsèti ir pasigrožèti ekspozicijomis. Ṣ̌ lankytojų pageidavimą muziejaus administracija greitai išpildè. Jau $1936 \mathrm{~m}$. rudeni Vlado Budrikio firma pagamino 6 suolus pagal dailininko Gerardo Bagdonavičiaus ir 18 suolų pagal inžinieriaus K. Reisono projektus. Be to, buvo pagamintas vienas apvalus suolas Didžioje muziejaus saleje stovinčiai palmei apjuosti. Muziejus pasipildè ne tik naujais baldais, bet ir eksponatais. $1936 \mathrm{~m}$. iš dailininko J. Mackevičiaus buvo įsigyta 11 aušrininkų ir žymesniųjų karininkų paveikslų po $80 \mathrm{Lt}$ už kiekvieną, o iš dailininko Rudolfo - didelį batalinę sceną vaizduojantị paveikslą „1 p. p. štabas kautynių metu prie Radviliškio" už 500 Lt, iš Z. Petravičiaus - „Lietuvių demonstracija Tomske“, „Kariūnų pakèlimas i karininko laipsnị “, „Pionieriai stato tiltą“ ir „4 p. p. artinasi prie Vilniaus“, iš Zofijos Kochanauskienès - paveikslą „Noimano ir Zaso byla“ už 2000 Lt. Viktoras Vasiljevas pagamino Impilties piliakalnio skersinio pjūvio maketą.

Rengiant knygnešių ekspoziciją buvo atliktas didelis tiriamasis darbas. Petras Ruseckas surinko 77 knygnešiu biografijas ir nuotraukas ir ịrengè Vyriausiojo Lietuvos gynimo komiteto ekspoziciją. Plk. P. Bytautas vadovavo rengiant ginklų ekspoziciją. Tais pačiais metais iš Rietavo Oginskių dvaro buvo atvežta palmé, padaryta žirgo iškamša ir iš Juozo Timuko ịsigyta nemažai fotografijų. Fotografijos su muziejaus vaizdu buvo parduodamos po $30 \mathrm{ct}$. Bilietas naujojo muziejaus lankytojui kainavo 20 arba 50 ct. $1936 \mathrm{~m}$. lapkričio mèn. už bilietus buvo gauta $5750 \mathrm{Lt}$. Nuo 1936 m. vasario 16 d. iki 1937 m. sausio 1 d. muziejų aplankè 61536 žmonès: su ekskursijomis - 12 601, pavieniai - 48935.

Dar vienas svarbus ir daug jègų bei ryžto iš muziejaus kolektyvo pa- 


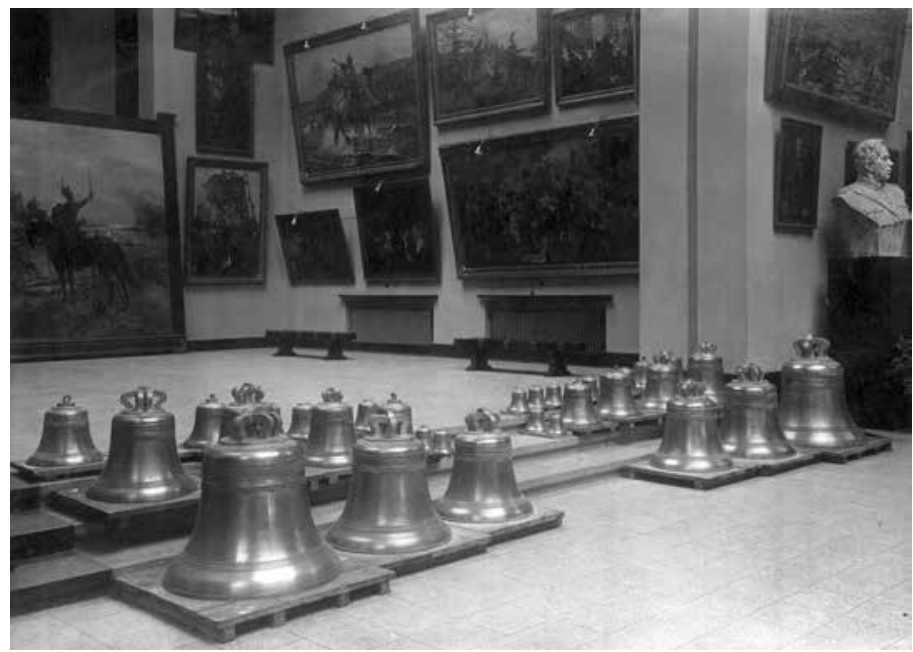

35 kovų

varpai

Vytauto

Didžiojo

karo

muziejaus

Didžiojoje

salèje prieš

¡keliant juos

i muziejaus

bokštą.

$1938 \mathrm{~m}$.

rugsèjo $8 \mathrm{~d}$.

N-801

reikalavęs darbas buvo varpų muzikos sistemos įsigijimas. $1935 \mathrm{~m}$. kovo 13 d. gen. ltn. V. Nagevičius kreipèsi ị Lietuvos atstovą Briuselyje Vytautą Gyli dèl firmoje „Michele Clochnes Taurnai“ 28 varpų, muzikos volo, klaviatūros pagaminimo ir kitų varpų - Laisvès varpo ir laikrodžio varpo - sumontavimo Karo muziejaus bokšte. Varpų muzikos ịranga muziejui kainavo 29 373, o jos sumontavimas - 11 806,21 Lt. Belgijos firmai buvo sumokèta 37 077,45 Fr (Belgijos frankų). Mažai žinomas Lietuvos visuomenei faktas, kad visi varpai, kurie yra Karo muziejaus bokšte, turi vardus, nes pagal varpų liedinimo tradicijas kiekvienas varpas turi ji turèti. Vardai buvo užrašyti ant šių varpų: 1-o - Vilnius, 2-o - Klaipéda, 3-io - Kédainiai, 4-o - Alytus, 5-o - Panevėžys, 6-o - Radviliškis, 7-o Zarasai-Dauguva, 8-o - Seinai-Augustavas, 9-o - Širvintos-Giedraičiai, 10-o - Kürèjas savanoris, 11-o - Partizanas-Šaulys, 12-o - Vilniaus kovotojas, 13-o - Klaipédos vaduotojas, 14-o - Amerikos lietuvis kovotojas, 15-o - Gediminenas (1 pèst. pulk.), 16-o - Algirdenas (2 pèst. pulk.), 17-o - Vytauténas (3 pèst. pulk.), 18-o - Mindaugènas (4 pèst. pulk.), 19-o - Kęstutènas (5 pèst. pulk.), 20-o - Margènas (6 pèst. pulk.), 21-o Butegeidenas (7 pèst. pulk.), 22-o - Vaidotenas (8 pèst. pulk.), 23-io - Vytautenas (9 pèst. pulk.), 24-o - IV divizijos karys, 25-o - Karo mokyklos karys, 26-o - Gudas karys, 27-o - Aviatorius, 28-o - 1 art. pulk. karys, 29-o - 2 art. pulk. karys, 30-o - 3 art. pulk. karys, 31-o - 4 art. pulk. karys, 
32-o - Husaras Radvilènas, 33-io - Ulonas Birutènas, 34-o - Geležinio Vilko pulko dragūnas, 35-o - Karys technikas. Visų varpų vardai buvo susiję su kariuomene - jos kovomis ir pergalèmis, ginklų rūšimis.

1937 m. sausio 15 d. buvo iškilmingai paminèta Klaipėdos prijungimo diena. Iškilmès prasidejo muziejaus sodelyje, padedant gèlių prie paminklo „Žuvusiems už Lietuvos laisvę“ ir stebint pražygiuojančius šaulius Donelaičio gatve. Renginyje dalyvavo krašto apsaugos ministras plk. Stasys Dirmantas, kiti aukšti karininkai, visuomenès atstovai, Mažosios Lietuvos patriarchas Martynas Jankus ir politikos veikejas Reizgys. Pasibaigus iškilmėms sodelyje, visi susirinko Karo muziejuje minejjimo pratęsti. Kalbas pasakè krašto apsaugos ministras plk. Stasys Dirmantas, Martynas Jankus, Reizgys, Lietuvos kariuomenès kūrèjų savanorių sąjungos pirmininkas Petras Gužas, Tautininkų sąungos gen. sekretorius Simas Janavičius, Jaunosios Lietuvos vadas Benediktas Grébliauskas-Grèbliūnas. Paskaitą apie Klaipėdos prijungimą perskaitė gen. št. plk. Stasys Zaskevičius. Minejjime koncertavo muziejaus orkestras, kuriam dirigavo Balys Dvarionas. Panašūs renginiai, skirti iškilioms Lietuvos istorijos datoms paminèti, naujajame muziejuje buvo dažni. Čia savo susirinkimus ir suvažiavimus rengè Savanorių, Kariuomenès pirmūnų, Karo invalidų sąjungos, vyko gydytojų kongresai ir kiti renginiai.

Vienas paskutinių didelių darbų, atliktų ̇amžinat žuvusiụjų atminimą, - Žuvusiujjų kriptos įrengimas muziejaus viduje. Brg. gen. V. Nagevičius 1937 m. kovo 13 d. kreipèsi ił Varpų vardų parinkimo komisiją, kad ji svarstytų jo pasiūlymą dèl žuvusiųjų už Lietuvos laisvę įamžinimo. Komisija, susirinkusi i posėdi kovo 20 d., nutarè, kad reikia Karo muziejuje ịrengti Žuvusiųjų kriptą, ir numate jai vietą rūsio patalpoje. Žuvusiųjų kriptos autorius buvo dailininkas Stasys Ušinskas. Pritardama projektui, komisija pabrěže jo svarbą kariuomenei ir visuomenei, prisimenant ir j̇amžinant žuvusiųjų ir mirusiųjų nuo žaizdų auką. Kripta turinti būti „impozantiška ir monumentali“ “54. Laikantis šios koncepcijos ir buvo įrengiama Žuvusiujų kripta. Jos sienos buvo padengtos juodu dirbtiniu marmuru, nišose pakabintos balto marmuro lentos, kuriose paauksuotomis raidèmis buvo užrašytos žuvusiụjų ir mirusių nuo žaizdų pavardès abėcèlès tvarka, pagal karines dalis, kuriose jie tarnavo. Kriptos galinèje sienoje

54 Kovų varpams vardų parinkimo komisijos protokolas. 1937 m. kovo 20 d., LCVA, f. 1764 , ap. 1, b. $267,1.2$. 


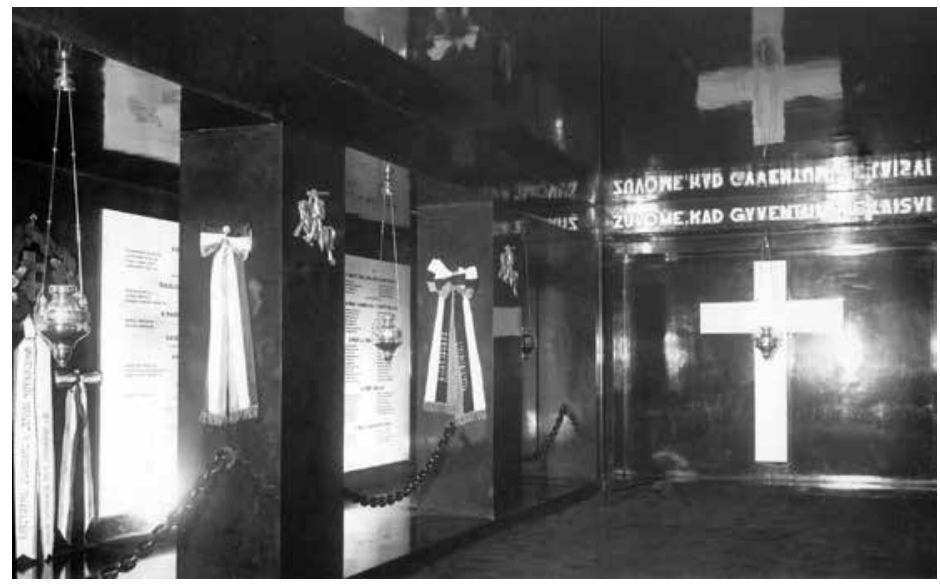

Žuvusiųjų už

Lietuvos laisvę skyrius Žuvusiųjų kripta. Atidaryta $1938 \mathrm{~m}$. lapkričio $23 \mathrm{~d}$.

buvo pakabintas didelis balto marmuro kryžius su užrašu viršuje „Žuvome, kad jūs gyventumète laisvi“ ir skaičiais „1918-1923“. Prie kolonų buvo pritvirtinti paauksuoti šeši Vyčiai ir šeši Vyčio kryžiai. Tarp kolonų, ant grandinių, buvo pakabinti 8 lampionai, pagaminti iš $1 \mathrm{~mm}$ storio žalvarinès skardos ir paauksuoti. Viduje buvo ịdètas mèlynos spalvos stiklas. Vienas lampionas kainavo 370 Lt. Žuvusiųjų pavardes, numatytas užrašyti lentose, pateikè kiekviena karinè dalis ir sumokèjo už raidžių pagaminimą ir pritvirtinimą. Dèl raidžių auksavimo kreiptasi ị Valiutų komitetą ir tam gauta 100 aukso rublių. Raidès buvo nuo 1,5 iki $2 \mathrm{~mm}$ dydžio ir visos kainavo 27549 Lt. Kriptos grindys buvo išklotos kilimu, kad vaikščiojant nebūtų keliamas triukšmas ir netrikdytų žuvusiųjų ramybės.

Iškilmingas kriptos atidarymas ịvyko 1938 m. lapkričio 23 d., ją pašventino kapelionas A. Sabaliauskas. Ant 16 kablių, pritvirtintų prie kolonų, buvo pakabinti vainikų kaspinai ir sidabriniai vainikai. Po atidarymo muziejuje įvyko iškilmingas Kariuomenès dienos ir Vyčio Kryžiaus ordino šventès minejjimas ir simfoninio orkestro koncertas. 1938 m. lapkričio 23 d. muziejaus bokšto nišoje buvo pastatyta skulptoriaus Jono Mikėno sukurta bronzinè 2,65 m aukščio Vytauto Didžiojo laikų kario figūra, kainavusi 5500 Lt. Tą dieną buvo atidengti gen. Silvestro Žukausko ir Šaulių sąungos vado Vlado Putvinskio biustai.

1938 m. vasario $16 \mathrm{~d}$. buvo švenčiamas Nepriklausomybès 20-metis. Didžiausios iškilmės vyko Vytauto Didžiojo karo muziejaus sodelyje. Čia 
atvyko prezidentas A. Smetona, Vyriausybės nariai, kariuomenės vadovybė, kitų valstybių atstovai, Seimo nariai. Prie Nežinomo kareivio kapo stovejo vèliavininkai, o visas sodelis buvo pilnas karių, šaulių, studentų, moksleivių, miesto gyventojų. Orkestrui grojant Gedulingą maršą buvo padèta gèlių prie paminklo „Žuvusiems už Lietuvos laisvę“. Po to kalbèjo ministras pirmininkas Jokūbas Stanišauskas. Ministro pirmininko kalbos pabaigoje, gaudžiant Laisvès varpui ir visų bažnyčių varpams, buvo sugiedotas Tautos himnas. Iškilmių pabaigoje nugriaudejo patrankų šūviai, skirti jubiliejui pagerbti, vyko kariuomenès, Šaulių ir kitų organizacijų vèliavų paradas. Po to Karo muziejuje Karininkų ramovè surengè iškilmingą posedic. Jame dalyvavo krašto apsaugos ministras brg. Stasys Dirmantas, kariuomenès vadas brg. gen. Stasys Raštikis, štabo viršininkas brg. gen. Jonas Černius, Kauno iggulos karininkai, kitų valstybiu kariuomenių atstovai. Prof. Augustinas Janulaitis skaite paskaitą apie Lietuvos praeiti ir dabarti. Ta proga muziejuje buvo pristatytas neseniai isigytas paveikslas „Vytautas Naugardo žemèje“, o muziejaus viršininkas brg. gen. V. Nagevičius papasakojo apie Vytauto Didžiojo laikus.

1938 m. gruodžio 12 d. Astravo dvaro savininkas grafas Jonas Tiškevičius padovanojo Vytauto Didžiojo karo muziejui dvi ketaus skulptūras liūtus - ant akmeninių postamentų. Jos gruodžio $28 \mathrm{~d}$. buvo pastatytos prie ièjimo ị Karo muziejų ir iki šiol puošia jo prieigas.

1939 m. muziejaus sodelyje buvo pastatyti paminklai pirmiesiems žuvusiems Nepriklausomybès kovose - kariui Povilui Lukšiui ir karininkui Antanui Juozapavičiui ir perkelti ị kitą vietą Martyno Jankaus ir Simono Daukanto biustai.

\section{MUZIEJAUS VEIKLA OKUPACIJŲ METAIS}

1940 m. birželio 25 d. buvo panaikintas Vytauto Didžiojo karo muziejaus pavadinimas ir jis pavadintas Kariškai istoriniu muziejumi. Jo viršininkas brg. gen. Vladas Nagevičius tą pačią dieną buvo atleistas iš pareigų, o ị jo vietą paskirtas plk. Juozas Šarauskas. Prie jo paskirtas politinis vadovas Bronius Žekonis. $1941 \mathrm{~m}$. vasario $5 \mathrm{~d}$., muziejų perèmus Švietimo komisariatui, jis buvo paskirtas direktoriumi.

Jau pirmosiomis okupacijos dienomis buvo uždraustos Nežinomo ka- 
reivio pagerbimo apeigos. Paskutinị kartą jos vyko 1940 m. birželio 26 d., kai Liaudies vyriausybės ministras pirmininkas Vincas Krèvè-Mickevičius vyriausybès vardu padejjo vainiką ir pasakè kalbą: „Pirmieji mūsų žingsniai, kurie visai Lietuvai yra simbolis nepriklausomos Lietuvos. Prie šito kapo, kuris kaip ir liudija mums visas tas kovas už Lietuvos liaudies gerovę, mes duosime pažadą, kad rūpinsimès ịvykdyti visa tai, už ką šis kareivis žuvo ir paaukojo savo gyvybę: liaudies gerovè, visos Lietuvos gerovė ir visos Lietuvos gyventojų gerovè. Tai yra mūsų darbo simbolis, ir už tuos idealus, už kuriuos žuvo pirmieji kovotojai - už Lietuvą, laimingą, nepriklausomą, mes kovosime ir jos naudai dirbsime. ${ }^{\text {“55 }}$

Tačiau žodžiai labai skyrèsi nuo darbų. Beveik po metų, 1941 m. birželio 4 d., buvo nuimti du biustai - kareivio Povilo Lukšio ir karininko Antano Juozapavičiaus. Už ši darbą Pranui Baleniūnui buvo sumokèta $310 \mathrm{Rb}^{56}$.

1940 m. rugpjūčio 1 d. Tautinè vèliava, o rugpjūčio 3 d. - Valstybès vèliava buvo pakeistos ị sovietines raudonas. Sovietų okupacija vertè muziejaus vadovybę keisti ne tik vėliavas, keliamas virš muziejaus pastatų, bet ir ekspozicijų tematiką. $1940 \mathrm{~m}$. liepos 19 d. raporte krašto apsaugos ministrui muziejaus viršininkas plk. Juozas Šarauskas pateikè tokią ekspozicijų schemą: „a) prosenovès ir ankstyvoji istorija (aisčių kiltys, jų laisvės kovos, pilių fortifikacija, ginklai); b) didžiųjų kunigaikščių laikai; c) laikai nuo Liublino unijos iki prijungimo prie Carinès Rusijos; d) lietuvių gyvenimas Rusijos caro junge iki nepriklausomybès paskelbimo (sukilimai, baudžiava, aušrininkai, varpininkai, Vilniaus seimas, pasaulinis karas, vokiečių okupacija); e) Lietuvos kariuomenès kovos su reakcionieriaus Pavelo Rafalovičiaus Bermonto-Avalovo kariuomene ir kovos su imperialistinès Lenkijos kariuomene (kautynių schemos, planai, paveikslai, fotografijos); f) kariuomenès dalių skyriai; g) karo operacijos (kautynių schemos, planai, modeliai); h) žuvusieji dèl Lietuvos laisvės; i) karo invalidai; j) savanoriai k) Šaulių sąunga; l) jūros skyrius; m) ašmeninio ir šaunamojo ginklo istorija pavyzdžiais.“ Taip pat pranešè ministrui, kad jau rengiamas naujas skyrius - „Draugingoji mums SSRS Raudonoji armija“,

\footnotetext{
55 Liaudies vyriausybè pagerbė Nežinomo kareivio kapą, Lietuvos aidas, 1940 m. birželio 27 d., nr. 301.

56 Irašas apie apmokètą sąskaitą Pranui Baleniūnui, Kariškai istorinio muziejaus einamujų sąskaitų knyga 1941-1942 m., l. 17.
} 
kuriame bus nušviečiamas Lietuvos sostinès išvadavimas Raudonosios armijos jègomis ir grąžinimas 1939 m., ịžengimas i Lietuvą ir draugiškas bendradarbiavimas su Liaudies kariuomene.

Pasikeite ir muziejaus fasadas. Virš muziejaus jau plevėsavo raudona vèliava. Netrukus muziejui buvo priskirtas politinis vadovas Bronius Žekonis, kuris greitai pakeite trumpai dirbusį muziejaus viršininku plk. J. Šarauską. Tuo pat metu muziejaus rinkinius papildè likviduojamos kariuomenès pulkų, Šaulių sąungos ir Savano-

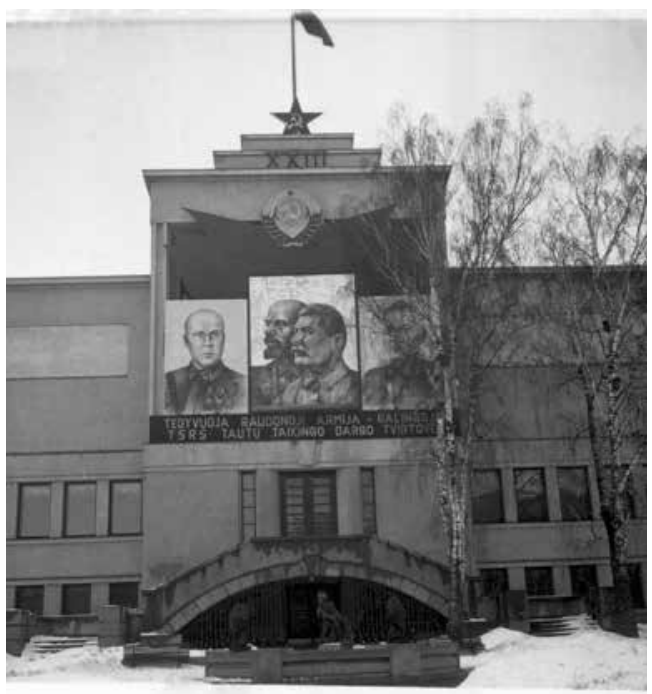
rių sąjungos vèliavos, šių organizacijų prizai, suvenyrai ir kt. Sovietai uždraudè kelti Lietuvos valstybės vèliavas. Tuo metu virš bokšto ir muziejaus plevésavo raudona vèliava. Neleido atlikti Tautos himno, Mažosios Lietuvos himno, giesmès „Marija, Marija“ ir kitų lietuviškų melodijų, kurias skambindavo varpai. Pertvarkymų būta ir muziejaus ekspozicijose. İsakyta pašalinti visus paveikslus, vaizduojančius lietuvių kovas su bolševikais 1918-1919 m. Žuvusių Lietuvos karių kripta nepaliesta, ją tik uždarè. Taip pat buvo numatyta uždengti Vytauto Didžiojo statulą muziejaus Vytauto kapeloje ir prieš ją pasatyti Stalino arba Lenino statulą, o vietoje užrašo Didžiosios salès viršuje „Per amžius budèję, laisvę laimejom per aukas ir pasišventimą“ užrašyti: „Raudonoji armija - galingoji tautų taikingo darbo tvirtove. ${ }^{\text {“57 }}$ To nebuvo padaryta nei per pirmąją sovietų, nei per nacių okupaciją. Antrosios sovietų okupacijos metu ši klaida buvo „ištaisyta“-

57 Matulionis B. Karo muziejus - didysis gen. gyd. Vl. Nagiaus Nagevičiaus kūrinys, Vladas Nagius Nagevičius, Putnam, 1962, p. 155. 
senasis užrašas panaikintas, atkurtas tik po Kovo 11-osios.

Vietoje istorinių paveikslų, kurie kabojo kapeloje, buvo įsakyta pakabinti Josifo Stalino, Vladimiro Lenino, Viačeslavo Molotovo, Semiono Timošenkos, Justo Paleckio ir kitų bolševikų (tiek rusų, tiek lietuvių) portretus. Tai padaryti nebuvo taip lengva. Tuos portretus reikejjo turèti. Tad beveik visą tą okupacinị laikotarpi buvo bandoma juos nutapyti ar atsisiųsti iš Sovietų Sąungos. $1941 \mathrm{~m}$. sausio 3 d. buvo sumokèta $1300 \mathrm{Rb}$ dailininkams Mykolui Labuckui ir Vytautui Kasiuliui už Lenino portreto nutapymą ${ }^{58}$. Per pirmosios sovietų okupacijos metus buvo ịsigytos šios litografijos: V. Molotovo, V. Lenino, J. Stalino, S. Vorošilovo, S. Timošenkos, K. Markso, F. Engelso; tapyti paveikslai: J. Paleckio „Caricino gynimas“, „Stalinas ir Vorošilovas Kremliuje“, „Stalinas ir Leninas prie tiesioginio laido“, „Leninas Petrapilyje“, portretai: V. Lenino, J. Stalino, S. Timošenkos, V. Molotovo, fotonuotraukos: „Lietuvos Seimo delegacijos sutikimas Maskvoje ir J. Paleckio kalba“ ir „Lietuvos Liaudies Seimo delegatai Aukščiausiosios Tarybos kuluaruose Maskvoje“, biustai: V. Lenino, J. Stalino, S. Vorošilovo ${ }^{59}$. J. Stalino ir S. Vorošilovo gipsinius biustus muziejus nusipirko iš Bernardo Bučo už $5000 \mathrm{Rb}$ (už kiekvieną po $2500 \mathrm{Rb}$ ) ${ }^{60}$. S. Vorošilovo portretą nutapè Jonas Mackevičius, kuriam buvo sumokèta $1000 \mathrm{Rb}^{61}$. Isigyjamų paveikslų meniniam lygiui nustatyti buvo sudaryta komisija, ị ją LSSR dailininkų sąjunga delegavo Stasị Ušinskị, Leonardą Kazoką, Ireną Trečiokaitę, Povilą Kaufmaną ir Zalę Bekerį. Jie 1940 m. rugpjūčio 28 d. dalyvavo Karo muziejaus užsakytų J. Stalino, V. Molotovo ir S. Timošenkos portretų prièmime ${ }^{62}$. Vladas Grybas pagamintą J. Stalino skulptūros modelị atsiuntè muziejaus vadovybei $1941 \mathrm{~m}$. sausio $19 \mathrm{~d} .^{63}$

58 Irašas apie atsiskaitymą už parduotą dekoratyvinį Lenino portretą, tapytą aliejiniais dažais ant drobès, Kariškai istorinio muziejaus einamujų sąskaitų knyga 1941-1942 m., 1. 2 .

59 Iš Vytauto Didžiojo karo muziejaus perimtų eksponatų sąrašas, $1942 \mathrm{~m}$. birželio $18 \mathrm{~d}$., Vytauto Didžiojo karo muziejaus rinkiniai (toliau - VDKM), Pagalbinis fondas, b. 3, 1. 24. ${ }^{60}$ Irašas apie apmokètą sąskaitą, Kariškai istorinio muziejaus einamujų sąskaitų knyga 1941-1942 m., 1. 9.

61 Irašas apie išmokètus pinigus Jonui Mackevičiui, ten pat, 1. 11.

62 Igaliojimas LSSR Dailininkų sąjungos, 1940 m. rugpjūčio 26 d., VDKM rinkiniai, Pagalbinis fondas, b. 3, 1. 85.

${ }^{63}$ Irašas apie atsiųstą draugo Stalino skulptūros modelị, darytą V. Grybo, pagal kvitą sausio 25 d., Kariškai istorinio muziejaus einamujų sąskaitų knyga 1941-1942 m., 1. 3. 
Nukentejo ir paskutiniais nepriklausomos Lietuvos metais įrengta paminklinè „Knygnešių sienelë“. Bolševikai liepe nudaužyti visas joje iškaltas knygnešių pavardes. Tačiau buvo pasielgta labai gudriai. Div. gen. Stasys Raštikis savo atsiminimuose rašè: „Muziejaus vadovybe pridengé tuos parašus lentomis ir tas lentas aptaškè cemento skiediniu. Bolševikai buvo apgauti, nes nežinančiam atrode, kad knygnešių pavardès panaikintos. “64 $\check{S}_{\mathfrak{i}}$ atsiminimų faktą patvirtina ir archyviniai dokumentai. Išlaidų knygoje yra ịrašas, kad buvo sumokèta $30 \mathrm{Rb}$ Edmundui Smulskiui už nutaškymą knygnešių paminklo kalkėmis ir cementu ${ }^{65}$. Sąskaita apmokèta jau kitos okupacijos dienomis, $1941 \mathrm{~m}$. liepos $26 \mathrm{~d}$. Nuèmus lentas buvo baigta tvarkyti „Knygnešiu sienelë“, nes iki sovietų okupacijos nebuvo baigtos auksuoti visų knygnešių pavardžių raidès. $1941 \mathrm{~m}$. liepos $16 \mathrm{~d}$. buvo paauksuotos knygnešių paminklinès lentos paskutinio eiliuoto teksto raidès ${ }^{66} .1941 \mathrm{~m}$. gruodžio $17 \mathrm{~d}$. muziejaus sudaryta komisija (pirmininkas - ats. plk. Kazys Ališauskas, nariai - inžinierius Vladimiras Zubovas ir skyriaus vedèjas ats. mjr. Jonas Valaitis) prièmé naujajame sodelyje (taip buvo vadinama "Knygnešių sienelès" vieta) pastatytus postamentus „Sejjejjas“, „Knygnešys“ ir „Vargo mokykla“.

Vytauto Didžiojo karo muziejus visada buvo svarbių ìvykiu sūkuryje. Prasidejjus $1941 \mathrm{~m}$. Birželio sukilimui, pirmąją jo dieną, birželio 23-iąją, 12 val., kai per Kauno radiją sukilèliu vadas Leonas Prapuolenis paskelbė, kad atkuriama Nepriklausomos Lietuvos valstybè ir sudaroma Lietuvos laikinoji vyriausybè, vèl suskambo Laisvès varpas, Lietuvos himnas ir Kovų varpų muzika. Tai padare Karo muziejaus darbuotojai, karo invalidai Bronius Tvarkūnas ir Juozas Petraitis. Jie ne tik susitare su Petru Babicku dèl Laisvès varpo skambesio transliacijos per Kauno radiją, bet ir ant muziejaus pastato ir bokšto iškèle tautinę ir valstybès vèliavas.

Tačiau jau pirmosiomis naujųų okupantų šeimininkavimo Kaune dienomis muziejus patyrè nuostolių. Birželio mèn. Kaune buvo sustojęs i Sovietų Sąungą žygiuojantis generolo feldmaršalo Ernsto Buscho vadovaujamos armijos štabas. Keli šio štabo karininkai atvyko ị muziejų ir no-

\footnotetext{
${ }^{64}$ Raštikis S. Iš generolo Vlado Nagevičiaus veiklos, Vladas Nagius Nagevičius, p. 190191.

${ }^{65}$ İrašas apie sąskaitos apmokẻjimą Smulskiui Edmundui, Kariškai istorinio muziejaus einamujų sq̨skaitų knyga 1941-1942 m., 1. 20.

66 Ten pat.
} 
rejo išrinkti dovaną gimtadienio proga savo vadui. Ats. div. gen. S. Raštikis savo atsiminimuose rašè: „Jie, matyti, gerai pažino senovès ginklus, nes išsirinko iš Muziejaus ginklų kolekcijos geriausią viduramžių riterių kardą (kalaviją - A. J.) ir pareikalavo, kad Muziejus ji dovanotų jų generolui." Toks reikalavimas buvo lygus ịsakymui, ir kardas buvo išneš$\operatorname{tas}^{67}$. Muziejus neteko vieno brangaus eksponato, bet ir vèliau buvo tokių reikalavimų. Tik muziejaus administracija jau buvo drąsesnè ir pradejo priešintis tokiems naujųjų okupantų igeidžiams.

Vokiečių okupacinė valdžia, pradėdama kurtis Kaune, ieškojo patalpų savo įstaigoms, tad pats generalinis komisaras Teodoras Adrianas von Rentelnas apsilankė muziejuje ir pradejo planuoti, kaip čia galètu isitaisyti. Nuogąstaudami dèl tokių ketinimų, ats. brg. gen. V. Nagevičius ir Laikinosios vyriausybès krašto apsaugos ministras ats. div. gen. S. Raštikis susirūpino, kad muziejaus patalpos nebūtų užimtos. Neaišku, kodèl sprendimas buvo pakeistas ir vokiečių administracija įsikūrè Lietuvos užsienio reikalų ministerijos ir Žemès banko rūmuose Vienybės aikšteje. Tai buvo pirmas ir paskutinis kartas, kai generalinis komisaras lankèsi muziejuje.

$1941 \mathrm{~m}$. liepos $10 \mathrm{~d}$. buvo pakeista ir muziejaus vadovybè. Tos dienos švietimo ministro rašte Nr. 20 buvo parašyta: „Kariniai istorinio muziejaus direktorių Žekonị Bronislovą nuo $1941 \mathrm{~m}$. liepos $10 \mathrm{~d}$. atleidžiu iš direktoriaus pareigų. Vytauto Didžiojo karo muziejaus viršininku nuo 1941 m. liepos 10 d. skiriu gen. Nagių Vladislovą. "68

Jau liepos $16 \mathrm{~d}$. buvo atgaivintos žuvusiujų pagerbimo apeigos. Karo muziejaus orkestras turejo groti šiam ceremonialui skirtas melodijas, tačiau neturèjo instrumentų - jie Komisarų tarybos sprendimu gegužès 1 d. kartu su muzikantais buvo perduoti Profsąjungų centro valdybai ${ }^{69}$. Muziejaus vadovybè kreipėsi raštu, prašydama priimti visus orkestrantus $\mathfrak{i}$ darbą Karo muziejuje ir mokèti jiems algas. Kapelmeisteriu buvo paskirtas Vladas Gležys, $\mathfrak{i}$ antraeiles kapelmeisterio pareigas - Emerikas Gailevičius. Instrumentai iš Profsąungų centro valdybos į muziejų buvo parvežti liepos $15 \mathrm{~d}$.

67 Raštikis S. Iš generolo Vlado Nagevičiaus veiklos, Vladas Nagius Nagevičius, p. 194.

68 Raštas Švietimo ministerijos Vytauto Didžiojo karo muziejui (nuorašas), LCVA, f. R-423, ap. 1, b. 3, 1. 41 .

69 Raštas Švietimo ministerijai, 194107 12, ten pat, 1. 24. 
1941 m. liepos 26 d. buvo atstatyti Povilo Lukšio ir Antano Juozapavičiaus biustai. Tai padare tas pats P. Baleniūnas, žmogus, kuris juos ir nuemė. Muziejuje prasidejjo sovietų okupaciją demaskuojantys darbai. Bolševikai mokyklose, fabrikuose, ligoninèse buvo pradèję steigti raudonuosius kampelius, todèl ats. brg. gen. V. Nagevičius, norèdamas sarkastiškai pamėgdžioti buvusị okupantą, Karo muziejuje įrenge „Raudonajji kampelį", kuris vèliau išaugo i̇ Raudonojo teroro skyrių. Švietimo generalinis tarejjas K. Germantas rugsèjo $1 \mathrm{~d}$. paskyrè į Raudonojo teroro skyriaus vedèjo pareigas Joną Vèželị (mokejo III kategorijos atlyginimą, kaip salių prižiūrètojui). Buvo numatyta ịkurti Raudonojo teroro muziejų. Aukštojo mokslo departamentas $1941 \mathrm{~m}$. rugsèjo $20 \mathrm{~d}$. raštu pranešè muziejaus viršininkui, kad generalinis tarejas nutare Raudonajam teroro muziejui suteikti autonominio vieneto teises ir paversti ji Karo muziejumi. Jo vedejju buvo paskirtas Aleksandras Merkelis ir priimti du muziejininkai - Janina Steklickaitè ir Leonas Gabè ${ }^{70}$. Mašininkès pareigas èjo Apolonija Gajauskaitè.

Muziejuje tuo metu buvo šie skyriai: Priešistorinis, Lietuvos Didžiosios Kunigaikštystès, 1914 m., Nepriklausomybès laikų ir - pats naujausias - Raudonojo teroro, padalytas ị dvi dalis. Pirmoje buvo vaizduojama, kaip per spaudą, radiją, mitingus, naudodami plakatus, bolševikai žadèjo Lietuvos gyventojams pasirūpinti jais senatveje, sukurti ramų, šviesų gyvenimą darbininkams, užtikrinti ekonominị ir kultūrinị Lietuvos klestèjimą. Kitoje dalyje palyginimui buvo rodoma, ką per vienus metus bolševikai „nuveiké“: tai - kalèjimai, prigrūsti žmonių, daug nužudytų ūkininkų, moksleivių, darbininkų Pravieniškèse, Rainiuose, Panevėžyje, Zarasuose, ištremtų i Sibirą. Viena dalis buvo skirta Raudonajai armijai: rodoma, kaip 20 šarvuotų Raudonosios armijos divizijų okupuoja Lietuvą ir kaip po metų ta nenugalimoji armija bėga iš Lietuvos, palikdama sužeistus ir sergančius karius, tankus, techniką, vežimus, prikrautus armijos turto, ir kt. Šiame skyriuje buvo ir kampelis 29-ojo teritorinio šaulių korpuso, ị kurị buvo suvaryti likę Lietuvos kariuomenès kariai ir taip baigta likviduoti Lietuvos kariuomene, istorijai parodyti. Vèliau Raudonojo teroro muziejus atsiskyrè ir ịsikūré Laisvès al. 41-11. Muziejus glaudžiai bendradarbiavo su Studijų biuru. Vytauto Didžiojo karo muzie-

\footnotetext{
70 Aukštojo mokslo departamento raštas Vytauto Didžiojo karo muziejaus viršininkui, 1941 m. rugsèjo 20 d., Nr. 21971, LCVA, f. R-423, ap. 1, b. 3, 1. 55.
} 
jus perdavè Raudonojo teroro muziejui turimus eksponatus, likusius po sovietų okupacijos. $1941 \mathrm{~m}$. gruodžio $18 \mathrm{~d}$. Raudonojo teroro muziejaus etatai buvo išbraukti iš Karo muziejaus etatų sąrašo, paliktos patalpos, pasiimtas visas turtas ${ }^{71}$. Pirmoji didelè Raudonojo teroro muziejaus paroda buvo surengta Vytauto Didžiojo kultūros muziejuje 1942 m., vèliau - Vilniuje ir Telšiuose. Turèta planų net vežti ekspoziciją i užsienį (1943 m.).

Vos spejjęs išvalyti muziejų nuo sovietinès propagandos eksponatų, ats. brg. gen. V. Nagevičius susidūrè su naujųjų okupantų reikalavimais, kurie nedaug skyrèsi nuo buvusiųjų. Pirmiausia įsakyta nuo „Laisvès“ paminklo pjedestalo nuimti užrašus „Klaipeda 1923“ ir „Radviliškis 1919“, skirtus Klaipedos sukilimui ir kovoms su bermontininkais, iš sodelio pašalinti Mažosios Lietuvos patriarcho Martyno Jankaus bronzinį biustą. Pertvarkos vyko ir muziejaus Didžiojoje saleje, kur buvo įrengtos Lietuvos kariuomenès pulkų ekspozicijos. Vadovybei buvo ịsakyta išimti visas nuotraukas, trofėjus, susijusius su kryžiuočiais, kalavijuočiais ir bermontininkais. Panaikintas visas skyrius apie lietuvių sukilimą Klaipėdos krašte ir vokiečių nacionalsocialistų bei jų vadų Ernsto Neumanno ir Teodoro von Sasso bylą Lietuvos kariuomenès teisme. Taip pat įsakyta nebegroti Mažosios Lietuvos himno „Lietuviais esame mes gimę, lietuviais turime ir būt" ir pakabinti Adolfo Hitlerio portretą. Šis įsakymas buvo ìvykdytas. Didžiojoje saleje atsiradęs fiurerio portretas buvo papuoštas žalumynais ${ }^{72}$.

Pirmasis generalinis tarëjas Petras Kubiliūnas išsiuntė visoms Švietimo valdybos įstaigoms raštus, kuriuose buvo nurodyta, kokius blankus galima naudoti. Nuo $1941 \mathrm{~m}$. rugpjūčio $26 \mathrm{~d}$. buvo uždrausta rašyti „Lietuvos Respublika“ ir „NN ministerija“, bet leista naudoti Vytit ${ }^{73}$. Spalio 20 d. aplinkraštyje nurodyta, kaip reikia rašyti ir pakabinti ịstaigos pavadinimą: „Istaigų iškabos atskirai vokiečių ir lietuvių kalbomis - kiekviena su Vyčiu. Pirmoji kabinama kairèje durų pusėje, antroji - dešinèje."

71 Raštas apie Raudonojo teroro muziejaus etatų išbraukimą iš Karo muziejaus etatų sąrašo, 1941 m. gruodžio 18 d., LCVA, f. R-423, ap. 1, b. 3, 1. 7.

72 Tekstas apie Vytauto Didžiojo karo muziejų, skaitytas per radiją 1942 m., ten pat, b. 23, 1. 7 .

73 Pirmojo generalinio tarèjo raštas Švietimo valdybai, $1941 \mathrm{~m}$. rugsèjo 10 d., ten pat, b. 1, 1. 5 .

74 Pirmojo generalinio tarèjo raštas švietimo generaliniam tarejjui, $1941 \mathrm{~m}$. spalio $20 \mathrm{~d}$., ten pat, l. 18 . 
Raštuose taip pat nurodyta, kurioje garbingoje vietoje pakabinti „tinkamai aptaisytą Adolfo Hitlerio paveikslą ${ }^{\text {"75 }}$. Švietimo valdyba raštu pranešè muziejaus direktoriui, kad generalinis komisaras 1942 m. rugpjūčio $21 \mathrm{~d}$. rašte parašè: „Generalinès srities muziejuose iki šiol randasi tik parašai lietuvių kalba. Prašau ịsakyti muziejaus vedẻjams visuose muziejuose pirmoje vietoje papildomai padèti vokiškus parašus. ${ }^{\text {"76 }}$ Taip pat privaloma tvarka reikalauta visur vartoti vokiečiu kalbą. Kuriamoms naujoms ekspozicijoms 1942-1943 m. įsigyta nemažai paveikslų, vaizduojančių sovietų okupacijos metus, naujụjų okupantų pergalingus žygius ir jų vadus.

Tokiomis sunkiomis sąlygomis muziejaus viršininkas, norèdamas išsaugoti muziejų, kad jis nebūtų uždarytas, turejo daryti mažus kompromisus, nes, matyt, tai buvo malum necessarium („neišvengiama blogybë“). Jis elgèsi atsargiai, kad nebūtų ižeisti lietuvių tautiniai jausmai ir būtų sušvelnintas vokiečių civilinès valdžios priešiškumas Karo muziejui. Vokiečių administracija ne kartą svarsté, kaip panaikinti ši muziejų, ir apgailestavo, kad tai nebuvo padaryta pirmosiomis okupacijos dienomis, kai lietuviams net buvo leista bolševikų išniekintą Vytauto Didžiojo karo muziejų vèl restauruoti. Vokiečių okupacinè valdžia (generalinis komisaras, jo pavaduotojai, „gebietskomisarai“ (Gebietskommissar) ir kiti nacionalsocialistu partijos nariai, aukšti pareigūnai) boikotavo muziejaus veiklą ir jame nesilankè. Tačiau vokiečių karo komendantas (Oberfeldkommandant) gen. mjr. Emillis Justas ir kiti vokiečiai karininkai, taip pat kareiviai lankydavosi. Tam ịtakos turèjo ir ats. brg. gen. V. Nagevičiaus pažintis su gen. mjr. E. Justu. Šis karininkas ilgus metus buvo Vokietijos karo atašè Lietuvoje ir bendravo su muziejaus vadovybe. $1942 \mathrm{~m}$. spalio 2 d. muziejaus viršininkas pasveikino E. Justą generolo laipsnio suteikimo $\operatorname{proga}^{77}$, o $1943 \mathrm{~m}$. dailininko Jono Mackevičiaus papraše nutapyti jo portretą (šis portretas muziejuje yra ir dabar).

$1942 \mathrm{~m}$. kovo $10 \mathrm{~d}$. laikraščio „„ laisvę “ pirmajame puslapyje buvo paskelbtas Reicho komisaro Rytų kraštui Lohsės atsišaukimas ị gyventojus

\footnotetext{
75 Pirmojo generalinio tarejo raštas švietimo generaliniam tarejjui, $1941 \mathrm{~m}$. spalio $22 \mathrm{~d}$., ten pat.

76 Švietimo valdybos Mokslo ir meno departamento raštas, 1942 m. rugsejjo 1 d., ten pat, b. $6,1.18$.

77 Raštas Lietuvos srities saugumo komendantui ponui generolui Justui, 1942 m. spalio 2 d., LCVA, f. R-423, b. 24, 1. 4.
} 
„Metalo rinkimo akcija Rytų krašte“. Jame primenama, kad vokiečių kariuomenè išvadavo Lietuvą nuo bolševizmo ir pavasarị numatoma didele karinè kampanija. Ši akcija skaudžiai palietè Karo muziejų, todèl galime teigti, kad 1942 m. jam buvo patys sunkiausi. Muziejus neteko keleto svarbių ir brangių Lietuvai eksponatų.

Generalinio komisariato pareigūnai Luethas, Stadennas, von Recke ir kiti uoliai rinko žinias, ką galima būtų paimti iš muziejaus. Jie teiravosi, ką muziejus pasiruošęs atiduoti, bet, negavę atsakymo, kelis kartus pabrèžtinai nurodè, kad pirmiausia turètų būti atiduota ị spalvotųjų metalų laužą statula „Laisve““. Vèliau domètasi muziejaus bokšte buvusiais varpais. Net atsargiai užsiminta ir apie Laisvès varpą. Vyko derybos. Susitarta varpų klausimą atidèti vèlesniam laikui. Tačiau tai nepanaikino sprendimo ir pretenzijų i kitus varinius muziejaus eksponatus. Jiems peržiūrèti buvo sudaryta komisija, o jos vadovu paskirtas Zivilverwaltung politinio skyriaus viršininkas Luethas. Komisija apžiūrejo sodelyje stovinčius biustus, artilerijos pabūklus ir muziejaus eksponatus. Pareikalauta šių daiktų: „Laisvès“ statulos, visų paminklinių biustų, „Knygnešio“, „Riterio“, „Sejjejo“, „Vargo mokyklos“ skulptūrų. Nepamiršo ir didžiojo bokšto laikrodžio varpo. Ats. brg. gen. V. Nagevičius paprašè valdžios raštiško isakymo. Pasiteisino, kad neturès darbininkų šiems darbams atlikti. Jam buvo atsakyta, kad vokiečiai negali duoti darbininkų, nes metalų rinkimas yra laisvas aukojimas Vokietijos karo pramonei, todèl lietuviai turi patys savo jègomis ir savanoriškai šiuos paminklus nuimti ir paaukoti.

Per metalo rinkimo vajų buvo paaukoti šie eksponatai: Petro Rimšos „Vargo mokykla“, Napoleono patranka, poeto Stanislovo Dagilio biustas, Juozo Mikèno „Riterio“ skulptūra iš bokšto, Lietuvos aviacijos prizai, didelè žalvarinė lenta iš Aviacijos skyriaus „Mirštąs lakūnas“ ir daug kitu smulkių daiktų. Muziejaus viršininkas stengèsi, kad ateities kartoms liktų bent tų sunaikinti atiduotų daiktų kopijos ir būtų galima juos iš naujo nulieti. Todèl buvo padarytos gipsinès tų eksponatų kopijos. Tam tikslui muziejus 1942 m. rugpjūčio 27 d. už 658 RM iš bendrovès „Palemonas“ ìsigijo $1050 \mathrm{~kg}$ gipso ${ }^{78}$. Karo muziejus metalo rinkimo akcijai paaukojo

\footnotetext{
78 Irašas apie pervestus pinigus bendrovei „Parama“, 194208 27, ten pat, ịrašo eilès nr. 157.
} 
apie $2100 \mathrm{~kg}$ metalo ${ }^{79}$.

Apie metalo rinkimo akcijos ịvykdymą paskelbe ir laikraštis „I laisvę“. 1942 m. birželio 15 d. straipsnyje „Pavyzdinga Kauno muziejaus vadovybès laikysena“ buvo giriamas Karo muziejaus viršininkas, „kad rinkimo akciją pravedant iš jos iš anksto buvo išskirti meninès, istorinès ir politinès vertès objektai. Tatai ypač liečia Kauno karo muziejaus eksponatus. Nežiūrint $\mathfrak{i}$ tai, Karo muziejaus viršininkas padèkos vertu būdu atidavè keletą muziejinių dalykų. Vienos patrankos vamzdis, muziejaus bokšto riteris, misinginè lenta, sudaužytas biustas, keletas sporto dovanų ir dar keletas biustų buvo paaukoti kaip savotiškas visos lietuvių tautos innašas ị svarbų žaliavos rinkimą kovai prieš bolševizmą. Visi kiti biustai, „Laisvès" paminklas, „Knygnešys“, „Sejjejjas“ ir „Laisvès varpas“ kartu su daugybe dalykų, aišku, nepaliesti. Minètoji auka kompetentinguose organuose sukèlè kaip tik didžiausią susidomèjimą " ${ }^{\text {"80 }}$.

Pirmasis viešas renginys muziejaus sodelyje po nacių okupacijos įvyko 1941 m. rugpjūčio 5 d., kai Laikinoji vyriausybè susirinko ị paskutini posèdį. Apžvelgusi savo šešių savaičių darbą, ji konstatavo: Vyriausybei buvo patikèta ginti Lietuvos suverenumą; per tas šešias savaites ji darè viską, kas galima, kad padètų atkurti kraštą, bet nuo pat pradžių vokiečiai buvo priešiški Lietuvos suverenumui, o vèliau pradèjo kurti ịvairias kliūtis, kurstyti prieš Laikinąą vyriausybę tam tikras politines grupes ir avantiūristus, spręsti savavališkai kai kurių Lietuvos valstybės mažumų klausimą, nesuderinę su lietuvių tautos tradicijomis ir įsitikinimais; pagaliau vokiečių civilinės valdžios ịvedimas ir generalinio komisaro pareiškimas, kad Laikinosios vyriausybės darbas esąs baigtas, padare fiziškai neįmanomą tolesnę Laikinosios vyriausybès veiklą. Dèl to Vyriausybè konstatavo, kad jos veikla yra sustabdoma prieš jos ir lietuvių tautos valią.

Tą pačią dieną per vakarines vèliavų nuleidimo ir pagerbimo apeigas Karo muziejuje Laikinosios vyriausybès atstovai padejjo vainiką prie Nežinomo kareivio kapo ir paminklo „Žuvusiems už Lietuvos laisvę“. Ten jau buvo susirinkusi didelè minia kauniečių, kurie žinojo apie Laikinosios vyriausybès darbo nutraukimą. Tai buvo pirmasis viešas prieš vokiečius

\footnotetext{
79 Raštas švietimo generaliniam tarejui, $1942 \mathrm{~m}$. balandžio 21 d., LCVA, f. R-423, b. 17, 1. 30 .

${ }^{80}$ Padèka metalo aukotojams. Pavyzdinga Kauno Muziejaus vadovybès laikysena, $t$ laisvę, 1942 m. gegužès 15 d., nr. 113.
} 
nukreiptas renginys. Dẻl šio renginio nemalonumų turejjo Karo muziejaus viršininkas, bet griežtesnių priemonių nebuvo imtasi. Kaip prisimena ats. div. gen. S. Raštikis, gestapo tardymo ats. brg. gen. V. Nagevičius sulaukè tų metų rugsèjo mènesị, kai su kitais Aktyvistų fronto vadovybès nariais pasirašè memorandumą vokiečių civilinei valdžiai. Jame švelnia forma buvo nurodoma, ką blogo padarè vokiečių civilinè valdžia lietuvių tautai per tuos kelis okupacijos mènesius ${ }^{81}$.

Dar didesnè demonstracija Karo muziejaus sodelyje įvyko per 1942 m. Vèlines. Tą dieną i vakarinę vèliavų nuleidimo ceremoniją susirinko didžiulè minia žmonių. Dalis būriavosi šalia esančiose gatvėse. Prie Nežinomo kareivio kapo buvo padèta 50 vainikų ir daugybè gèlių. Oficialioji dalis praejo ramiai, bet vèliau susirinkusi minia èmè dainuoti patriotines dainas, pasigirdo nedraugiškų šūkių, nukreiptų prieš vokiečius. Dèl šio incidento ị nemalonę pateko muziejaus viršininkas ats. brg. gen. V. Nagevičius. Jam grèsè suėmimas, bet byla baigèsi tuo, kad buvo nubaustas pinigine bauda. Tačiau šis įvykis turèjo tiesioginių padarinių ateičiai. Buvo uždraustos bet kokios iškilmès prie Nežinomo kareivio kapo ir groti himną Karo muziejuje. Norint atlikti Lietuvos himną, reikejo gauti generalinio komisaro leidimą ${ }^{82}$. Nukentèjo ir tose Vèlinèse grojęs karinis orkestras, vadovaujamas Florijono Valeikos. Jis buvo laikinai išformuotas. Daugiau tokių incidentų Karo muziejaus sodelyje nebuvo, todèl visus likusius okupacijos metus Vèlinès visada ir toliau jame buvo minimos. Paskutinis toks minejjimas įvyko $1943 \mathrm{~m}$. lapkričio 2 d. Jame dalyvavo ir vainikus prie Nežinomo kareivio kapo ir paminklo „Žuvusiems už Lietuvos laisvę“ padejo Kauno miesto burmistras, Visuomenès reikalų departamento, Sveikstančiųjų karių kuopos, savivaldos įmonių atstovai, gimnazijų mokiniai ir ịstaigų darbuotojai ${ }^{83}$. Per ceremoniją grojo Karo invalidų orkestras, buvo sugiedota „Marija, Marija“ ir Tautos himnas.

1942 m. birželio 22-ąją pradèta minèti Sovietų Rusijos ir Vokietijos karo pradžios, dar vadinama išsilaisvinimo iš bolševikų, diena. Ji buvo švenčiama visoje Lietuvoje, ypač iškilmingai trejus metus - Kaune. Tais

\footnotetext{
81 Vladas Nagius Nagevičius, p. 201.

82 Raštas vidaus reikalų generaliniam tarejjui, 1942 m. lapkričio 20 d., LCVA, f. R-423, b. $29,1.57$.

${ }^{83}$ Vèlinių proga buvo padèti vainikai ant Nežinomo kareivio kapo, Ateitis, $1944 \mathrm{~m}$. lapkričio 3 d., nr. 255, p. 5.
} 
sunkiais karo metais pradèta minèti ir dar viena skaudi Lietuvai data $1941 \mathrm{~m}$. birželio 14-oji, pirmųjų trèmimų metinès. $1943 \mathrm{~m}$. birželio $14 \mathrm{~d}$. buvo minima Tautos gedulo diena. Visoje Lietuvoje laikytos gedulingos mišios už bolševikų nukankintus ir ištremtus Lietuvos žmones. Kaune, Karo muziejaus sodelyje, gausi kauniečių minia susirinko paminèti žudynių ir tremties aukų. Kalbejjo Vidaus reikalų departamento direktorius, komiteto pirmininkas Krikščiūnas, pirmąji generalinį tarèją pavaduojantis susisiekimo technikos tarejjas inž. Kazys Germanas, Savitarpio pagalbos vykdomojo komiteto pirmininkas prof. Ignas Končius. Per iškilmes grojo Policijos pučiamųų orkestras, vadovaujamas Zenono Jonušo, dainavo Vinco Kudirkos choras, vadovaujamas prof. N. Martinonio ${ }^{84}$. Gedulo minejjimas baigèsi Vokietijos ir Lietuvos himnais ir vainikų padejimu prie Nežinomo kareivio kapo. Ištremtieji buvo pagerbti ir 1944 m. birželio 13 d. Pirmasis generalinis tarèjas P. Kubiliūnas per radiją pasakè kalbą ir kartus su kitais savivaldos pareigūnais padejjo vainiką prie Nežinomo kareivio kapo ${ }^{85}$.

1943 m. liepos 17 d. sukako 10 metų nuo S. Dariaus ir S. Girèno žūties Soldino miške. Šis įvykis buvo paminètas, tik ne taip iškilmingai, kaip nusipelnè. Apie tai laikraštyje „Ateitis“ rašyta: „Šiemet liepos $17 \mathrm{~d}$. Darius ir Girenas buvo pagerbti kukliai, taip, kaip diktuoja karo meto sąlygos. "86 Tą dieną per vèliavos nuleidimo ceremoniją buvo paminèta ši skaudi data ir prie Nežinomo kareivio kapo. Susirinkusi tūkstantinè žmonių minia susikaupusi prisiminè lakūnų žygdarbi ir išklause Karo invalidų pučiamųjų orkestro atliekamus Lietuvos ir Vokietijos himnus, sugiedojo „Marija, Marija“. Ivairių organizacijų atstovai, sportininkai ir visuomenininkai padejo gèlių ant Nežinomo kareivio kapo ir, išklausę S. Dariaus ir S. Girèno testamentą, išsiskirste் ${ }^{87}$. Tą dieną buvo padèti 29 vainikai ir 15 gèlių puokščių ${ }^{88}$.

84 Tautos gedulo dienos - birželio 14 d. - minèjimas Kaune, Ateitis, 1943 m. birželio 15 d., nr. 136.

85 Ištremtuosius prisimenant, Ateitis, 1944 m. birželio 15 d., nr. 138.

86 Dariaus ir Girèno paminèjimas Karo muziejaus sodelyje, Ateitis, 1943 m. liepos 17 d., nr. 164 , p. 4.

87 Ten pat.

88 Minint Atlanto nugalètojų Dariaus ir Girèno 10 metų mirties sukaktį, LCVA, f. R-423, b. $44,1.67$. 
Susipažinus su renginiais, kurie vyko Karo muziejaus sodelyje nacių okupacijos metais, natūraliai turètų kilti klausimas: ar buvo minima Vasario 16-oji? Lietuvos nepriklausomybès diena oficialiai nebuvo minima. Štai koki generalinio komisaro atsakymą gavo pirmasis generalinis tarejjas Petras Kubiliūnas 1943 m. sausio 27 d.: „Pagal man duotus Reicho komisaro Rytų kraštui nurodymus pranešu, kad vasario 16 d. štai kas yra nustatyta: a) Vasario $16 \mathrm{~d}$. yra darbo diena; b) vietos savivalda nedaro jokių iškilmių; c) mokyklose tą dieną dirbama, bažnytinès iškilmès šios dienos proga neleistinos; d) minejjimai uždarytose patalpose, eisenos ir demonstracijos aikštėse neleidžiamos; e) vèliavų iškèlimas bus tylomis pakenčiamas. <..>> Nieko prieš neturime, jei tamsta su kitais generaliniais tarèjais be kurio nors skelbimo vasario $16 \mathrm{~d}$. priešpiet padèsite vainiką. Koncertas ar prakalba per radiją nebus leidžiama." ${ }^{\text {"9 }}$

Šiame rašte, išsiųstame ị ịvairias ịstaigas, buvo P. Kubiliūno prierašas, jog policija bus informuota, kad netrukdytų ịstaigoms ir gyventojams iškelti lietuvių ir vokiečių vèliavų. Vasario 16-oji tais metais buvo paminèta taip, kaip liepè nacių okupacinè valdžia, o prie Nežinomo kareivio kapo padèti 56 vainikai $^{90}$. Juos padejo visi generaliniai tarèjai, Kauno burmistras, Žemès tvarkymo departamento, Miškų generalinès direkcijos, VDU studentų atstovybės, Kauno konservatorijos studentų, Lietuvos advokatūros, Kainų direkcijos, daugelio gimnazijų, ịstaigų ir organizacijų atstovai. Dedant vainikus grojo Karo muziejaus orkestras.

Nors vokiečių civilinė ir karinè administracija kūrẻ naujas tradicijas, muziejaus vadovybè ypač stengèsi tęsti buvusias. Be vèliavos pakèlimo ir nuleidimo ceremonijos, tyliai minimos Vasario 16-osios, muziejuje buvo išsaugota ir dar viena tradicija - Vytauto Didžiojo kapeloje šarvoti Lietuvai nusipelniusius asmenis. Kad būtų galima ją tęsti, dèl leidimo reikèjo susirašinèti su civilinès valdžios atstovais, pirmuoju generaliniu tarèju. Be pirmojo generalinio tarejjo sutikimo kiekvienu atveju šarvoti muziejuje nebuvo galima. Muziejaus viršininkas turèjo parengti taisykles, kas ir už kokius nuopelnus gali būti jame šarvojamas. Taisyklių pirmajame punkte parašyta: „Mirusiųjų kūnų viešas pagerbimas ir pašarvojimas Vytauto Didžiojo karo muziejuje gali būti atliekamas tik tais atvejais, jei

${ }^{89}$ Generalinio komisaro raštas pirmajam generaliniam tarẻjui P. Kubiliūnui, $1943 \mathrm{~m}$. sausio 27 d., ten pat, b. 44, 1. 6 .

90 Ten pat, 1. 7. 
velionis ypač daug ir garbingai pasitarnavęs visai lietuvių tautai ir tikrai užsitarnavęs visos tautos pagarbą ir dèkingumą. ${ }^{\text {"91 }}$

Pirmasis nacių okupacijos metais, $1942 \mathrm{~m}$. vasario 6 d., kapeloje buvo pašarvotas tarpukario Lietuvos kariuomenès dim. gen. Jonas Jurgis Bulota (1855-1942), žmogus, visą savo gyvenimą atidavęs Lietuvos kūrimui, varpininkas, knygnešys, pirmosios sporto organizacijos „Lietuvos sporto lyga" steigejjas, Lietuvos universiteto Veterinarijos skyriaus docentas, Lietuvos kariuomenès kūrèjų savanorių sajungos garbès narys ir kt. Karstas buvo pridengtas trispalve. Aplink ji buvo pastatyti vainikai nuo generalinio komisaro dr. T. A. von. Rentelno, pirmojo generalinio tarèjo ats. brg. gen. P. Kubiliūno, veterinarijos dr. Knobbès, Vyr. savitarpinès pagalbos draugijos, Karo muziejaus, Vokietijos kariuomenès komendanto Lietuvoje gen. Emilio Justo, Lietuvos karo invalidų, Veterinarijos akademijos profesorių ir studentų, Kauno aukštųjų mokyklu studentų. Prieš išlydint žodị tarè ats. brg. gen. V. Nagevičius. Uždengtą karstą Lietuvos kariuomenès karininkai nunešè prie Nežinomo kareivio kapo - dim. gen. J. Bulota paskutini kartą dalyvavo vèliavos nuleidimo ceremonijoje ${ }^{92}$.

Po keturių mėnesių Vytauto Didžiojo muziejaus kapeloje vèl vyko atsisveikinimas su išskirtine asmenybe $-1942 \mathrm{~m}$. birželio $1 \mathrm{~d}$. mirusiu Jonu Vileišiu. Šioms laidotuvėms buvo sudaryta laidojimo komisija (pirmininkas - Kauno miesto burmistras Stasys Kenstavičius, nariai: ats. brg. gen. gen. V. Nagevičius, viceburmistras Jonas Pikčilingis, teisingumo generalinis tarèjas Mečislovas Mackevičius, Felicija Bortkevičiené, advokatas Zigmas Toliušis, dailininkas Antanas Žmuidzinavičius, advokatas J. Nemeikša, savivaldybės darbuotojai - juriskonsultas advokatas Eduardas Sudikas ir Ūkio skyriaus vedèjas Justas Valys ${ }^{93} .1943 \mathrm{~m}$. dar du Lietuvai nusipelnę asmenys buvo pašarvoti muziejuje: balandžio $16 \mathrm{~d}$. karo invalidas, dviejų Vyčio Kryžiu kavalierius Jonas Karutis, o spalio 15 d. - kompozitorius, profesorius Stasys Šimkus. Kompozitoriaus karstas buvo uždengtas trispalve, garbės sargyboje stovejo Kauno Didžiojo teatro artistai, konservatorijos studentai, Karo invalidų orkestro nariai,

\footnotetext{
91 Mirusiųjų pašarvojimo ir pagerbimo taisyklès, LCVA, f. R-423, b. 17, 1. 55.

92 Vakar Kaune palaidotas gen. J. Bulota, I laisvę, 1942 m. vasario 10 d., nr. 34.

93 Mirè Jonas Vileišis, I laisvę, 1942 m. birželio 2 d., nr. 127.
} 
muzikai. Atsisveikinimo kalbas prie atviro karsto pasake Didžiojo teatro direktorius Vladas Ivanauskas, muzikas Konradas Kaveckas, muziejaus viršininkas V. Nagevičius ir kiti ${ }^{4}$. Karstas iš muziejaus buvo išneštas pro Karo invalidų sargybą gaudžiant bokšto varpams.

Paskutiniais antrosios okupacijos mènesiais muziejuje rūpintasi eksponatų apsauga. $1944 \mathrm{~m}$. vasario $5 \mathrm{~d}$. buvo sudaryta komisija S. Dariaus ir S. Gireno eksponatams saugoti nuo galimų bombardavimų. Komisijos pirmininku išrinktas Karo muziejaus ats. plk. ltn. Kazys Ališauskas, nariu - ats. mjr. Jonas Valaitis; kviestiniai nariai buvo ats. mjr. Vytautas Jablonskis, ats. mjr. Jonas Mikėnas, S. Dariaus ir S. Girèno komiteto atstovas Algirdas Tomas Zauka. Susirinkusi komisija apžiūrejjo Dariaus ir Girèno eksponatus ir nusprendè: 1) skrydžio ir laidotuvių nuotraukas, dokumentus, pinigus, laikrodžius, pasus, drabužius, navigacijos įrankius, žemèlapius, lèktuvų „Lituanica I“ ir „Lituanica II“ modelius, Dariaus testamento nuorašą, 2 našlaičių auką paminklui statyti, 2 lèktuvo šonų lentas (nuorašai aukotojų skrydžiui) laikinai paimti iš Karo muziejaus ir padèti ị slèptuvę; 2) vietoje palikti lèktuvo „Lituanica I“ laužą (išnešti negalima, reikètų supjaustyti), skrydžio USA-Europa kelią ir laurų lapus - ąžuolo dažytoje lentoje; 3) slèptuvès klausimo Dariaus ir Girèno daiktams padèti nesvarstyti ${ }^{95}$.

Kitas posėdis dèl eksponatų apsaugos buvo sušauktas balandžio $26 \mathrm{~d}$. Posėdžiavo pirmininkaujantis ats. brg. gen. V. Nagevičius ir dalyviai: ats. div. gen. S. Raštikis, ats. brg. gen. Juozas Barzda-Bradauskas, Kauno priešlèktuvinès apsaugos viršininkas kpt. Vytautas Petruškevičius, Karo muziejaus skyriaus vedejai ats. plk. ltn. K. Ališauskas ir ats. mjr. J. Valaitis, sekretorius Emilis Šneideraitis. Svarstyta, kur paslèpti eksponatus. Pasiūlytos šios vietos: 1. Veterinarijos akademijos Vilijampoleje patalpos po rūmų laiptais $(25 \mathrm{kv} . \mathrm{m})$. 2. Arkivyskupo rūmai - vyskupijos archyvas (18 kv. m). 3. Didelis, bet nesaugus rūsys arkivyskupo ūkyje. 4. Igulos bažnyčia (du kambariukai rūsyje, saugūs visais atvejais). 5. Ginklavimosi laboratorijos patalpos, pritaikytos slèptuvei (saugios visais atžvilgiais) (50 kv. m). 6. Muziejaus patalpos. Viską apsvarsčius nutarta, kad tinka-

\footnotetext{
94 Kompozitorius prof. Stasys Šimkus palydètas amžinojo poilsio vieton, Ateitis, 1943 m. spalio 18 d., nr. 242.

95 Sąrašai eksponatų, supakuotų dèžèse ir paimtų ì slëptuvę apsaugai nuo galimo oro puolimo, 194402 05, VDKM rinkiniai, b. 19, 1. 1.
} 
miausios patalpos yra Ginklavimosi laboratorijoje ir Igulos bažnyčioje. Taip pat buvo dar kartą paprašyta ats. brg. gen. J. Barzdos-Bradausko su specialistais inžinieriais paieškoti pačiame muziejuje tinkamos vietos eksponatams saugoti ${ }^{96}$.

Eksponatams supakuoti už 231 RM buvo ịsigyta 70 dèžių ir už 150 RM 30 m galiono „Pavasario“ knygyne ${ }^{97}$. Pasiruošta ir gaisro gesinimui, jei muziejus būtų padegtas. Iš A. Puskepalaičio už 240 RM nupirkta 20 medinių statinių vandeniui ${ }^{98}$. Šie daiktai buvo išvežti ar ne, duomenų neturime, bet S. Dariaus ir S. Girèno eksponatai visi išliko. Viskas buvo išsaugota. Labai svarbu tai, kad tokiam scenarijui ruošèsi ir muziejaus vadovybè, kuri tai darè labai atsakingai ir profesionaliai. Visų šių priemonių neprireikè, nes muziejus nebuvo bombarduotas. Daug nuostoliu jis patyrè dèl vokiečių susprogdintos elektros stoties, kuri stovèjo šalia muziejaus. Buvo išdaužyti visi muziejaus lubų švieslangiai, igriuvo vidinis stogas, išdužo dauguma langų.

Pirmoji sovietų okupacija truko vienus, nacių - trejus, antroji sovietų okupacija - 56 metus ir neatpažistamai pakeitè muziejų. Abu okupantai elgèsi panašiai, ir tai labai taikliai apibūdino ats. div. gen. S. Raštikis: „[I]r rusai, ir vokiečiai negalèjo pakęsti tokio didelio, reikšmingo ir ịtakingo lietuvių tautos patriotizmo ir kilniausių tautinių jausmų centro ir šaltinio. Abu jie norejo panaikinti karo muziejų. <...> rusų bolševikų ir vokiečių nacionalsocialistų tikslai buvo tie patys, tik metodai skyrèsi. " 99

Antroji sovietų okupacija muziejui buvo labai sunki: jos metu buvo sunaikinta jo veiklos ideja, o jis pats paverstas sovietų propagandos įstaiga. $1944 \mathrm{~m}$. rugsejo $9 \mathrm{~d}$. jis neteko savo pavadinimo ir buvo pavadintas Valstybiniu kariškai-istoriniu muziejumi ${ }^{100}$, o 1956 m. balandžio $13 \mathrm{~d}$. Kauno valstybiniu istorijos muziejumi ${ }^{101}$.

\footnotetext{
96 Ten pat, 1. 7.

97 Ten pat, Išrašas apie išmokètus pinigus už dèžes ir galioną, 19440331.

98 Ten pat, VDKM rinkiniai, b. 19, 1. 7.

99 Vladas Nagius Nagevičius, p. 188.

${ }^{100}$ Vytauto Didžiojo karo muziejaus svarbiausių įvykių kronika, Muziejaus istorinè kronika (1919-1951), Vytauto Didžiojo karo muziejus 2010 metais, almanachas, p. 78.

${ }^{101}$ Muziejaus istorinè kronika (1952-1970), Vytauto Didžiojo karo muziejus 2011 metais, almanachas, p. 207.
} 
Po Antrojo pasaulinio karo muziejus nukentejjo dèl apgriauto pastato: vokiečiams susprogdinus šalia esančią elektrinę, ịkrito jo stogo švieslangiai ir išbyrejjo langai. Per porą metų buvo sutvarkyti šie karo padariniai, tačiau prasidejo dar sudettingesnis ir skausmingesnis laikotarpis, kai buvo naikinami jo rinkiniai. Pirmiausia buvo atlikta jų revizija. Sudaryti sąrašai buržuazinès Lietuvos dokumentų, fotonuotraukų ir daiktų, kuriuos reikalauta perduoti VRM archyvui arba sunaikinti.

1951-ieji Valstybiniam kariškai-istoriniam muziejui buvo didžiųjų netekčių metai. Tais metais iš muziejaus buvo išvežta, sunaikinta arba uždrausta eksponuoti dauguma eksponatų, kurie sudarè pagrindinę tarpukario karybos istorijos kolekciją. Lietuvos SSR Kultūros-švietimo îstaigų komiteto prie LSSR Ministrų Tarybos $1951 \mathrm{~m}$. kovo 20 d. nurodymu Nr. D/612 Vidaus reiklų ministerijos archyvui buvo perduotos 804 fotonuotraukos (116 vinječių ir 688 nuotraukos su dublikatais) ir 55 nuotraukų albumai: Lietuvos kariuomenès (29 vnt.), Šaulių sąungos (13 vnt.), lenkų (13 vnt.), taip pat 27 Lietuvos kariuomenès vèliavos ${ }^{102}$. Kultūros-švietimo ịstaigų komiteto prie Lietuvos SSR Ministrų Tarybos nutarimu Nr. d/611 muziejaus fondai buvo „apvalyti“ nuo 662 neturinčių vertès muziejinių eksponatų, Šaulių sąungos ir kitų organizacijų vèliavų. Muziejaus direktoriaus J. Apuoko-Maksimavičiaus įsakymu Nr. 4 buvo nurodyta, kaip tai reikia atlikti: „Visus Šaulių sąungos ženklus nuo vèliavų nuimti ir sunaikinti, tas vèliavas, nuo kurių ženklai nenusiims, sunaikinti ištisai. Vẻliavų kotų antgalius užpajamuoti kaip metalo laužą. Sunaikintų vèliavų medžiagą, atraižas, tinkančias muziejaus eksponatų apiforminimui - atskirai; kandžių sukapotus, mažai bei netinkančius apiforminimo darbams gabalus bei visą kitą medžiagą i skudurus. " ${ }^{103}$ I LSSR Valstybinès respublikinès bibliotekos spec. fondus buvo perduoti: buržuazinès Lietuvos žemèlapiai ir schemos (51 vnt.), tekstai ir raštiški dokumentai (61 vnt.) ${ }^{104}$. Sunaikinti buvo pasmerktos ir Šaulių sąjungos vèliavos, surinktos muziejuje $1940 \mathrm{~m}$., uždarant sąjungą. Iš viso muziejuje buvo laikomos 645 įvairių Šaulių sąungos būrių vèliavos, tarp jų -

\footnotetext{
${ }^{102}$ Vytauto Didžiojo karo muziejaus svarbiausių ìvykių kronika, Muziejaus istorine kronika (1919-1951), Vytauto Didžiojo karo muziejus 2010 metais, almanachas, p. 87.

103 Ten pat.

104 Ten pat, p. 88.
} 
kelios Lietuvos kariuomenės kūrẻjų savanorių sąjungos ir Lietuvos karo invalidų vyčių brolijos. Nedaugelis Šaulių sąjungos vèliavų buvo išsaugotos muziejuje dirbusių žmonių pastangomis. Lietuvos kariuomenès pulkų vèliavos buvo saugomos Kaune esančiame VRM archyve. Dalį vèliavų iš šio archyvo patalpų išvogè, jas pamatę, susipratę kauniečiai. Likusios buvo išvežtos ị Vilnių ir saugomos KGB patalpose.

Eksponatų paiešką pradèjome muziejaus Sąjūdžio grupès sprendimu, žinodami, kad eksponatai išvežti. Jau 1989 m. gegužès 25 d. direktorius Juozas Jurevičius parašè raštą Nr. 129 dèl paimtų iš muziejaus eksponatų grąžinimo. Dalis Lietuvos kariuomenès vèliavų buvo atgautos anksčiausiai. Jų ieškojau aš pati, o raštus pasirašydavo muziejaus direktorius. Vèliavos iš VRM buvo atneštos ị Centrinị valstybès archyvą ir $1989 \mathrm{~m}$. gruodžio $29 \mathrm{~d}$. aktu perduotos muziejui. Déžèse buvo sukrauta 13 vèliavų, jas traukiniu parsivežiau į Kauną. 1993 m. Lietuvos valstybès centrinis kino-fotoarchyvas grąžino 20 kariuomenès albumų. Šios okupacijos poveikị muziejui dar reikètų išsamiau ištirti. Aptariamoji tema neleidžia šio laikotarpio nagrinèti, nes visos tarpukariu sukurtos tradicijos buvo uždraustos, o ekspozicijos sunaikintos. Muziejus sovietmečiu - atskiro straipsnio tema.

\section{ATGIMIMAS 1988-1991 M. IR DABARTIS}

1988 m. birželio 9 d. muziejuje buvo ịkurta Sąjūdžio grupè, ją sudare 9 žmonès. 1988 m. buvo išmontuota sovietinè ekspozicija. 1988 m. spalio $9 \mathrm{~d}$. virš muziejaus bokšto suplevèsavo trispalvè, kurią iškèlè disidentas Algirdas Patackas ir sajūidietis Kazimieras Uoka. Šiame akte aktyviai dalyvavo ir muziejaus darbuotojai.

Lietuvos kultūros fondo iniciatyva buvo pradèta rūpintis atkurti Karo muziejaus sodeli. Pirmieji paminklai atstatyti $1988 \mathrm{~m}$. rudeni. Pirmiausia buvo atkurti postamentai ir jau Naujụjų metų išvakarèse, gruodžio $30 \mathrm{~d}$., ant jų pastatyti Simono Daukanto, Vinco Kudirkos, Jono Basanavičiaus ir Maironio biustai, rasti ịvairiuose muziejuose ${ }^{105}$. Laisvés paminklo ati-

${ }^{105}$ Gečas S. Panteono atkūrimas, Vytauto Didžiojo karo muziejus 2010 metais, almanachas, p. 203. 
dengimo ceremonija ịvyko 1989 m. vasario 16 d., joje dalyvavo beveik visas muziejaus kolektyvas, merginos ir moterys, pasipuošusios tautiniais drabužiais, stovejjo paminklo papèdèje. Taip buvo pradètas atkurti Karo muziejaus sodelis, dar vadinamas panteonu. Paskui atstatyti Karo muziejuje išsaugoti Martyno Jankaus ir Petro Vileišio biustai. Vlado Putvinskio, Povilo Lukšio, Antano Juozapavičiaus ir Silvestro Žukausko biustai buvo sunaikinti, todèl juos reikejjo atkurti.

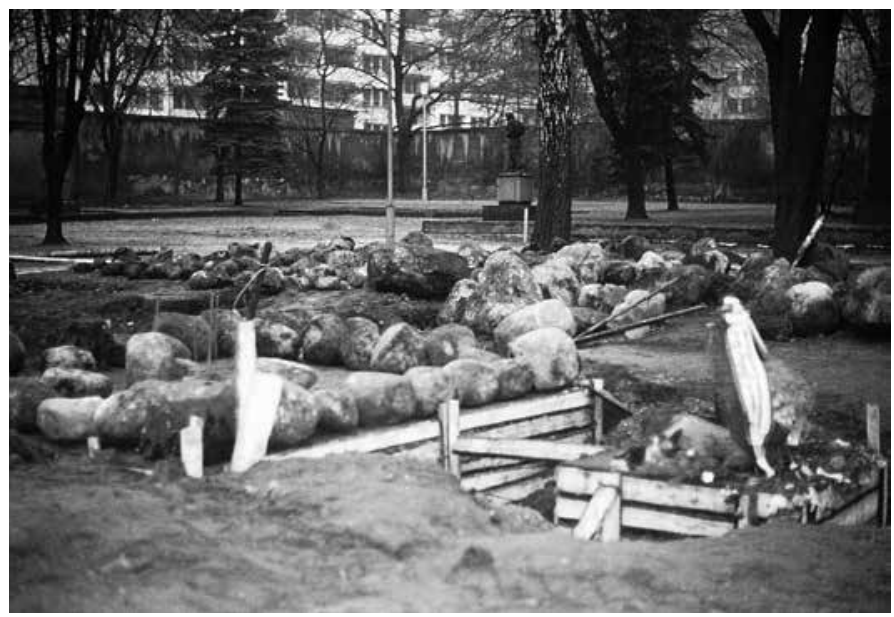

Paminklo

„Žuvusiems

už Lietuvos

laisvę"

atstatymas ir

Kariuomenès

dienos

minèjimas.

$1989 \mathrm{~m}$.

lapkričio

$23 \mathrm{~d}$.

$N-12402 / 16$

Svarbiausias darbas atkuriant sodelį buvo atstatyti paminklą „Žuvusiems už Lietuvos laisvę“. 1989 m. rugsėjo mèn. organizuota 16 asmenų grupè penkiasdešimtyje kautynių dèl nepriklausomybès vietų rinko akmenis. Vienos iš grupių, kuri akmenis rinko Aukštaitijoje, narių buvo muziejaus darbuotojai Arvydas Pociūnas ir Jonas Vytautas Žukas.

Kartu su atgimstančiu sodeliu atgimė ir muziejus. Jo darbuotojai pradejo rengti parodas, kurios muziejuje nebuvo rengiamos nuo $1944 \mathrm{~m}$. Pirmosios atgimimo laikų parodos buvo šios: 1988 m. - „Iš sporto istorijos“ (Arvydas Jakštas ir Algirdas Markūnas), skirta Olimpiados 50-mečiui, I pusmeti - „Lietuva ir ekologija“ (Audronè Žemaitytè-Veilentienè), kilnojamoji paroda „Lietuvos kariuomenè 1918-1940 m.“ (Arvydas Pociūnas ir Jonas Vytautas Žukas). 1989 m. rugpjūčio 23 d., Baltijos kelio dieną, muziejuje buvo atidaryta paroda, skirta Ribentropo-Molotovo pakto pasirašymo 50-mečiui, „1939-1940-1941 m. ìvykiai Lietuvoje“, kurioje 


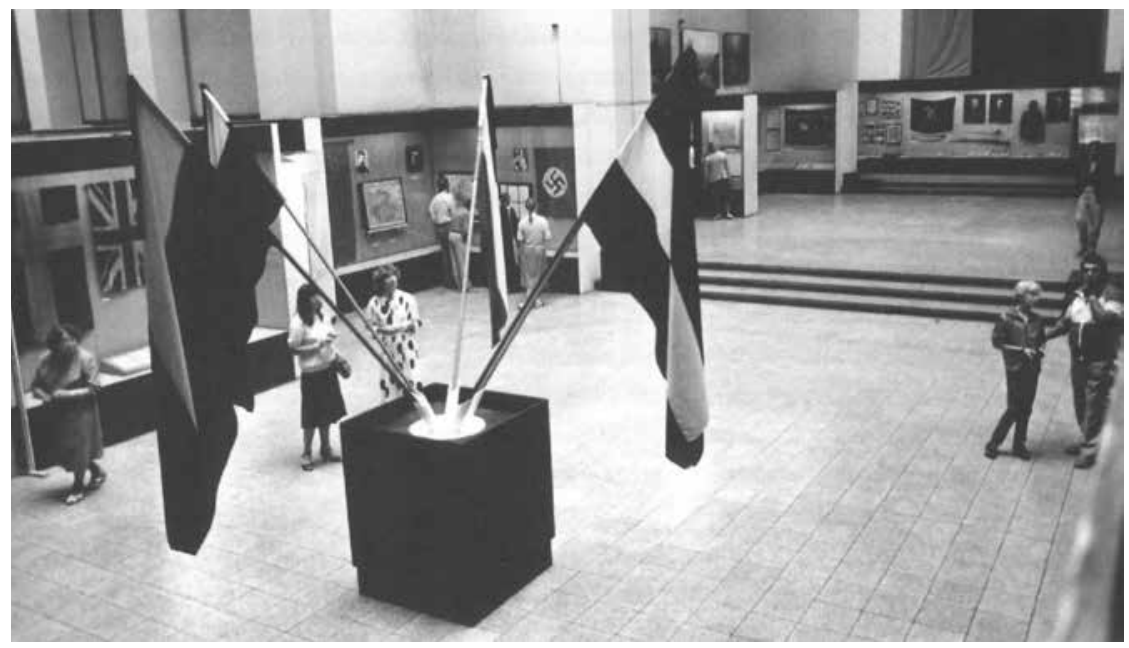

Parodos, skirtos Ribentropo-Molotovo pakto 50-mečiui, atidarymo fragmentas. 1989 m. rugpjūčio $23 \mathrm{~d}$.

dar okupacijos sąlygomis buvo eksponuojamos viena šalia kitos Sovietų Sąungos ir nacistinès Vokietijos vèliavos (autoriai Aušra Jurevičiūtè, Algirdas Markūnas ir Jonas Vytautas Žukas). Po parodos atidarymo visi Sąūdžio grupès nariai vyko ị Baltijos kelią. $1990 \mathrm{~m}$. buvo parengta nauja paroda „Lietuviai tremtyje“, kurioje buvo eksponuojami daiktai, surinkti per 1989-1990 m. ekspedicijas Sibire (autoriai Aušra Jurevičiūtè ir Algirdas Markūnas).

1990 m. sausio 29 d. muziejus susigrąžino Vytauto Didžiojo vardą ir vèl pradejjo vadintis Vytauto Didžiojo karo muziejumi. 1990 m. vasario 16 d. buvo atidaryta paroda „Lietuvos kariuomenè kovose už Lietuvos Nepriklausomybę 1918-1920 m.“" (autoriai Arvydas Pociūnas, Dalè Vosylienè ir Jonas Vytautas Žukas), o praejjus vos porai mėnesių po Kovo 11-osios Akto paskelbimo, gegužès 15 d., - paroda, skirta Steigiamojo Seimo 70-mečiui (autoriai Audronè Žemaitytè-Veilentienė ir Algirdas Markūnas), taip pat paroda Kariuomenès dienai - „Lietuvos kariuomenè daileje“.

1991 m. sausio 8-15 d. 6 Vytauto Didžiojo karo muziejaus darbuotojai - Jonas Daujotas (a. a.), Lucija Murnikaite (a. a.), Algirdas Markūnas, Aušra Jurevičiūtė, Audronè Žemaitytė-Veilentienė ir Rimas Ba- 


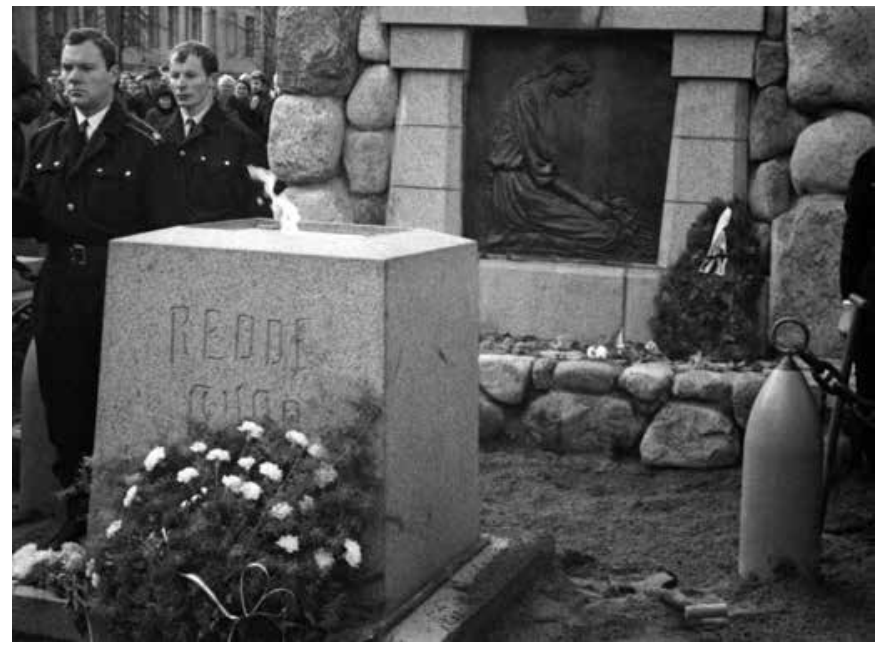

Nežinomo

kareivio

perlaidojimo

iškilmèse

Garbès

sargyboje stovi

tik ką prisiekę

pirmieji laisvos

Lietuvos

savanoriai.

$1990 \mathrm{~m}$.

lapkričio $23 \mathrm{~d}$.

Fa-14887-8

naitis - dalyvavo šalies parlamento gynyboje, o Rūta Balynienè budejo Sitkūnuose, Kauno rajone. Už tai Algirdas Markūnas, Aušra Jurevičiūtè ir Audronė Žemaitytė-Veilentienè buvo apdovanoti Sausio 13-osios atminimo medaliais. Tęsiant tradiciją muziejuje šarvoti Lietuvai nusipelniusius asmenis, $1991 \mathrm{~m}$. sausio $15 \mathrm{~d}$. jo Didžioje saleje buvo pašarvotas prie Vilniaus televizijos bokšto žuvęs kaunietis Titas Masiulis. Šiose laidotuvèse dalyvavo ir muziejaus darbuotojai, dvi dienas ir naktis budeję jo patalpose.

1991 m. muziejaus darbuotojai toliau tęsé muziejaus grąžinimo ì objektyvios istorijos propagavimo véžes darbus. Buvo rengiamos parodos, atspindinčios to meto aktualijas ir karybos istoriją. Daugybė parodụ buvo surengta Lietuvos kariuomenės karininkų jubiliejų proga, aktyviai atkuriama tradicija paminèti tuos, kurie kovojo dèl Lietuvos laisvès. Muziejaus darbuotojai glaudžiai bendradarbiavo su dar likusiais gyvais tarpukario Lietuvos karininkais, puskarininkiais ir kareiviais, jų šeimų nariais. 1996 m. Naujausių laikų karybos skyriaus darbuotojai iššifravo Laptevų jūros tremtinès Dalios Grinkevičiūtės 300 lapų rankraštị, kartu parengè spaudai kriptonimų ir tekste minimų pavardžių sąrašą. Knygą išleido Lapteviečių draugija.

Muziejaus darbuotojai buvo ne tik senųjų tradicijų gaivinimo iniciatoriai, bet ir naujų kūrèjai. Taip 1989 m. prie Vytauto Didžiojo karo 
muziejaus Arvydo Pociūno ir Jono Vaičenonio iniciatyva ir pastangomis buvo ¡kurtas Kauno karo istorijos klubas. Klubo tikslas buvo siejamas su svajone atkurti Lietuvos kariuomenę. Pirmas oficialus renginys buvo 1992 m. Napoleono persikèlimo per Nemuną inscenizacija.

Karo muziejaus istorikai ir Šaulių sąjungos vadovybė nusprendė atgaivinti vèliavos pakèlimo ceremoniją ir tuo tikslu kreipėsi į Šaulių sąjungos narius, tarp kurių buvo partizanų, tarpukario Lietuvos kariuomenès karininkų ir tremtinių. Šauliai palaikè iniciatyvą - mokèsi žygiuoti, rikiuotis. $1991 \mathrm{~m}$. rugsèjo $8 \mathrm{~d}$. Karo muziejaus sodelyje įvyko ceremonialo atgaivinimo įžanga, buvo iškelta vẻliava, bet ne Vyčio Kryžiaus, o Vytauto Didžiojo. Šj sprendimą lèmè tai, kad tuo metu dar nebuvo Vyčio Kryžiaus kavalierių, o norèta pagerbti Vytauto Didžiojo vèliavą. Muziejaus darbuotojai rado šią seną vèliavą ir pagal ją pasiuvo naują. Kauno gyventojai surado plokštelę su įrašytu Karo invalidų maršu. Šauliams šis maršas buvo per lètas žygiuoti, nes buvo pritaikytas karo invalidams, todèl nutarta tempą pagreitinti.

Kai tik atsirado pirmieji Vyčio Kryžiaus kavalieriai, nuspręsta vèliavos pakèlimo ritualą atlikti kaip tarpukariu. Buvo peržiūrèta kino kronikų medžiaga, perskaityta daug ịvairių knygų ir straipsnių šia tema. Sunkiausia buvo rasti „pikių“ (iečių). Laimè, atsitiktinai muziejaus ginklų rinkinių saugykloje buvo rastos kelios aplaužytos ietys, tad reikejjo jas restauruoti. Tai padaryti pasisiūlè Marijampolès motodesantinio bataliono kariai, o Vyčio Kryžiaus vèliavą pasiuvo kaunietè Marija Ona Marcinkevičienè. Ceremonijai šauliai ruošèsi ilgai, jiems reikejjo žygiuoti ne tik su šalmais, bet ir su ietimis rankose. Šauliai repetavo ne vieną dieną ir tik po Kariuomenès dienos minejjimo suprato, kad galima sèkmingai žygiuoti, t. y. kad tai ne per sunku. Kaip prisimena Arvydas Pociūnas, šauliai net neįsivaizdavo, kad jie viską atliks taip gerai.

1994 m. lapkričio 23 d. ịvyko pirmoji tradicinè Vyčio Kryžiaus vèliavos pakèlimo ceremonija. Dalyvaujant kariuomenès vadui gen. mjr. Jonui Andriškevičiui, Šaulių sąungos Garbès būrys, vadovaujamas Vaidoto Bieliūno, tinkamai pražygiavo pro susirinkusiuosius, Vyčio Kryžiaus vèliavą pakèlè Vyčio Kryžiaus kavalierius plk. ltn. Saulius Veprauskas, Atskirojo jègerių bataliono vadas. Apie tai muziejaus istorikas Jonas Vaičenonis pasakojo: „Vaizdas buvo fantastiškas. Visi stovejo laimingi - vèl atgimè tarpukario Lietuvos tradicija... O šaulių veidai - koks pasididžiavimas jų akyse... Vyrai nusimetė metų naštą, atjaunėjo.“ (Karys, 1994 m. ) 
Pirmojoje ceremonijoje pasitaikè ir kuriozų. Norèdami, kad virš aukuro kiltų dūmai, organizatoriai panaudojo dūmini užtaisą. Bet stiprus rudens vẻjas dūmus nešè ị muzikantų pusę, jie pradèjo kosèti ir ašaroti. Daugiau tokių eksperimentų nebedarème, prisimena A. Pociūnas. Dabar aukure deginamos dujos. Tad jokių problemų nebekyla. Taip buvo atgaivinta tradicija, tęsiama ir dabar. Per valstybines šventes ir Kariuomenès dieną keliama Vyčio Kryžiaus vèliava. Žygiuoja aštuoni Šaulių sąungos Garbès būrio šauliai.

1998 m., minint Lietuvos kariuomenès atkūrimo 80-metị, Vytauto Didžiojo karo muziejuje buvo atkurta Žuvusiųjų kripta. Pagal likusius kelis artefaktus buvo atkurti lampionai, Vyčio kryžiai ir Vytis, o ant sienose imūrytų baltų marmuro lentų auksuotomis raidemis surašytos žuvusiųjų pavardès.

Keičiantis laikams keičiasi tradicijos, jos kuriamos dabartiniame muziejuje. Muziejus nuo 2006 m. pirmą kartą per gyvavimo metus pradejo leisti periodinị leidinị - Vytauto Didžiojo karo muziejaus almanachą, kuris dabar išeina kasmet. Jau išleista 10 žurnalų. Tai naujas reiškinys muziejaus istorijoje. Nuo 2007 m. muziejus dalyvauja Tarptautinės muziejų tarybos inicijuotame renginyje „Muziejų naktys“, kai muziejai visuomenei atveriami vakare ir nakti.

Šiuo metu muziejuje sukurtos šios naujos tradicijos: nuo $2014 \mathrm{~m}$. vyksta vadinamieji protų mūšiai, juose dalyvauja Lietuvos kariuomenès padalinių kariai, nuo 2015 m. - karinès dainos konkursas ir Kauno m. pradinių klasių moksleivių istorijos žinių konkursas „Mes - Lietuvos ateitis“. Rengiamos ịvairios Lietuvos karybos istorijai skirtos edukacinès programos muziejuje ir išvažiuojamosios, savaitgalio veiklos šeimoms.

Vytauto Didžiojo karo muziejaus išskirtinumą ir svarbą Lietuvos istorijoje rodo ir tai, kad Karo muziejuje lankydavosi Lietuvos prezidentai. Ši tradicija buvo pratęsta ir po Kovo 11-osios. Muziejui švenčiant savo jubiliejus, ị juos visada atvykdavo šalies prezidentas. $1996 \mathrm{~m}$. buvo švenčiamas pirmasis po sovietų okupacijos Vytauto Didžiojo karo muziejaus jubiliejus - 85-metis. Jame dalyvavo Lietuvos Respublikos prezidentas Algirdas Mykolas Brazauskas. Kas penkerius metus švenčiamuose jubiliejuose muziejų pagerbẻ kiti prezidentai: 2001 ir 2006 m. - Valdas Adamkus, 2011 m. - Dalia Grybauskaitè.

Tenka tik apgailestauti, kad šiuo metu atkurtos ne visos tradicijos, gimusios Pirmosios Respublikos laikais, ir ne visos šventès švenčiamos 
Vytauto Didžiojo karo muziejaus sodelyje. Keičiantis laikams, keičiasi ir renginių pobūdis, jų vietos ir rengejai. Tradiciškai muziejaus sodelyje minimos valstybinès šventės: Vasario 16-oji, Kovo 11-oji, Liepos 6-oji, Kariuomenès diena. Nauja tai, kad minima Sausio 13-oji ir $1941 \mathrm{~m}$. birželio 14 d. - trèmimų diena, rengiami šioms datoms skirti renginiai. Tačiau šių renginių organizatorius nèra Karo muziejus, jis tik aktyviai remia juos dalyvaudamas.

Lietuvos Respublikos krašto apsaugos ministro 2012 m. gruodžio 12 d. i̊sakymu Nr. V-1381 buvo patvirtinti muziejaus nuostatai, kuriuose apibrěžtas jo statusas ir veiklos kryptys: „Vytauto Didžiojo karo muziejus yra karo istorijos respublikinio muziejaus statusą turinti krašto apsaugos sistemos įstaiga, nesiekianti pelno, vieša, kaupianti, sauganti, tirianti, konservuojanti, restauruojanti, eksponuojanti ir populiarinanti muziejaus vertybes, atspindinčias Lietuvos valstybès kovas dèl laisvès ir nepriklausomybès, karų, kariuomenès ir karo meno istoriją, taip pat jų poveikį valstybès ir visuomenès raidai. "106 Laikydamasis šių nuostatu muziejus tęsia senąsias ir kuria naujas tradicijas, saugo turètus ir kaupia naujus eksponatus, pildo jais rinkinius, eksponuoja juos ekspozicijose ir parodose.

\section{IŠVADOS}

1. $1921 \mathrm{~m}$. ikurto Karo muziejaus tikslas buvo supažindinti visuomenę, kaip buvo kuriama Lietuva ir jos kariuomenè - kaip ji per amžius kovojo dèl savo valstybingumo. Tam tikslui, remiantis geriausiomis Europos muziejininkystes tradicijomis, buvo tiriama Lietuvos karo istorija, renkami karybos eksponatai, kuriami bataliniai paveikslai, rengiamos ekspozicijos. Muziejus turëjo dar vieną svarbų tikslą - auklèti visuomenę Tèvynès meilès dvasia. Tai buvo daroma rengiant patriotinius renginius ir įamžinant Lietuvai nusipelniusius asmenis. Buvo kuriamas panteonas - Karo muziejaus sodelis ir naujos tradicijos: Nežinomo kareivio pagerbimo ceremonijos, valstybinių švenčių ir Naujųjų metų šventimo, Vè-

\footnotetext{
${ }^{106}$ Lietuvos Respublikos krašto apsaugos ministro įsakymas „Dèl Vytauto Didžiojo karo muziejaus nuostatų patvirtinimo“, 2012 m. gruodžio 12 d., Nr. V-1381, Vilnius.
} 
linių minėjimo, žymių asmenų šarvojimo Didžiojoje salèje ir kt. apeigos. Tai rodo išskirtinị muziejaus vaidmenị Pirmosios Respublikos gyvenime ir jo nuopelnus auklejjant Lietuvos žmones tautiškumo ir meilès Tẻvynei dvasia. I šią muziejaus veiklą buvo įtraukta ir kariuomenè.

2. Pirmosios sovietinès ir nacių okupacijų metais labai didelès žalos muziejui nepadaryta, tačiau dalis tradicijų, susijusių su Lietuvos valstybingumu, buvo uždraustos. Per antrają sovietų okupaciją buvo sunaikinta ne tik Karo muziejaus ideja, jo kurtos tradicijos, ekspozicijos, bet ir dalis vertingiausių eksponatų: vieni buvo išvežti ị Vidaus reikalų ministerijos archyvą ir bibliotekų specialiuosius fondus, kiti - fiziškai sunaikinti. Nors naikinimas buvo totalus, Karo muziejaus sukurtas įvaizdis liko žmonių atmintyje. Sovietmečiu jis vis tiek buvo vadinamas ne Kariškai istoriniu (1940 ir 1945 m.) ar Kauno valstybiniu istorijos muziejumi (1956 m.), o Karo muziejumi. Tai leidžia daryti išvadą, kad Pirmosios Respublikos laikotarpiu Karo muziejus igyvendino savo tikslus ir puoselejo visuomenès istorinę atmintị, tad ji išliko gyva per visas okupacijas.

3. Prasidejus Atgimimui, muziejus vèl èmèsi igyvendinti atkuriamos valstybės idejąa. Nors tik dalis muziejaus darbuotojų aktyviai įsitraukè i Sąūužio veiklą, jų rengiamoms naujoms ekspozicijoms ir parodoms pritare ir kiti muziejaus darbuotojai bei administracija. Sąūdis paveikè visus ir ịtrauke ị atgimusios Lietuvos kūrimą. Muziejus buvo ta ịstaiga, kuri susigrąžino savo pavadinimą iki Kovo 11-osios ir aktyviai dalyvavo atkuriant muziejaus sodelị, prisidejo prie visuomenès atgimimo. Visos šventès ir atmintini renginiai vyko Vytauto Didžiojo karo muziejuje ir jo sodelyje.

4. Muziejaus vaidmuo išlieka svarbus ir dabar ne tik saugant sukauptus turtus, tęsiant atkurtas tradicijas, kuriant naujas ir pritaikant jas modernejjančiai visuomenei, bet ir aktyviai propaguojant karo mokslą, atskleidžiant kariuomenès svarbą Lietuvos istorijoje. 


\section{ŠALTINIAI IR LITERATŪRA}

\section{Šaltiniai}

Vytauto Didžiojo karo muziejus, Lietuvos valstybės centrinis archyvas, f. 1764, ap.1, f. R-423, ap. 1;

Kauno regioninis valstybės archyvas, f. 219.

Kariškai istorinio muziejaus einamųjų sąskaitų knyga. 1941-1942 m.

Vytauto Didžiojo karo muziejaus rinkiniai, Pagalbinis fondas.

Lietuvos kariuomenei ịsakymas Nr. 205, Kaunas, 1919 m. gruodžio 15 d.; ịsakymas kariuomenei Nr. 17, Kaunas, 1921 m. sausio 22 d.; įsakymas kariuomenei Nr. 10, Kaunas, 1922 m. vasario 14 d.; isakymas kariuomenei Nr. 276, Kaunas, 1921 m. lapkričio 28 d., \$1; Karo muziejaus statutas, iqsakymas kariuomenei Nr. 101, $\$ 3 ; 1934 \mathrm{~m}$. spalio 27 d. įsakymas kariuomenei Nr. 110, 1934 m. lapkričio 23 d.; isakymas kariuomenei Nr. 14, $1936 \mathrm{~m}$. vasario $29 \mathrm{~d}$.

Dèl „16 vasario“ šventès. Lietuva, Nr. 26, 1921 m. vasario $2 \mathrm{~d}$.

Dr. Basanavičius J. Iš Karo muziejaus istorijos. Mūsų žinynas, 1921 m., Nr. 21, p. 494.

Karo istorijos reikalu. Lietuva, 1922 m. vasario 16 d., Nr. 39.

Dr. J. Basanavičius, Iš Karo muziejaus istorijos (atviras laiškas valdžios ir Seimo atstovams). Lietuva, Nr. 236, 1924 m. spalio 18 d.

Laidotuvių gedulo apeigos. Lietuva, Nr. 42, $1927 \mathrm{~m}$. vasario $22 \mathrm{~d}$.

Kor. Spalių 9 d. minejjimas Karo muziejuje. Lietuva, Nr. 228, 1927 m. spalio $10 \mathrm{~d}$.

P. Respublikos Prezidento žodis (pasakytas atidengiant gegužès $14 \mathrm{~d}$. Laisvés paminklą Karo muziejaus sode). Lietuvos aidas, Nr. 86, 1928 m. gegužès. $18 \mathrm{~d}$.

Didžioji tautos šventè. Lietuvos aidas, Nr. 204, 1930 m. rugsèjo 9 d.

Klastingas lenkas savo sutartị sulaužè. Gen. Nagevičiaus kalba, atidarant „Juodąji paminklą“. Karys, Nr. 42, 1930 -Vytauto D. - m. spalio 16 d.

Liaudies vyriausybè pagerbė Nežinomo kareivio kapą. Lietuvos aidas, 1940 m. birželio 27 d., Nr. 301.

Padèka metalo aukotojams. Pavyzdinga Kauno Muziejaus vadovybès laikysena. I laisvę, 1942 m. gegužès 15 d., Nr. 113.

Tautos gedulo dienos - birželio $14 \mathrm{~d}$. - minèjimas Kaune. Ateitis, 
1943 m. birželio 15 d., Nr. 136.

Dariaus ir Girèno paminèjimas Karo muziejaus sodelyje. Ateitis, 1943 m. liepos 17 d., Nr. 164, p. 4.

Ištremtuosius prisimenant. Ateitis, 1944 m. birželio 15 d., Nr. 138.

Vèlinių proga buvo padèti vainikai ant Nežinomo kareivio kapo. Ateitis, 1944 m. lapkričio 3 d., Nr. 255, p. 5.

\section{Literatūra}

Butkus S. Ir mano Petras žygiuoja... Lietuvos karo invalidas, 1935, Nr. 1, p. 24.

Generolo gydytojo Vlado Nagiaus-Nagevičiaus gyvenimo ir darbų apžvalga. Klivlendas, 1962.

Jurevičiūtè A. Senojo muziejaus istorija 1919-1930 m. Vytauto Didžiojo karo muziejus 2006 metais, almanachas. Kaunas, 2007;

Jurevičiūtè A. Karo muziejaus vaidmuo kuriant švenčių tradicijas Kaune 1921-1930 m. Kauno istorijos metraštis, t. 9, Kaunas, 2008;

Jurevičiūtè A. Vytauto Didžiojo karo muziejus nacių okupacijos metais. 1941-1944 m. Kauno istorijos metraštis, t. 17, Kaunas, 2016.

Gečas S. Panteono atkūrimas. Vytauto Didžiojo karo muziejus 2010 metais, almanachas, Kaunas, 2011.

Iteikta $2019 \mathrm{~m}$. kovo $19 \mathrm{~d}$. 


\title{
VYTAUTAS THE GREAT WAR MUSEUM: CREATOR OF THE LITHUANIAN ARMED FORCES' TRADITIONS AND GUARDIAN OF MILITARY HERITAGE
}

\author{
Dr. Aušra JUREVIČIŪTE் \\ Vytautas the Great War Museum
}

Established in 1921, Vytautas the Great War Museum had a mission to introduce the society to the history of the development of Lithuania, its armed forces and fights for independent statehood. Following the best traditions of the European museology, the museum investigated the military history of Lithuania, collected military exhibits, drew battle pictures and arranged exhibitions. Additionally, the museum had yet another special mission, namely to educate the society in the spirit of love for the homeland. It was done through patriotic events and monuments for the Lithuanian heroes erected in the museum's garden, celebration of public holidays and New Year's Eve, marking All Saints' Day, wishing the dead farewell in the main hall, etc. It proves the museum's particular role in the life of the independent Lithuania and its merits in fostering national spirit and love for the homeland. The Lithuanian Armed Forces were effectively integrated in the activities organized by the museum. In 1930, a cornerstone was laid for a new museum building that was named in honour of the Lithuanian Grand Duke Vytautas, known as Vytautas the Great. The museum presented new exhibitions and a crypt honouring the dead unveiled in 1938, whereas a new tower boasted the first 35-bell carillon in Lithuania.

Of all the museums in Lithuania, Vytautas the Great War Museum suffered the most damage during the occupations. Its name was changed four times, while the exhibits were continuously destroyed by occupants. During the first Soviet and German occupation, the losses were not significant, however, some national traditions were banned. The second Soviet occupation destroyed the museum completely eliminating its traditions and exhibits. Nevertheless, the most valuable ones were transferred to the archives of the Ministry of the Interior and special funds of the libraries. 
Although the destruction was overwhelming, the museum remained alive in people's memory. In the Soviet period, the museum was called and known as the war museum despite its official names the Museum of Military History in 1940 and 1945 or Kaunas National Museum of History in 1956. It leads to the conclusion that due to the accomplished aims of the museum and cherished historical memory during the Independence period, it has endured throughout all the occupations.

When Sajüdis, the Reform Movement of Lithuania, began, the National Museum of History revived together with Lithuania. Prior to the declaration of the Act of Independence of Lithuania of 11 March 1990, the museum retrieved its initial name Vytautas the Great War Museum on 29 January 1990, actively restored its garden and made an important contribution to the revival of the state and society. Although only some employees of the museum got involved in the movement, the new exhibits and exhibitions they arranged awakened the society with the hidden and banned history. All the public holidays and celebrations were held at Vytautas the Great War Museum and its garden.

The role of the museum has remained significant to present day. Not only it preserves the museum treasures, but also collects the new ones, cherishes and establishes traditions and tailors them to the modern society. 